\title{
Evaluation of the
}

\section{Lead-Alpha (Larsen)}

Method for Determining

Ages of Igneous Rocks

GEOLOGICAL SURVEY BULLETIN 1097 - A

This report concerns work done in part on behalf of the U.S. Atomic Energy Commission and is published with the permission of the Commission

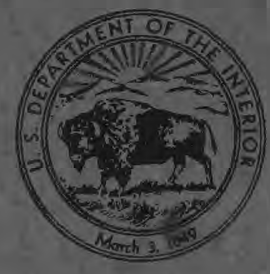





\section{Evaluation of the}

Lead-Alpha (Larsen)

Method for Determining

Ages of Igneous Rocks

By DAVID GOTTFRIED, HOWARD W. JAFFE, and FRANK E. SENFTLE

STUDIES IN GEOCHRONOLOGY

G E O L O G I C A L S U R V E Y B U L L E T I N 109 7-A

This report concerns work done in part on behalf of the U.S. Atomic Energy Commission and is published with the permission of the Commission

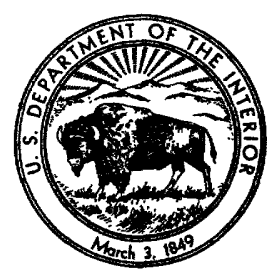


UNITED STATES DEPARTMENT OF THE INTERIOR

FRED A. SEATON, Secretary

\section{GEOLOGICAL SURVEY}

Thomas B. Nolan, Director 


\section{CONTENTS}

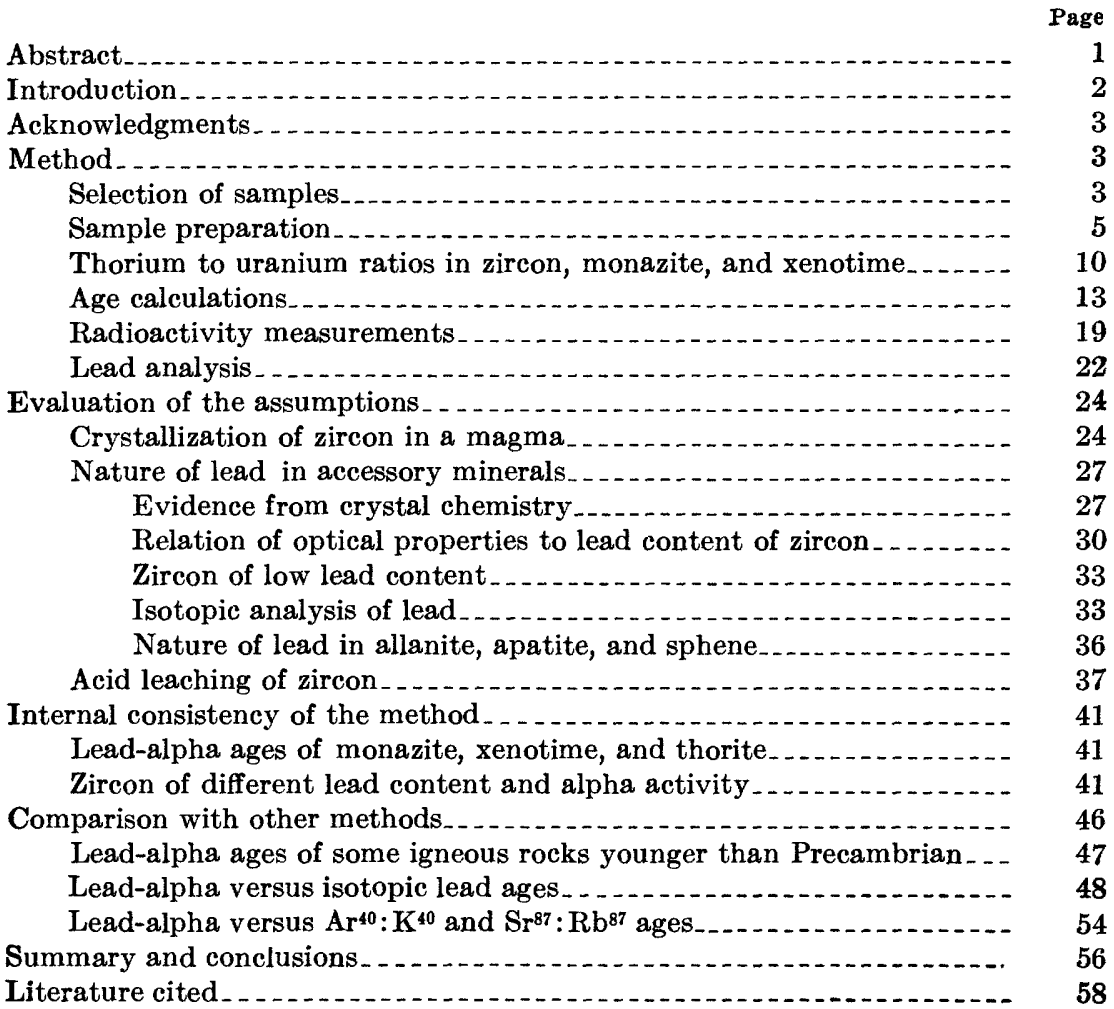

\section{ILLUSTRATIONS}

Plate 1. Zircon crystals from syenite, Lillian mine, Central City, Colo ........... Facing 54

Figdre 1. Variation of factor $c$ with the thorium-uranium ratio....... 15

2. Variation of the calculated age from the true age $\ldots \ldots \ldots$

3 . Variation of $k$ with the thorium-uranium ratio

4. Comparison of calculated and measured alpha activity for

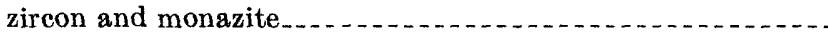

5. Index of refraction (omega) of Ceylon zircon and the relation to lead content.

6. Lead-alpha ages of accessory minerals from igneous rocks of known geologic age compared with Holmes' $B$ time scale... 


\section{TABLES}

TABLE 1. Thorium to uranium ratios in zircon

2. Thorium to uranium ratios in monazite.

3. Percent deviations from true age in the calculated age due to choice of factor $c$ for different thorium-uranium ratios......-

4. Constants for zircon, monazite, and xenotime used in age calculation

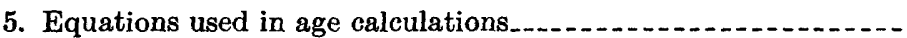

6. Comparison of alpha activities and conversion coefficients for zircon

7. Comparison of alpha activities and conversion coefficients for monazite . . . . . . .

8. Precision of duplicate spectrographic analyses of lead in zircon and monazite

9. Comparison of emission spectrographic lead determinations with those made by other analytical methods

10. Hafnium content, hafnium to zirconium ratio, and radioactivity of zircon from igneous rocks of the batholith of southern California.

11. Lead found in orthoclase, biotite, and in some igneous rocks from southern California and southwestern Colorado............

12. Data for Ceylon zircon.

13. Lead-alpha ages of zircon containing less than 10 ppm lead...-

14. Original.lead content of isotopically analyzed zircon .........

15. Original lead content of isotopically analyzed monazite.......

16. Comparison of lead-alpha ages of allanite, apatite, and sphene with zircon.

17. Lead-alpha ages of zircon before and after leaching with acids.--

18. Comparison of lead-alpha ages of monazite, xenotime, thorite, and zircon

19. Comparison of lead-alpha ages of zircon fractions of different radioactivity and lead content from the same rock..........

20. Comparison of lead-alpha ages of zircon fractions of different crystal size from the same rock ...........................

21. Lead-alpha ages of some igneous rocks younger than Precambrian

22. Comparison of lead-alpha ages with isotopic ages............ 


\title{
STUDIES IN GEOCHRONOLOGY
}

\section{EVALUATION OF THE LEAD-ALPHA (LARSEN) METHOD FOR DETERMINING AGES OF IGNEOUS ROGKS}

\author{
By David Gottrried, Howard W. Jaffe, and Frank E. Senfrtwe
}

\section{ABSTRACT}

The age of an igneous rock can be determined from the lead-alpha activity ratios of certain accessory minerals (zircon, monazite, xenotime, and thorite) provided that, (1) these minerals crystallized contemporaneously with the enclosing rock-forming minerals, (2) their lead is all of radiogenic origin formed by decay of uranium and thorium after formation of these minerals, and (3) they have neither lost nor gained parent or daughter products since the time of crystallization.

The largest single source of analytical error is in the lead analysis, particularly for minerals which contain less than $10 \mathrm{ppm}$ of lead. For zircon and other accessory minerals that contain more than $10 \mathrm{ppm}$ of lead the analytical precision is 4 to 10 percent of the mean of duplicate measurements. Comparisons between the alpha emission measured by thick source alpha counting and that calculated from quantitative determinations of the uranium and thorium content of zircon and monazite indicate that the alpha activity measurements have an accuracy of \pm 5 percent.

Where the method has been applied to a large number of samples of suites of igneous rocks younger than Precambrian, the scatter pattern of the age data is what would be expected from the experimental errors. In general, the standard deviation from the mean age is about 10 percent or less for minerals from suites of rocks older than Cretaceous. For younger rocks, which contain zircon with very low lead content, the standard deviation from the mean is considerably greater than 10 percent but is less than 10 million years. Inasmuch as zircon, monazite, and xenotime from the same rocks give ages which agree within limits of error of the method, it seems that the presence of common lead or the loss or gain of parent or daughter products do not contribute signifcantly to the errors in the age measurements of most of the rocks tested that were younger than Precambrian. Age determinations have been made on many geologically well dated rocks in order to test the validity of the method by use of geologic evidence. With few exceptions, the age data agree with the geologic sequence of events and with the Holmes' $B$ geologic time scale.

Lead-alpha ages are in good agreement with many of the ages determined by the lead isotope, $A r^{40}: K^{40}$, and $\mathrm{Sr}^{87}: \mathrm{Rb}^{87}$ methods on minerals from unmetamorphosed igneous rocks younger than Precambrian.. However, the agreement 
with other methods is poor for zircon from Precambrian rocks inasmuch as the lead-alpha age corresponds to the $\mathrm{Pb}^{208}: \mathrm{U}^{238}$ age which is commonly lower than the $\mathrm{Pb}^{207}: \mathrm{Pb}^{206}$ age and concordant $\mathrm{Ar}^{40}: \mathrm{K}^{40}$ and $\mathrm{Sr}^{87}: \mathbf{R b}^{87}$ ages on mica. When concordant lead isotope ages are obtained on Precambrian zircon, the leadalpha age will also agree within the limits of error of the method.

As yet no satisfactory explanation has been found for the wide discrepancies in the measured ages of Precambrian zircon, but it seems likely that lead has been lost by partial or complete recrystallization in response to metamorphic processes. Lead-alpha ages determined on metamorphosed igneous rocks will generally not correspond to the true age of igneous activity, but may approach the age of metamorphism.

\section{INTRODUCTION}

A method for determining the approximate age of accessory minerals of igneous rocks based on the ratio of total lead content to the measured alpha activity of the mineral has been described by Larsen, Keevil, and Harrison (1952). Their investigations showed that zircon was most suitable for age measurements. During the past few years extensive research has been done to test the precision, accuracy, and applicability of the method to zircon and other accessory minerals from igenous rocks varying greatly in composition, geologic occurrence, and age. Monazite, xenotime, and thorite seem to be as suitable as zircon for age work. Apatite, allanite, and sphene have given erratic results and seem to be unsatisfactory.

The lead-alpha age determined for the accessory minerals will be the age of the enclosing rock if the following conditions are satisfied: (1) The accessory minerals are contemporaneous with the other rockforming minerals, (2) all the lead in the accessory minerals has formed from the decay of the radioactive elements present at the time of crystallization of the mineral, (3) neither parent nor daughter products has been lost or gained since the time of crystallization of the accessory minerals. Thus, by measuring the amount of the parent radioactive elements (thorium and uranium) in the mineral, and the total amount of daughter element formed (total lead), the age of the rock can, subject to the above qualifying assumptions, be calculated. As the alpha radioactivity of the specimen is a function of the thorium and uranium content, it is convenient to use it as a measure of the parent elements. Thus, the rock age can be calculated, accepting the above assumptions, by merely measuring the total lead content and the alpha activity of a zircon sample separated from a rock. These measurements can be made rapidly and at relatively low cost.

The purpose of this paper is to describe in detail the method and techniques that have been used to obtain the lead-alpha activity ratios on the suitable radioactive accessory minerals; to compare the calculated ages with the geologic sequence of events, and with ages obtained 
by other physical methods; to evaluate the assumptions involved, and to point out the applicability and the limitations of the method.

Because of the nature of the assumptions inherent in the method and the greater uncertainty in the analytical data it should be stressed at the outset that the lead-alpha method is considerably less precise than any of the isotopic methods currently employed in age work. A single age measurement by the lead-alpha method may provide only a crude approximation of the true age of the mineral. Several age measurements on suites of the same or different minerals from the same geologic setting provide more information and are essential in evaluating the age results.

Probably the lead-alpha method will be most useful in providing rapidly a large number of age determinations on igneous rocks with sufficient accuracy to be useful in many geologic problems. Since the solution of many geologic problems is dependent on age determinations of many samples, the methods described and evaluated in this report can be of much help to geologists.

\section{ACKNOWLEDGMENTS}

The authors express appreciation to Prof. E. S. Larsen, Jr. for continuous guidance and encouragement in the work presented here. Prof. P. M. Hurley of the Massachusetts Institute of Technology gave considerable assistance with problems regarding alpha activity measurements. Dr. H. D. Holland of Princeton University kindly made available some zircons measured for their uranium and thorium content. We are grateful to Dr. George Tilton of the Carnegie Institution of Washington, Henry Faul of the U.S. Geological Survey, and Dr. L. T. Silver of California Institute of Technology for permission to use unpublished isotopic data on accessory minerals and for making possible interlaboratory checks on the same material. Many colleagues in the U.S. Geological Survey contributed samples for measurement and helpful discussions on geological interpretations. Lorin R. Stieff, Thomas W. Stern, E. S. Larsen 3d, and George Phair have given the authors many suggestions and assistance in the preparation of this report.

This work was done partly on behalf of the Division of Research of the U.S. Atomic Energy Commission.

\section{METHOD}

\section{SELECTION OF SAMPLES}

In developing and testing the lead-alpha method for determining the age of accessory minerals, a considerable amount of data has been obtained relative to the distribution and the nature of the accessory minerals in igneous rocks ranging widely in chemical composition and 
geologic setting. This information can be usefully applied to the sampling of rocks to be dated and has a bearing on the amount of time and effort required to obtain an age determination.

Zircon is more widespread in igneous rocks than any other accessory mineral suitable for lead-alpha age work. In most igneous rocks the zircon content ranges from 10 to $200 \mathrm{ppm}$. There is a general correlation between the quantity of zircon, the radioactivity of the zircon and the rock type containing the zircon. In a calc-alkalic batholith, the amount of zircon in gabbro is very small (a few parts per million) and the alpha activity very low. Tonalites and granodiorites contain about 100 to $200 \mathrm{ppm}$; the alpha activity of the zircon from granodiorites may be two to three times that of the zircon from tonalites. Granites commonly contain a small amount of zircon but the alpha activity of this zircon may be much greater than that of the zircon from the less siliceous rocks. Frequently granites contain zircon crystals that vary widely in alpha activity and on such rocks two or more age measurements should be made on separate zircon fractions that differ in their activity and lead content.

Monazite and xenotime occur principally in the late stage differentiates that usually contain garnet or muscovite or both. On a few occasions it has been possible to make age determinations on two or more minerals from the same or related rocks. Ages of monazite and xenotime are particularly desirable for very young rocks as these minerals are relatively high in alpha activity and lead content.

Fine-grained extrusive rocks, which range from quartz latite to rhyolite in composition, yield relatively small amounts of zircon and this zircon is usually low in alpha activity. Basaltic rocks contain insufficient amounts of zircon for such age determinations. The highly siliceous coarser grained rocks which are from stocks associated with a volcanic series generally have sufficient amounts of zircon. Several volcanic tuffs have also yielded sufficient amounts of zircon for such age determinations.

The rocks of the border zones of batholiths frequently show structural and textural features that may result from granulation and deformation taking place when the marginal facies of the batholiths were almost completely crystallized or at a much later time. Age determinations on minerals from such rocks should yield the time of rock formation if the structure is of protoclastic origin. If the structures were formed as a result of a much later period of dynamic metamorphism the lead-alpha ratio will record the time of metamorphism if the minerals have been completely recrystallized or if recrystallization is not complete, an age somewhere between the original crystallization of the mineral and the time of metamorphism.

The following points have, in general, been found useful in guiding the selection of rocks for age determinations, although the number 
and kinds of samples will vary with the nature of the geologic problem at hand:

1. The specimens should be as fresh as possible, and free of inclusions of older rock and sulfide minerals. Pyrite and molybdenite contain lead and concentrate with the zircon.

2. In an area containing a variety of intrusive rocks that seem to be comagmatic, rocks varying widely in composition should be selected in order to obtain suitable accessory minerals differing in alpha activity, lead content, and chemical composition.

3. In a volcanic series, the more siliceous rocks and associated coarser stocks should prove most suitable. Basalts contain insufficient zircon to yield enough for analysis.

4. To derive the necessary amount of accessories, at least 50 pounds of rock should be collected. About 100 milligrams of the mineral is required for an age determination. For gabbros 200 pounds may be needed to obtain the required amount of zircon.

5. Samples with textures and minerals of normal igneous rocks are most favorable. Minerals from some rocks of Precambrian age and from those with metamorphic textures may yield ages much younger than the age of their original crystallization.

\section{SAMPLE PREPARATION}

Generally, a sample of 50 pounds of rock is processed for recovery of the accessory minerals. Small chips are fed into a roller-type grinder for size reduction to a -60 mesh grain size. In order to avoid the risk of contamination from lead, specially prepared stainless steel sieves are used in place of the usual soldered brass variety. The sieves used are 36 inches long, 18 inches wide, and 3 inches deep, and are made by tacking stainless steel-wire screening to an unpainted wooden frame.

After the sample is sieved, the -60 mesh fraction is further processed; the +60 mesh fraction is reserved for additional material if needed. The -60 mesh fraction represents, on an average, about 50 to 75 percent of the rock and will contain virtually all of the zircon and other heavy accessory minerals. Experience has shown that the yield of heavy accessory minerals obtained from regrinding the +60 mesh fraction is negligible. Although the size of the accessory zircon crystals tends to increase with the grain size of the host rock, the zircon crystals of plutonic rocks, with the exception of pegmatite, are smaller than 60 mesh in about 90 percent of several hundred rocks processed in compiling this report. Usually, the zircon crystals are not broken in the grinding operation, but are sprung or "popped" out of the enclosing minerals as free, whole crystals.

$507200-59-2$ 
The -60 mesh fraction of the rock is then passed over a Wilfley wet shaking table for bulk removal of the light minerals, principally the feldspars and quartz. As the Wilfley table automatically deslimes the sample, the time-consuming process of hand sieving to remove the -325 mesh fines is avoided. Further, the Wilfley table has been effective in the recovery of -400 mesh zircon, normally discarded by dry sieving. It also has the advantages of speed and economy by eliminating the need for large amounts of bromoform.

The sample is passed over the Wilfley table twice. The first pass deslimes the sample and provides an efficient recovery of heavy minerals. The heavy-mineral concentrate is tabled a second time for a refinement of the concentrate. The table is efficient in recovering the heavy minerals (density $>3.0$ ) with the exception of micas, which concentrate with the quartz and feldspar. Representative fractions of the light minerals are reserved and can be purified for other types of work.

The heavy-mineral concentrate of the Wilfley table is dried and then passed through the Frantz separator in the vertical position with the vibrator removed, at a setting of 0.05 ampere for the rapid removal of magnetite. Repeated passes at increasing currents will remove virtually all the ferromagnetic minerals. The maximum setting of 1.5 amperes in the vertical position is equivalent to about 0.4 ampere on the Frantz separator set up in the normal horizontal position (cross slope $10^{\circ}$, longitudinal slope $10^{\circ}$ ) with use of the vibrator. This concentrates the zircon, with practically no loss, in the relatively small nonmagnetic fraction. If xenotime and monuzite are present, the vertical Frantz separation should be carried out to a maximum of 1.0 ampere to prevent their concentration in the magnetic fraction.

The nonmagnetic concentrate from the vertical Frantz separation, now weighing tens rather than hundreds of grams, is then separated successively in bromoform (density $=2.86$ ) and in methylene iodide (density $=3.3$ ). Ordinary Clerici solution, prepared from salts of thallous malonate and formate, should not be used for the separation of minerals on which lead-uranium determininations are to to be made. Both $\mathrm{Tl}^{+}$and $\mathrm{Pb}^{+2}$ have large ionic radii (1.49 and 1.32 $A$, respectively) and a close geochemical affinity in sulfides such as galena, from which thallium is recovered as a commercial byproduct of metallurgical processes. Clerici solution may therefore contain a large amount of lead, and represents a potential source of lead contamination. Although Clerici solution is inherently water-soluble, thallium has been detected in zircon concentrates that have been separated in it, even after treatment with nitric acid. This may result from the formation of a small amount of insoluble chlorides of thal- 
lium. A Clerici solution from which lead has been extracted by a chemical procedure is occasionally used for specialized separations that require a density of about 4.0. In general practice, however, bromoform and methylene iodide are the only heavy liquids required. The less expensive liquid, acetylene tetrabromide, is not used instead of bromoform because of its greater viscosity and higher toxicity. For a similar reason, as well as for economy, acetone rather than carbon tetrachloride is used exclusively for washing the concentrates. As a precautionary measure, heavy liquids used for separation of minerals for lead-alpha age work are not used for any other purpose. Acetone and methylene iodide contain very little lead as determined by analysis:

\section{acetone $<1 \times 10^{-8} \mathrm{~g} \mathrm{~Pb}$ per $\mathrm{ml}$ methylene iodide $<1 \times 10^{-8} \mathrm{~g} \mathrm{~Pb}$ per ml.}

The mineral fraction heavier than methylene iodide is then passed through the Frantz separator in the normal position at successive settings of 0.1 to 1.5 amperes, stepped-up 0.1 ampere per pass. Allowing for some variation in magnetic response because of mineral stain and compositional difference, the three minerals used for leadalpha age determinations will concentrate as follows:

Xenotime

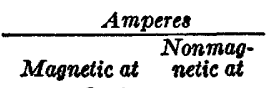

Monazite.

0.4

Fresh zircon

0. 5-0. 6

1. 5

Metamict varieties of zircon are extremely variable in magnetic response and may concentrate at settings ranging from 0.5 to $1.5 \mathrm{am}-$ peres. In addition to the current control, the longitudinal and cross slope may be varied to produce a different response to separation. Use of a virtually "flat" Frantz separator at maximum 1.5 amperes has given excellent results in separating slightly metamict zircon and rutile from fresh zircon.

The mineral fraction that is nonmagnetic at 1.5 amperes on the Frantz separator may contain minerals other than zircon. At this stage of separation the concentrate is composed of minerals having a density greater than 3.1 (allowing for some trapping of minerals whose density is near that of methylene iodide), and those that show no magnetic response up to 1.5 amperes on the Frantz separator. These may include apatite (especially the strontium or rare-earth rich varieties), barite, celestite, fluorite, pyrite, molybdenite, topaz, scheelite, zoisite, corundum, rutile, and more rarely, kyanite, sillimanite, cassiterite, and galena. On rare occasions, a totally nonmagnetic variety of sphene may concentrate with the zircon. Different procedures 
are required for the removal of the different minerals that concentrate with zircon so that each sample becomes a special job in mineral separation after the magnetic separation is completed. The different contaminating minerals are removed as follows:

Apatite.-This mineral has an average density of 3.18 and will normally float in pure methylene iodide (density $=3.3$ ). As most methylene iodide liquid media fall short of a density of 3.3 and as some apatites have a density above 3.18 when strontium, rare earths, and manganese are present in significant amounts, apatite may sink with zircon in methylene iodide. Even with careful stirring of the liquid, some apatite may be mechanically trapped by zircon grains during the separation. The authors removed apatite by leaching the concentrate in hot concentrated nitric acid for 15 minutes. The effects of acidleaching on zircon, monazite, and xenotime are elaborated under the section on "acid-leaching."

Pyrite.-This mineral, when fresh, is normally nonmagnetic and often concentrates with zircon. Nonmagnetic pyrite is commonly removed by leaching in hot concentrated nitric acid as described for apatite. A very efficient means of removing pyrite is by flotation in a small laboratory flotation cell.

Molybdenite.-This sulfide is particularly undesirable in the zircon concentrates because it often carries an appreciable amount of lead (about $1,000 \mathrm{ppm}$ ) ; it is a fairly common accessory mineral of granitic rocks. Although present in very small amounts in the rock, it may become abundant in the zircon fraction after many concentration procedures. A large part of the molybdenite can be removed by shaking the concentrate several times from one sheet of glossy paper to another. The molybdenite flakes will adhere to the paper as do the mica flakes. The concentrate is then leached in hot 1 to 1 aqua regia for about 15 minutes. Molybdenite is not as soluble as pyrite and will not dissolve in nitric acid alone.

Topaz, zoisite, fluorite, and corundum.-Although zoisite (density $>3.2$ ) and fluorite (density $=3.18$ ) will normally float in methylene iodide, they will occasionally sink for the reasons cited for apatite. Topaz (density $=3.58$ ) and corundum (density $=4.00$ ), however, are heavier than methylene iodide and are removed by separation in leadfree Clerici solution (density commonly adjusted to 4.1).

Barite and celestite.-Both sulfates are undesirable contaminants in the zircon concentrates and are difficult to remove. The similarity in the size and charge of the large divalent ions, $\mathbf{B a}^{+2}, \mathrm{Sr}^{+2}$, and $\mathrm{Pb}^{+2}$ (ionic radii $=1.43,1.27$, and $1.32 \mathrm{~A}$, respectively) indicates that lead may be expected to enter readily the lattice of either barite or celestite. Barite has also been reported to be radioactive owing to the presence of radium and its daughter products. Removal of barite from a 
zircon concentrate to be used for an age determination is therefore imperative. The density of barite (density $=4.5$ ) is so close to that of fresh zircon (density $=4.6$ to 4.7 ) that a density separation cannot be made. Flotation has not been tried and may prove successful. At present, barite is removed from zircon by a method developed by R. P. Marquiss (formerly of the U.S. Geological Survey). The concentrate is treated in a stoppered flask with a $2 \mathrm{~N}$ sodium carbonate solution kept under continuous agitation by use of a magnetic stirrer. Temperature is maintained at $90^{\circ} \mathrm{C}$. by means of an infrared lamp placed about 6 inches from the flask. After treatment with the sodium carbonate solution for 4 to 8 hours, the acid insoluble barium sulfate is converted to the carbonate which is dissolved readily by washing the sample in hydrochloric acid.

Of the heavy accessory minerals listed, only apatite and pyrite are commonly present in the zircon concentrate. For this reason the nitric acid leach has become a standard step in the purification procedure.

Following the acid leach, the zircon concentrate is carefully examined under both the binocular microscope and in oil immersions under the petrographic microscope. An immersion in an index liquid of 1.92 is most practicable, as the liquid will match the $\omega$ index of refraction of fresh zircon, and most impurity grains will show up with a marked negative relief. The zircon crystals are then spread out thin on a glass slide and any impurities are removed by suction with use of a glass tube attached to a laboratory vacuum hose (Senftle, 1951). The vacuum cleaning is carried out on several splits of zircon until a sample of $100 \mathrm{mg}$ of zircon is obtained. This final hand-picking operation is perhaps the most critical step in the mineral separation procedure, inasmuch as each grain is observed under the binocular microscope. No more than two samples per day should be handpicked due to the high element of fatigue involved which may result in carelessness. The final $100 \mathrm{mg}$ sample of zircon crystals used for the age determination must be closer to 100 percent than to 99 percent in purity. In practice, this is readily obtained for fresh zircons, with greater difficulty experienced with metamict and stained zircons, and those containing abundant inclusions. A systematic study of the inclusions in zircon and their possible relation to the common lead reported in some zircons, will require investigation by isotopic analysis. Generally, zircons with inclusions give the same age as zircons without inclusions separated from differentiates of the same batholith.

The handpicked sample of zircon is hand ground to a fine powder with a boron carbide mortar and pestle. The use of ordinary mortars may result in the addition of foreign lead in the sample. The mortar 
and pestle are cleaned with acetone between samples. As many zircons are zoned, the fine grinding will homogenize the sample to produce a more representative alpha count.

As many of the zircons examined for age determinations contain less than $10 \mathrm{ppm}$ lead, precautions must be taken to avoid laboratory contamination. No sample should be left uncovered on a sheet of paper for more than the time required for the separation procedure. Spectrographic analyses on material scraped from the Frantz separator showed the following lead content:

Scraping from the track

Parts per million

Paint on the magnet 10

Paint on the vibrator 500

A similar analysis made of laboratory dust collected over a period of time showed $1,000 \mathrm{ppm}$ lead, apparently contributed by old paint from pipes in the laboratory. Dust blown and circulated by laboratory air conditioners also represents a potential contamination hazard. Most of this hazard can be avoided by keeping all samples bottled except when they are actually being worked on.

\section{THORIUM TO URANIUM RATIOS IN ZIRCON, MONAZITE, AND XENOTIME}

A knowledge of the range of thorium to uranium ratios in the different accessory minerals is necessary in order to assign more accurate constants to the lead-alpha age equation and to the conversion factors which are used to correct the thick source alpha counts into units of thin source alpha counts. A compilation of the data from the more recent literature and some new data for zircon are given in table 1. Several independent methods have been applied to the measurement of the thorium and uranium contents of the minerals but rarely has the same material been analyzed by more than one method. The data obtained by isotope dilution analysis are probably accurate to \pm 1 percent (Tilton and others, 1955; Tilton, 1956). The expectable errors in the results obtained by the gamma-ray spectrometry method are discussed by Hurley (1956) and Hurley and Fairbairn (1957) and vary depending on the different proportions of uranium and thorium in the sample. For the samples that have been chemically analyzed for uranium and measured for alpha activity, the thorium content was calculated from the equation $\mathrm{Th}=\frac{\alpha-0.366 \mathrm{U}}{0.0869}$ where $\alpha$ is alpha activity per milligram per hour; $U$ the uranium content in parts per million and Th the thorium content in parts per million. Using this method the accuracy in the thorium to uranium ratios may be about \pm 20 percent. 


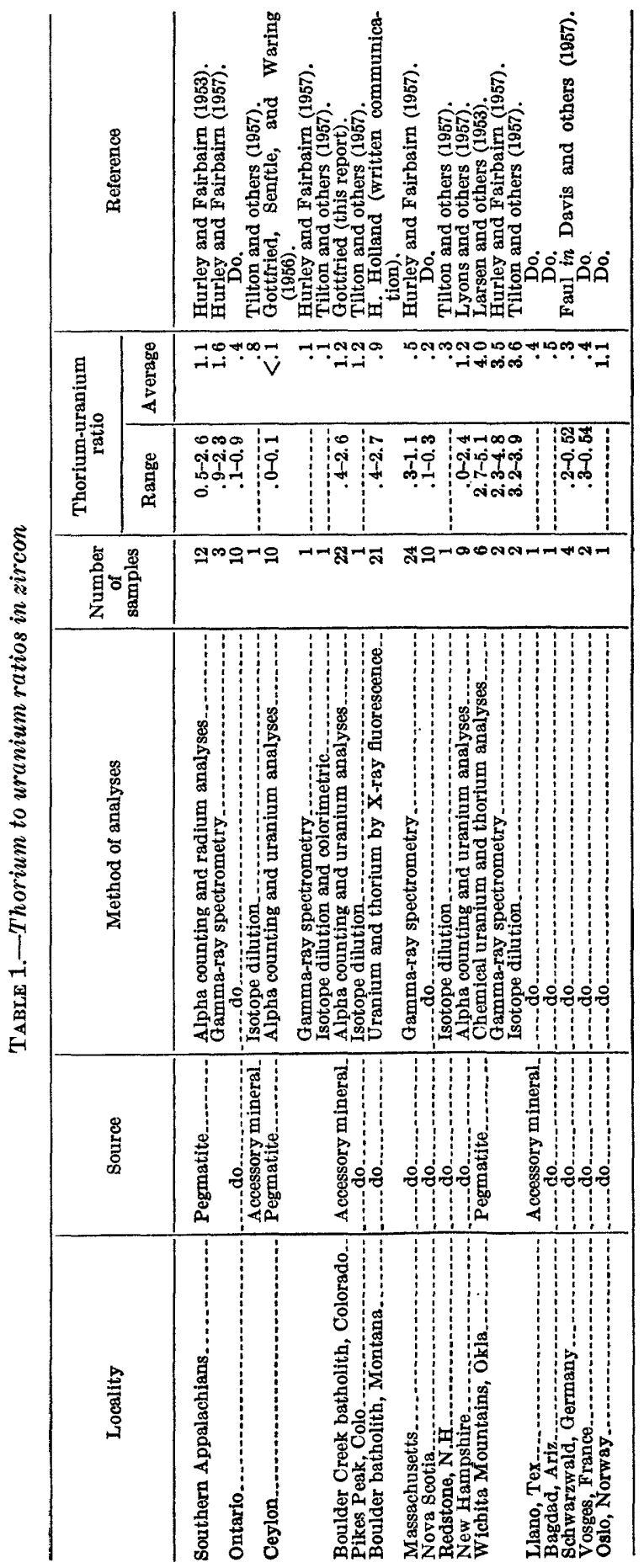


In zircon the thorium to uranium ratios show the greatest variation for samples of pegmatitic origin. The thorium-uranium ratios in the pegmatite zircon from Ceylon are less than 0.1 as determined by 3 different methods. Pegmatite zircons from Oklahoma have an average thorium-uranium ratio of about 4. The data on the zircon from the rocks of the Boulder batholith of Montana and the Boulder Creek batholith of Colorado should prove more typical of zircon from the average igneous rocks. These batholiths are composed of the ordinary calc-alkalic series of rocks which are similar to those forming the great batholiths of western North America. The thorium-uranium ratios of zircon from the Boulder batholith range from 0.4 to 2.7 and average 0.9 ; those from the Boulder Creek batholith range from 0.4 to 2.6 and average 1.1. For accessory zircon from rocks that are chiefly granite in composition Hurley and Fairbairn (1957) report an average thorium-uranium ratio of 0.4 , and for zircon of pegmatitic origin, a thorium-uranium ratio of 1.0. When more data become available on zircon from rocks of other petrographic provinces it may be possible to make fairly accurate estimates of the thorium-uranium ratios of zircon from a given series of rocks of a particular region. At present it seems reasonable to assign a thoriumuranium ratio of 1 for the average accessory zircon.

The thorium-uranium ratios for monazite (table 2) given in the literature are for the most part on samples of pegmatitic origin. From the data given in table 2 it seems that in general the highest thorium-uranium ratios are found in monazite derived from pegmatites or from deposits of unusual origin. The monazite from the unusual barite carbonate rock : from Mountain Pass, Calif., has an average thorium-uranium ratio of nearly 1,300. In pegmatitic monazite from other regions the average thorium-uranium ratio ranges from about 50 to 400 . For monazite occurring as an accessory mineral of ordinary granitic rocks, the thorium-uranium ratios are in general lower. The monazite of rocks from New England have an average thorium-uranium ratio of about 25 , and a similar ratio is found for monazite from the southern Appalachians, the placer concentrate from Idaho, and from a granite from the Grand Canyon in Arizona. A thorium-uranium ratio of only 2.5 was found in one sample of accessory monazite containing an unusually high content of uranium. As with zircon, most of the lead-alpha ages have been determined on accessory minerals from granitic rocks rather than from pegmatites. From sparse data an average thorium-uranium ratio of 25 has been assigned to accessory monazite of igneous rocks.

Xenotime is present in granitic rocks in much smaller amounts than either monazite or zircon. As a result no analyses for both uranium and thorium have been made on accessory xenotime from igneous rocks. Analyses of two samples of xenotime (Palache, Berman, and 
Frondel, 1951) of pegmatitic origin indicate that they contain more uranium than thorium. Thus an average thorium-uranium ratio of 0.5 is tentatively assigned to xenotime.

TABLE 2.-Thorium to uranium ratios in monazite

\begin{tabular}{|c|c|c|c|c|c|}
\hline \multirow{2}{*}{ Locality } & \multirow{2}{*}{ Source } & \multirow{2}{*}{$\begin{array}{l}\text { Num- } \\
\text { ber of } \\
\text { samples }\end{array}$} & \multicolumn{2}{|c|}{ Thorium-uranium ratio } & \multirow{2}{*}{ Reference } \\
\hline & & & Range & Average & \\
\hline Southern Appalach- & Saprolite... & 11 & $8-25$ & 20 & Mertie (1953). \\
\hline North Carolins......... & Pegmatite(?).... & 2 & $310-486$ & 398 & Holmes (1948a). \\
\hline & $\begin{array}{l}\text { Accessory } \\
\text { mineral. }\end{array}$ & 1 & & 2.5 & $\begin{array}{l}\text { W. C. Overstreet, U.S. Geol. } \\
\text { Survey (written commun- } \\
\text { cation, 1956). }\end{array}$ \\
\hline $\begin{array}{l}\text { New England } \\
\text { Portland Conn }\end{array}$ & Pegmatite & 10 & $13-75$ & $\begin{array}{r}25 \\
750\end{array}$ & Hurley and Fairbairn (1957). \\
\hline Colorado........... & A...do do & 1 & & 60 & $\begin{array}{l}\text { George Phair, U.S. Geol. } \\
\text { Survey (written communi- } \\
\text { cation). }\end{array}$ \\
\hline New Mexico. & - do do & $\begin{array}{l}1 \\
2\end{array}$ & $71-77$ & $\begin{array}{l}35 \\
74\end{array}$ & $\begin{array}{l}\text { Tilton and Nicolaysen (1957). } \\
\text { Holmes (1948a). }\end{array}$ \\
\hline Grand Canyon, Ariz.. & $\begin{array}{l}\text { Accessory } \\
\text { mineral. }\end{array}$ & 1 & & 25 & $\begin{array}{l}\text { L. R. Stieff and T. W. Stern, } \\
\text { U.S. Geol. Survey (written }\end{array}$ \\
\hline Manitoba, Canada..... & Pegmatite........ & 2 & $56-106$ & 81 & Holmes (1948a). \\
\hline $\begin{array}{l}\text { Northwest Territory, } \\
\text { Canada. }\end{array}$ & Placer........ & 1 & & 20 & $\begin{array}{l}\text { L. R. Stieff and T. W. Stern } \\
(\text { written communication, } \\
\text { 1956) }\end{array}$ \\
\hline California..... & Barite-carbon- & 2 & $1,280-1,325$ & 1,300 & Jaffe (1955) \\
\hline Idaho & Placer & 1 & & 24 & E. s. Larsen, Jr., U.S. Geol. \\
\hline & & & & & cation, 1956). \\
\hline Ontario, Canada. & Pegmatite........ & 1 & & $\begin{array}{l}23 \\
24\end{array}$ & $\begin{array}{l}\text { Hurley and Fairbairn (1957). } \\
\text { Holmes (1948a). }\end{array}$ \\
\hline Japan & ......do do... & 5 & $12-104$ & 80 & Do. \\
\hline South Africa...... & .......do... & 6 & $25-90$ & 48 & Tilton and Nicolaysen (1957). \\
\hline
\end{tabular}

\section{AGE CALCULATIONS}

The basic equations used for the age calculations are similar to those outlined by Keevil (1939). His age equations were presented in terms of the ratio of the total radiogenic lead to the thorium and uranium content. Thus, to calculate the age of an accessory mineral where the age is 300 million years or less, Keevil has shown that the age is given approximately by

$$
t=\frac{7.18 \times 10^{3} \mathrm{~Pb}}{\mathrm{U}+0.312 \mathrm{Th}}
$$

where $\mathrm{Pb}, \mathrm{U}$, and $\mathrm{Th}$ are the lead, uranium, and thorium contents of the mineral in parts per million and $t$ is the age in millions of years. The constants in this equation and throughout the paper have been recalculated from the following half-life data:

$$
\begin{aligned}
& T_{3 / 6}\left(\mathrm{U}^{238}\right)=4.51 \times 10^{9} y \\
& T_{3 / 6}\left(\mathrm{U}^{235}\right)=7.13 \times 10^{8} y \\
& T_{3 / 3}\left(\mathrm{Th}^{232}\right)=1.42 \times 10^{10} y \\
& T_{3 / 2}\left(\mathrm{Ra}^{226}\right)=1,622 y
\end{aligned}
$$


The lead is assumed to be the total radiogenic lead formed from the time of crystallization of the mineral without contamination with common lead.

The theoretical thin source alpha activity, $\alpha$ (in units of alphas per $\mathrm{mg}$ per hour) is given by

$$
\alpha=0.366 \mathrm{U}+0.0869 \mathrm{Th}
$$

Hence, the age, $t$, in terms of the alpha activity is

$$
t=\left[\frac{2,632+624 \mathrm{Th}: \mathrm{U}}{1+0.312 \mathrm{Th}: \mathrm{U}}\right] \frac{\mathrm{Pb}}{\alpha}=c \frac{\mathrm{Pb}}{\alpha}
$$

where $t$ is in millions of years, $\mathrm{Pb}$ is in parts per million, and $\alpha$ is the alpha activity given in equation (2).

Measurements of alpha activity may be obtained by thin-sourcecounting techniques (Keevil and Grasham, 1943). True thin sources, however, are difficult and time consuming to prepare, and the specific alpha activity is very low. For these reasons it is more desirable to use thick-source-counting techniques in the laboratory and, where necessary, convert the thick-source count ( $E$, in alphas per square centimeter per hour) to a thin-source count ( $\alpha$ in alphas per milligram per hour) by a suitable conversion factor.

Hurley and Fairbairn (1953) have calculated a conversion coefficient, $R=\frac{\alpha}{E}$, for zircon and obtain 0.493 assuming a thoriumuranium ratio of about 1 . Their calculation is based on a value of $\mu d=2.22 \times 10^{-3}$ derived from the Bragg-Kleeman law (Nogami and Hurley, 1948; Beharrell, 1949). The conversion coefficient can be obtained directly on accessory minerals that have been analyzed for thorium and uranium by calculating alpha from equation (2), and measuring the thick-source count experimentally. Column 7 , tables 6 and 7, shows the conversion coefficients obtained in this way for zircon and monazite. The value 0.496 compares well with that calculated for zircon by Hurley and Fairbairn. Conversion factors for other accessory minerals can be calculated in a similar manner.

The variation of the factor $c$ in equation (3) with the thoriumuranium ratio is shown in figure 1. It is obvious from the figure that the knowledge of an approximate value of the thorium-uranium ratio is necessary. If one chooses an average value for $c$ for a given mineral, some error will be reflected in the age due to deviations from the true thorium-uranium ratio. Table 3 shows the percent deviation in the calculated age from the true age for different thorium-uranium ratios due to a given choice of the factor $c$. For instance, in ordinary zircon the thorium-uranium ratio in most samples varies about a value of 1.0. It is rarely greater than 5 or less than 0.1 . Hence, by choosing $c=2,450$ one would not normally expect an error in age greater than 


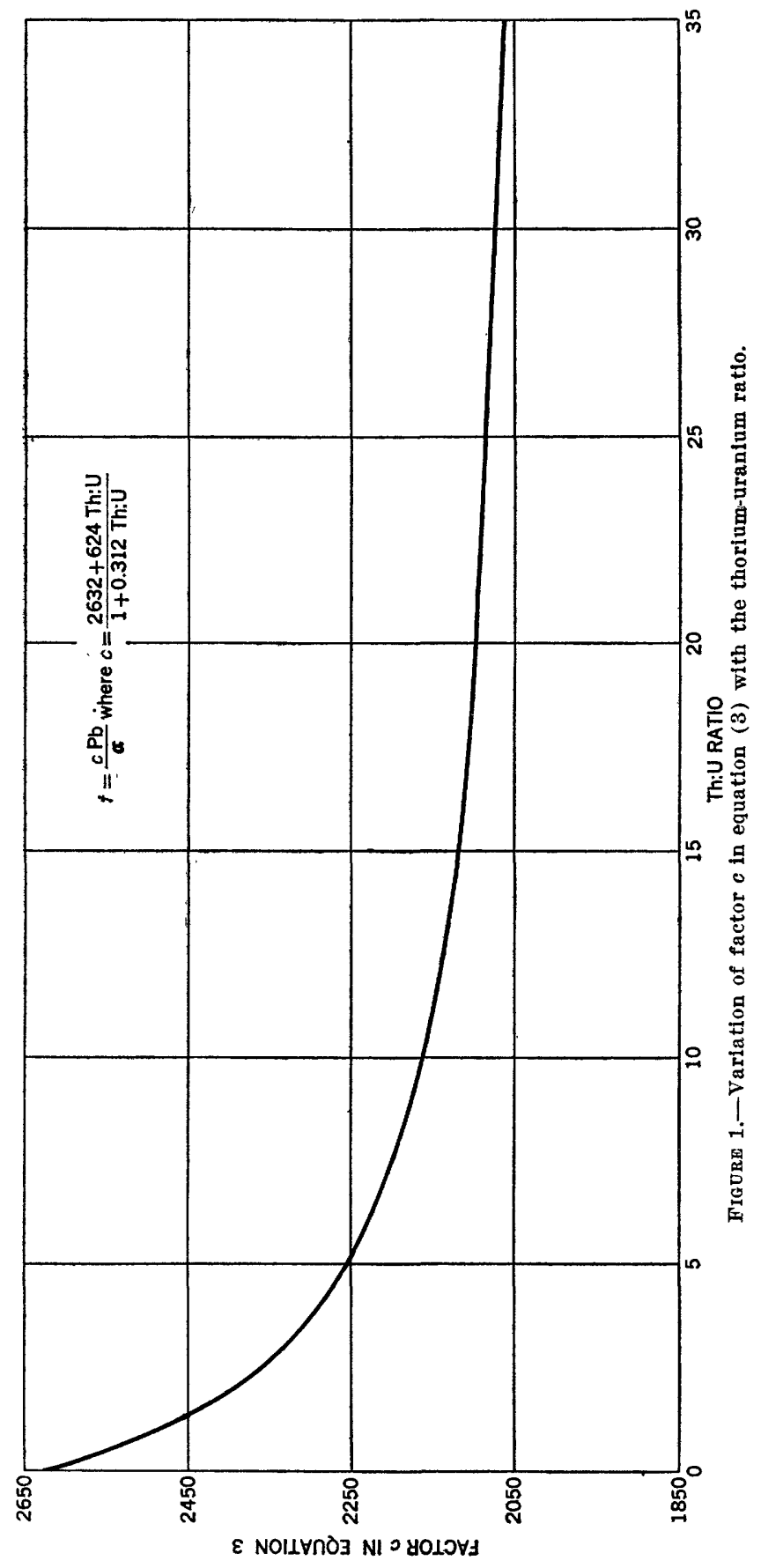


9 percent due to deviations from an assumed thorium-uranium ratio of 1.

Thus for an accessory mineral such as zircon, an approximate value for $c$ can be selected that will generally produce an error of less than 10 percent in the calculated age due to deviation of the thoriumuranium ratio from an assumed average. The $c$ factors suggested for use with some accessory minerals are shown in table 4.

TABLE 3.-Percent deviations from true age in the calculated age due to choice of factor $c$ for different thorium-uranium ratios

\begin{tabular}{|c|c|c|c|c|c|c|c|}
\hline & \multicolumn{7}{|c|}{ Thorium-uranium ratios } \\
\hline & 0.1 & 0.5 & 1.0 & 5 & 10 & 15 & 25 \\
\hline $\begin{array}{l}2,000 \\
2,050 \\
2,100 \\
2,150 \\
2,200 \\
2,250 \\
2,300 \\
2,300 \\
2,450 \\
2,500 \\
2,500\end{array}$ & $\begin{array}{l}-23.4 \\
-21.5 \\
-19.6 \\
-1.7 \\
-15.8 \\
-1.9 \\
-12.0 \\
-10.1 \\
-8.2 \\
-6.2 \\
-5.0 \\
-2.4\end{array}$ & $\begin{array}{r}-21.5 \\
-19.6 \\
-17.6 \\
-15.7 \\
-13.7 \\
-11.8 \\
-9.8 \\
-7.8 \\
-5.7 \\
-3.9 \\
-1.9 \\
0.0\end{array}$ & $\begin{array}{l}-19.5 \\
-17.5 \\
-15.5 \\
-13.5 \\
-11.4 \\
-9.4 \\
-7.4 \\
-5.4 \\
-3.4 \\
-1.4 \\
+0.6 \\
+2.6\end{array}$ & $\begin{array}{r}-11.4 \\
-9.1 \\
-6.9 \\
-4.7 \\
-2.5 \\
-0.3 \\
+1.9 \\
+4.2 \\
+6.4 \\
+8.6 \\
+10.8 \\
+13.1\end{array}$ & $\begin{array}{r}-7.6 \\
-5.3 \\
-2.9 \\
-0.6 \\
+1.7 \\
+3.9 \\
+6.3 \\
+8.6 \\
+10.9 \\
+13.2 \\
+15.5 \\
+17.8\end{array}$ & $\begin{array}{r}-5.7 \\
-3.4 \\
-1.0 \\
+1.3 \\
+3.7 \\
+6.0 \\
+8.4 \\
+10.7 \\
+13.1 \\
+15.4 \\
+17.8 \\
+20.2\end{array}$ & $\begin{array}{r}-4.0 \\
-1.6 \\
+0.8 \\
+3.2 \\
+5.3 \\
+8.0 \\
+10.4 \\
+12.8 \\
+15.2 \\
+17.5 \\
+19.9 \\
+22.4\end{array}$ \\
\hline
\end{tabular}

TABLE 4.-Constants for zircon, monazite, and xenotime used in age calculation

\begin{tabular}{|c|c|c|c|c|c|}
\hline Mineral & $\begin{array}{c}\text { Range of measured } \\
\text { thorium- } \\
\text { uranium ratios }\end{array}$ & $\begin{array}{l}\text { Selected } \\
\text { thorium- } \\
\text { uranium } \\
\text { ratio }\end{array}$ & & $c$ & $k \times 10-4$ \\
\hline $\begin{array}{l}\text { Zircon } \\
\text { Monazite } \\
\text { Xenotime. }\end{array}$ & $\begin{array}{l}0.1-5.0 \\
2.5-1,300 \\
2.2-1.0\end{array}$ & $\begin{array}{r}1.0 \\
25 \\
.5\end{array}$ & $\begin{array}{c}10.496 \\
1.392 \\
\text { ə. } 50\end{array}$ & $\begin{array}{l}2,485 \\
2,085 \\
2,550\end{array}$ & $\begin{array}{l}1.56 \\
.65 \\
1.71\end{array}$ \\
\hline
\end{tabular}

1 Experimental values.

2 Based on limited data.

Theoretical values.

Because of the gradual decay of the parent elements, the above equations are not strictly true for old minerals. In order to keep the error due to the decay of the parent element about the same as that in the constants previously discussed, that is, a fow percent, the approximate age equation (3) should not be used for minerals older than 200 million years. For instance, using equation (3), a 500 million year-old zircon with a thorium-uranium ratio of 1.0 will have a calculated age about 4 percent larger than the true age, and a 2,000 million-year-old zircon with the same thorium-uranium ratio will be in error by about 20 percent. (See figure 2.)

By expanding the exponentials in the fundamental age equation to the second term, Keevil (1939) has shown that a good approximate age 


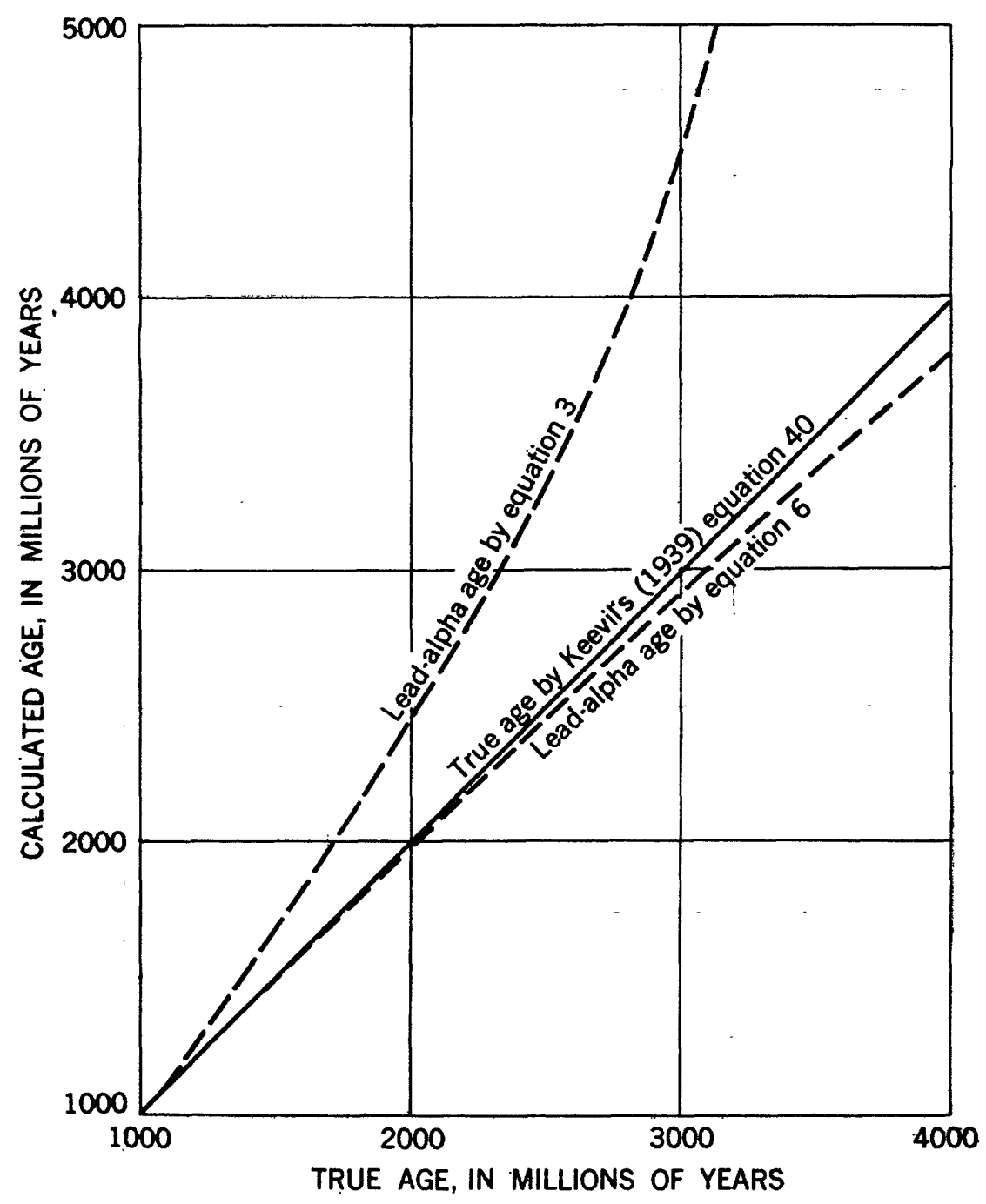

Figore 2.-Variation of the calculated age from the true age.

equation can be obtained for minerals up to 1,500 million years. This equation is:

$$
t_{0}=t-1 / 2 k t^{2}
$$

where $t$ is the age given by equation (3). The variation of $k$ with the thorium-uranium ratio is given in figure 3 and can be shown to be,

$$
k=\frac{77.2+6.20 \mathrm{Th}: \mathrm{U}}{4.06 \times 10^{11}(1+0.312 \mathrm{Th}: \mathrm{U})}
$$

Equation (4) is an extremely simplified equation; several approximations were made in its derivation. As Keevil has pointed out, 


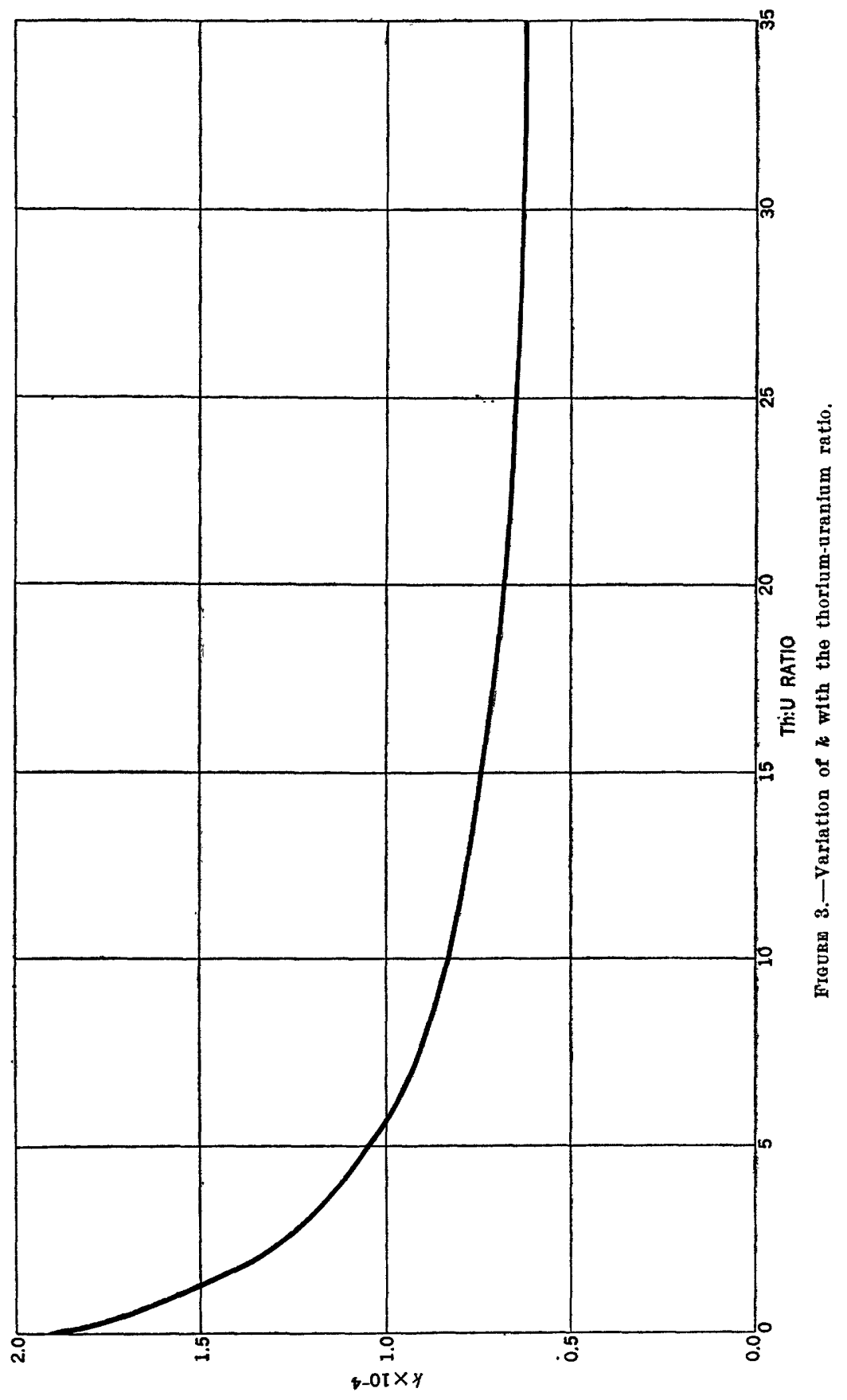


these approximations are such that the errors compensate to a great extent. For ages greater than about 700 million years the approximations used overcompensate and the equation gives ages which are lower than the true age. However, the correction is small, being less than 1 percent to as much as 1,700 million years. At 4,000 million years the correction amounts to about 5.5 percent (fig. 2). It can be shown that this error is approximately a function of $t_{0}{ }^{3}$ for ages less than 4,000 million years, and for the purpose of this work a correction can be most simply obtained by adding the term $+3.4 \times 10^{-9} t_{0}{ }^{3}$ to equation (4). Thus, for rocks older than 1,700 million years the age will be,

$$
T=\left(t-1 / 2 k t^{2}\right)+3.4 \times 10^{-9}\left(t-1 / 2 k t^{2}\right)^{3}
$$

More rigorous equations can be used to calculate the age of old rocks and minerals (Roques, 1956) but generally these are complicated and cumbersome to handle for routine work. Equations (3), (4), and (6) are preferable from the point of simplicity as well as being sufficiently accurate compared to the experimental data currently available for lead-alpha age calculations. Table 5 summarizes the equations that can be used depending on the approximate age of the mineral.

TABLE 5.-Equations used in age calculations

\begin{tabular}{c|l}
\hline $\begin{array}{c}\text { Range } \\
\text { (millions of years) }\end{array}$ & \multicolumn{1}{c}{ Equation } \\
\hline $0-200$ & $t=\frac{c \times P b(\mathrm{ppm})}{\alpha \operatorname{per~mg~per~hr}}$ \\
$\begin{array}{c}200-1,700 \\
1,700-4,000\end{array}$ & $\begin{array}{l}t_{o}=t-1 / 2 k t^{2} \\
T=\left(t-1 / 2 k t^{2}\right)+3.4 \times 10^{-0}\left(t-1 / 2 k t^{2}\right)^{3} \\
=t_{o}+3.4 \times 10^{-0} t_{o}^{3}\end{array}$ \\
\hline
\end{tabular}

\section{RADIOACTIVITY MEASUREMENTS}

The alpha activity is determined by counting with conventional ion chamber equipment and thick zircon sources. Small hemispherical chambers constructed with a drawer to admit the sample are the most suitable. The chamber is flushed with argon gas and the voltage is adjusted high enough to operate in the proportional region. Under these conditions, the background is generally less than 10 alpha counts per hour. Variations in the alpha count rates with a change in emanation of radon or thoron due to grinding has not been detected for zircon or monazite. Counting rates measured immediately after grinding showed no measurable difference from those measured several days after grinding. If an emanation effect is present, it must be small in these minerals.

The zircon is finely ground and placed in a sample dish, care being exercised to have the top surface as smooth as possible. The sample trays are circular, being about $1 \mathrm{~cm}$ in diameter and $0.1 \mathrm{~mm}$ deep, to 
insure a depth infinitely thick for the alpha particles. The top outer edges are beveled to facilitate cleaning off excess zircon powder when loading the trays. For samples of low radioactivity, it is sometimes desirable to use larger pans if sufficient sample is available. For such sample holders, it is difficult to consistently prepare samples with a smooth surface. A technique found useful in preparing smooth surfaces is to cover the roughly filled pan with a piece of glazed paper and carry out the final smoothing operation with a spatula on the top side of the paper cover. When the paper is removed a smooth surface results, which is suitable for alpha counting.

The data given in tables 6 and 7 show the comparison between the thin-source alpha activity calculated from the uranium and thorium content (column 5) with the value obtained by thick-source counting (column 6) and the conversion factor $R$ (column 7 ).

Using the average conversion factor, the calculated and measured alpha activities are plotted in figure 4. This figure indicates that

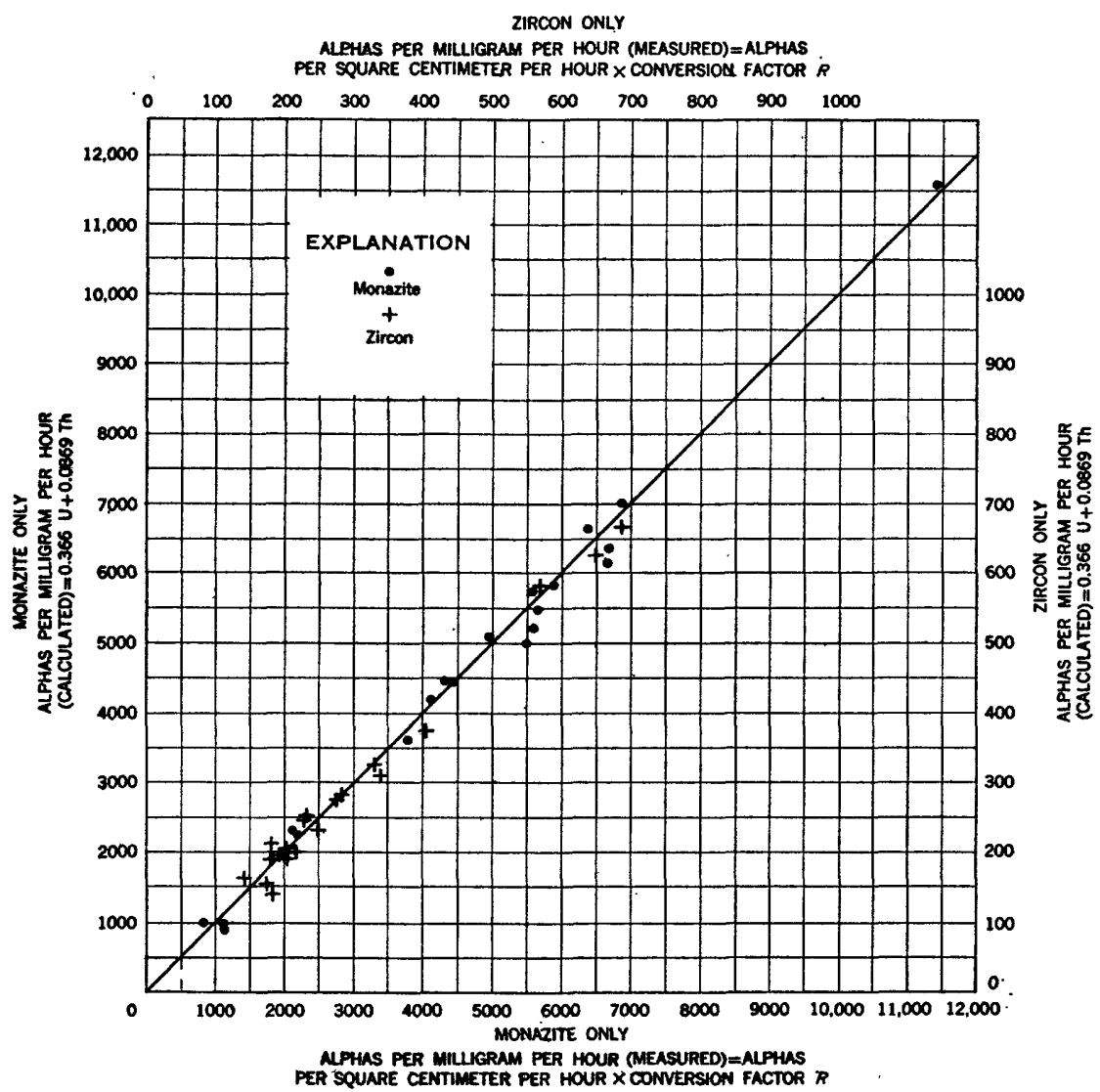

Figure 4.-Comparison of calculated and measured alpha activity for zircon (scale at right and top) and monazite (scale at left and bottom). 
TABLE 6.-Comparison of alpha activities and conversion coefficients for zircon

\begin{tabular}{|c|c|c|c|c|c|c|}
\hline Sample . & $\underset{\text { (ppm) }}{\text { Uranium }}$ & $\underset{(\mathrm{ppm})}{\text { Thorium }}$ & $\begin{array}{l}\text { Thorium- } \\
\text { uranium } \\
\text { ratio }\end{array}$ & $\begin{array}{c}\text { Alpha } 1 \\
(\alpha \text { per mg } \\
\text { per } \mathrm{hr})\end{array}$ & $\begin{array}{c}\text { E ( } \alpha \text { per } \\
\mathrm{cm}^{2} \text { per hr) }\end{array}$ & $R=\frac{\alpha}{E}$ \\
\hline 1 & 2 & 3 & 4 & 5 & 6 & 7 \\
\hline $\begin{array}{l}\text { BB-23 } \\
\text { BB-1 } \\
\text { BB-3 } \\
\text { BB-4a-4b } \\
\text { BB-5 } \\
\text { BB-66 } \\
\text { BB-7 } \\
\text { BB-15 } \\
\text { BB-17 } \\
\text { BB-18 } \\
\text { BB-20 } \\
\text { BB-21 } \\
\text { BB-22 } \\
\text { BB-24 } \\
\text { BB-25 } \\
\text { BB-27 } \\
\text { BB-28 } \\
\text { BB-233 } \\
\text { BB-344 } \\
\text { R-1932 } \\
\text { R-3185 } \\
\text { Z-22 }\end{array}$ & $\begin{array}{r}1,600 \\
755 \\
411 \\
479 \\
493 \\
450 \\
613 \\
575 \\
390 \\
319 \\
387 \\
330 \\
457 \\
1,430 \\
678 \\
617 \\
450 \\
517 \\
890 \\
670 \\
620 \\
460 \\
1.550 \\
2,650\end{array}$ & $\begin{array}{r}1,220 \\
611 \\
464 \\
335 \\
349 \\
328 \\
335 \\
412 \\
150 \\
276 \\
248 \\
890 \\
363 \\
1,215 \\
733 \\
639 \\
366 \\
507 \\
534 \\
904 \\
569 \\
400 \\
183 \\
2,180\end{array}$ & $\begin{array}{l}0.76 \\
.81 \\
1.1 \\
.70 \\
.71 \\
.73 \\
.55 \\
.72 \\
.39 \\
.87 \\
.64 \\
2.7 \\
.79 \\
.85 \\
1.1 \\
1.0 \\
.81 \\
.98 \\
.60 \\
1.3 \\
.92 \\
.87 \\
.12 \\
.82\end{array}$ & $\begin{array}{r}690 \\
329 \\
190 \\
204 \\
210 \\
193 \\
253 \\
246 \\
155 \\
140 \\
163 \\
198 \\
198 \\
627 \\
311 \\
281 \\
196 \\
233 \\
371 \\
323 \\
276 \\
202 \\
582 \\
1,059\end{array}$ & $\begin{array}{r}1,349 \\
663 \\
365 \\
408 \\
371 \\
414 \\
473 \\
467 \\
355 \\
316 \\
286 \\
412 \\
438 \\
1,043 \\
692 \\
572 \\
391 \\
503 \\
819 \\
706 \\
554 \\
412 \\
1,152 \\
2,109\end{array}$ & $\begin{array}{l}0.511 \\
.496 \\
.521 \\
.500 \\
.566 \\
.466 \\
.535 \\
.527 \\
.437 \\
.443 \\
.570 \\
.480 \\
.452 \\
.601 \\
.449 \\
.491 \\
.501 \\
.463 \\
.453 \\
.458 \\
.498 \\
.490 \\
.505 \\
.502\end{array}$ \\
\hline
\end{tabular}

1 Calculated from $\alpha$ per mg per $\mathrm{hr}=0.366 \mathrm{U}+0.0869 \mathrm{Th}$ (uranium and thorium in $\mathrm{ppm}$ ).

2 All samples prefixed BB analyzed by $\mathrm{H}$. Holland, Princeton University, by X-ray fluorescence.

Chemical analyses by F. Cuttitta, U.S. Geological Survey.

- Isoto pe dilution analyses by Tilton and others (1957).

TABLE 7.-Comparison of alpha activities and conversion coefficients for monazite

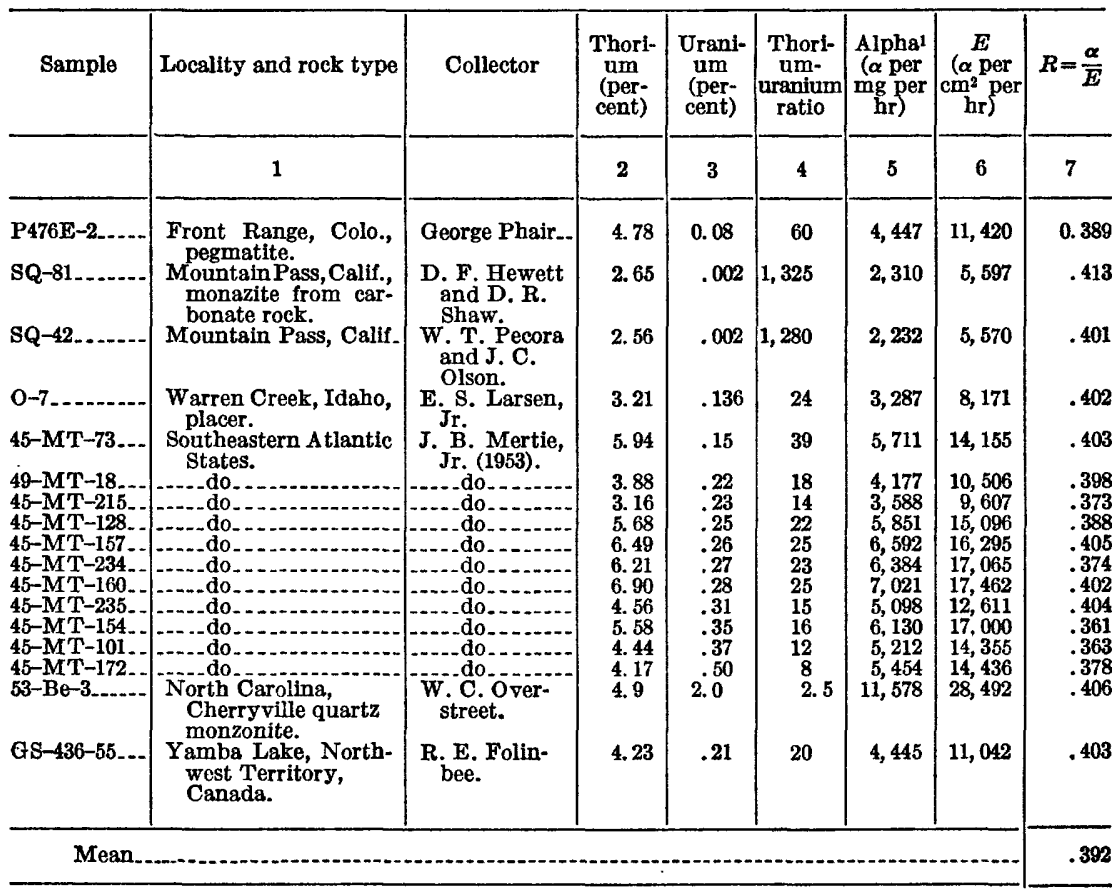

1 Calculated trom $\alpha$ per $\mathrm{mg}$ per $\mathrm{hr}=0.366 \mathrm{U}+0.0869 \mathrm{Th}$ (uranium and thorium in ppm). $507200-59-4$ 
the activity determined by counting methods agrees on the average within 5 percent with the alpha activity calculated from the thorium and uranium content. It also shows that the conversion factor is relatively independent of the thorium-uranium ratio over a wide range of activities. Experience has shown that the larger errors can be attributed to incorrect thorium or uranium determinations and possibly to a lesser extent to the effects of the thorium-uranium ratio on the conversion factor.

The ion chamber method of alpha counting of zircon is currently being used by the California Research Corp., Massachusetts Institute of Technology, and the U.S. Geological Survey laboratories, and a scintillation method is being used by Princeton University and Columbia University laboratories. In general, the interlaboratory checks agree within 5 percent. From these checks, and also from the alpha-counting experience in this and other laboratories, the alphacounting data probably are accurate to within 5 percent.

\section{IEAD ANALYSIS}

With further development of the lead-alpha method of age determination, an emission spectrographic method for the quantitative analysis of trace amounts of lead in accessory minerals was developed by Waring and Worthing (1953). They originally developed the method to cover a concentration range of 0.5 to $1,000 \mathrm{ppm}$ lead and have since extended the range to $3,000 \mathrm{ppm}$ lead (C. L. Waring, written communication). Lead is determined by direct current arc excitation of a $50 \mathrm{mg}$ sample consisting of $12.5 \mathrm{mg}$ of the mineral and 37.5 $\mathrm{mg}$ of lead-free sodium carbonate. The method as originally described (Waring and Worthing, 1953) used bismuth as an internal standard. Additional testing has shown that equal precision can be obtained without internal standards by exposing on the same plate as the mineral three or more external standards of known lead content; standards are selected to bracket the lead content of the mineral (C. L. Waring, written communication). Thus a curve for each plate is drawn showing the relations between blackening of the lead line $(2833.1 \mathrm{~A})$ and the lead content in the standards; from this curve the lead content of the mineral can be derived. The standards at present are prepared by diluting the National Bureau of Standards standard sample 91, opal glass, of known lead content, with lead-free quartz. These standards cover the range 0.5 to $933 \mathrm{ppm}$ lead.

Separate standards for the analysis of lead in monazite were prepared by adding lead to a cerium phosphate base material in concentrations that ranged from 1,000 to $3,000 \mathrm{ppm}$ lead. It was eventually determined that both the silica and cerium phosphate were equally satisfactory base materials for the preparation of standards 
for the analysis of lead in monazite (C. L. Waring, written communication, 1956).

The precision of the method was estimated by Waring and Worthing (1953) to be 6 to 10 percent of the mean on the basis of replicate analyses of a limited number of samples. Since 1953, duplicate lead analyses have been made on 279 samples of zircon with a lead concentration that ranged from 0.4 to $350 \mathrm{ppm}$ and 27 samples of monazite that contained from 25 to $2,000 \mathrm{ppm}$ lead. The precision for both minerals varies with the concentration of lead (table 8 ). The precision in table 8 is at the 90 percent confidence interval computed by using differences between duplicates as shown by Youden (1951). For further details of the method, the reader is referred to the paper by Waring and Worthing (1953).

The method has since been applied with satisfactory results by other investigators (Roques, 1956; Hée and Flesch, 1957; Saillard and others, 1957; and A. E. Stoddard, California Research Corp., written communication, 1956). Webber and others (1956) used an emission spectrographic method standardized by addition of known amounts of lead-barium glass to zircon. This calibration consistently yielded higher results than those obtained by Waring and Worthing. The lead-alpha ages reported by Webber and others (1956) were based upon lead analyses calibrated by standards used by Waring and Worthing.

TABLE 8.-Precision of duplicate spectrographic analyses of lead in zircon and monazite

\begin{tabular}{|c|c|c|}
\hline Number of duplicate anslyses & Lead range (ppm) & Precision (ppm) \\
\hline \multicolumn{3}{|l|}{ Zircon } \\
\hline 14 & $\begin{array}{l}0.5-2 \\
2-5 \\
5-20 \\
20-35 \\
35-100 \\
100-200 \\
200-350\end{array}$ & $\begin{array}{l} \pm 0.2 \\
\pm 1.0 \\
\pm 1.5 \\
\pm \\
\pm \\
\pm \\
\pm \\
\pm\end{array}$ \\
\hline \multicolumn{3}{|l|}{ Monazite } \\
\hline $\begin{array}{l}6 \\
6\end{array}$ & $\begin{array}{c}25-100 \\
100-500 \\
500-1,000 \\
1,000-2,000\end{array}$ & $\begin{array}{l} \pm 4.2 \\
\pm 7.0 \\
\pm 72 \\
\pm 80\end{array}$ \\
\hline
\end{tabular}

The chemical dithizone mixed-color method (Sandell, 1950) and its modification (Powell and Kinser, 1958) have been used to determine lead in accessory minerals. Powell and Kinser show a precision of \pm 1 
percent for lead in monazite. The isotope dilution method of analysis of lead in zircon, monazite, and other accessory minerals has been described by Tilton and others (1955). The isotope dilution method probably has an absolute error of less than 3 percent.

A comparison of lead analyses made by different methods on the same minerals is given in table 9. For the most part, the results are in good agreement. However, in several cases, notably samples 6-37, 44-MT-121, SQ-81, and F-22, the results are in disagreement by 75 to 300 percent; for each of these samples the emission spectrographic value is the lower. Half of the spectrographic lead values for the monazite from Mountain Pass were determined using the zircon standards and half using prepared cerium phosphate standards approximating the stoichiometric base composition of monazite. Both sets of data agree within 5 percent. Hence, base composition cannot be offered as an explanation for the disagreement with the higher values obtained by isotope dilution and modified colorimetric methods. The colorimetric method (Sandell, 1950) gave values still lower than the spectrographic method and showed good precision on any given day. Over a period of time, however, the content of lead determined colorimetrically varied about 30 percent of the mean (Jaffe, 1955). The results obtained by the colorimetric method of Sandell may be low because in the presence of large amounts of calcium and phosphorous some of the lead is carried down by insoluble phosphates to produce an incomplete dithizone extraction (Sandell, 1950).

Although most of the data obtained by different methods agree, the accuracy claimed for the chemical and spectrographic method does not always agree. Where errors occur, they may be large, even though high precision may be obtained. The sources of the errors in the cases considered have not been established. More research is being done on analytical problems connected with the samples that yield discrepant results.

\section{EVALUATION OF THE ASSUMPTIONS CRYSTALIIZATION OF ZIRCON IN A MAGMA}

A knowledge of the time of formation and the crystallization history of zircon in plutonic rocks is essential to a proper geologic interpretation of the lead-alpha ages. Zircon or other accessory minerals must have crystallized at the same time as the containing rock in order to have meaning in geochronologic dating. Although zircon has a wide distribution in a series of rocks of a calc-alkalic batholith, there is little agreement in the literature on the problem of whether zircon crystallizes with the early or later formed rocks during magmatic differentiation. 
TABLE 9.-Comparison of emission spectrographic lead determinations with those made by other analytical methods

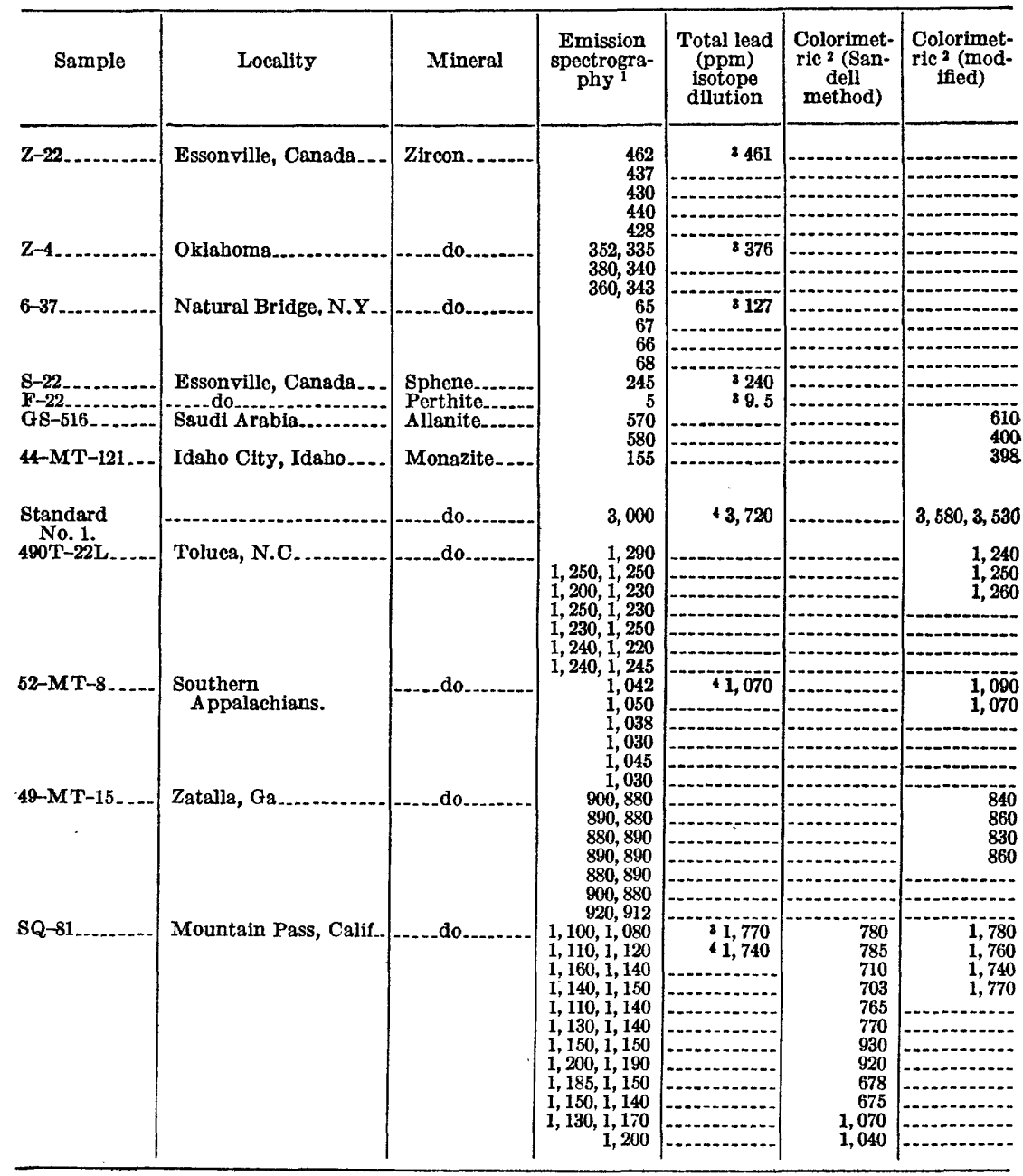

I C. L. Waring and H. W. Worthing, U.S. Geologleal Survey, analyste.

2 R. A. Powell, U.S. Geological Survey, analyst.

G. R. Tilton, analyst (Tilton and others, 1955 ; Waring and Worthing, 1953).

L. R. Stleff, U.S. Geological Survey, analyst.

If the time required for the emplacement and crystallization of a composite batholith is short (a few million years) it will make little difference whether zircon crystallizes early, late, or continuously. The difference between the time of crystallization of the accessory minerals and that of the major rock-forming minerals will be within limits of error of the lead-alpha method. Larsen (1945) has estimated that the time required for the crystallization of the batholith of southern California was on the order of a few million years. How- 
ever, on the basis of potassium-argon dating Evernden and others (1957) concluded that the time elapsed between the oldest and youngest intrusions of a series of igneous rocks that they dated from Yosemite National Park was 18 million years. In some areas and particularly in Precambrian terraines, rocks of igneous appearance may have been formed by complex metamorphic processes. Little is known regarding the time element involved in the formation of these rocks.

Poldervaart (1956) and Larsen and Poldervaart (1957) conclude that zircon crystallizes early in calc-alkalic rocks. Because of the uniformity of morphological features they believe that the zircon crystallized under uniform conditions which would most likely prevail for a short period of time during the early stages of crystallization of the magna. Moorhouse (1956) believes zircon crystallizes late on the basis of its textural relations to other minerals and the association of the zircon with late forming minerals. If the zircon forms early over a short range of crystallization, it is reasonable to assume that it would have uniformity in composition as well as size and shape. On the other hand, if zircon crystallizes continuously throughout differentitation the later formed zircon should be gradually enriched in uranium, thorium, and hafnium, which are progressively concentrated in the residual liquids. A study of the alpha activity, hafnium content, and hafnium to zirconium ratio on zircon separated from suites of calc-alkalic rocks has been undertaken to provide some information relative to this problem. Results of Gottfried, Waring, and Worthington (1956) on zircon separated from a suite of rocks from the batholith of southern California are given in table 10. These data show a progressive increase of hafnium and radioactivity in zircon from later formed rocks. This evidence indicates that zircon crystallizes continuously during the crystallization of the magma.

TABLE 10.-Hafnium content, hafnium to zirconium ratio, and radioactivity of zircon from igneous rocks of the batholith of southern California

\begin{tabular}{|c|c|c|c|c|c|c|c|}
\hline \multirow{2}{*}{ Rock type } & \multirow{2}{*}{$\begin{array}{l}\text { Number } \\
\text { of } \\
\text { samples }\end{array}$} & \multicolumn{2}{|c|}{ Percent hafnium 1} & \multicolumn{2}{|c|}{$\underset{\text { ratio }{ }^{1}}{\text { Hafnium-zirconium }}$} & \multicolumn{2}{|c|}{$\begin{array}{l}\text { Activity ( } \alpha \text { per } \\
\text { mg per hr) }\end{array}$} \\
\hline & & Range & $\begin{array}{l}\text { Aver- } \\
\text { age }\end{array}$ & Range & $\begin{array}{l}\text { Aver- } \\
\text { age }\end{array}$ & Range & $\begin{array}{l}\text { Aver- } \\
\text { age }\end{array}$ \\
\hline $\begin{array}{l}\text { Gabbro } \\
\text { Tonalite } \\
\text { Granodiorite } \\
\text { Quartz monzonite and granite. }\end{array}$ & $\begin{array}{l}1 \\
8 \\
6 \\
6\end{array}$ & $\begin{array}{r}0.97-1.12 \\
1.07-1.43 \\
.92-2.02\end{array}$ & $\begin{array}{l}1.0 \\
1.04 \\
1.21 \\
1.38\end{array}$ & $\begin{array}{l}0.021-0.024 \\
.023-.034 \\
.020-.042\end{array}$ & $\begin{array}{r}0.020 \\
.023 \\
.027 \\
.031\end{array}$ & $\begin{array}{l}143-594 \\
433-1,235 \\
396-4,660\end{array}$ & $\begin{array}{r}45 \\
256 \\
773 \\
1,586\end{array}$ \\
\hline
\end{tabular}

1 The values for the hafnium and hafnium to zirconium ratios are based on improved standardization techniques and thus differ from those reported by Gottfried, Waring, and Worthing (1956).

Because of the relatively high degree of stability of zircon, chemically and mechanically, as compared to most other minerals, relict 
zircon may be incorporated into a magma by assimilation or other processes. Unless the relict zircon has undergone complete recrystallization its age would be greater than that of the host rock. Twice thus far, it seems likely that relict zircon has been measured for age. An age of 460 million years was determined on zircon from a syenite from the border zone of the Idaho batholith. The syenite may be equivalent in age to the rocks from the main mass of the Idaho batholith whose mean age has been determined by Larsen and others (1958) as 108 million years by the lead-alpha method. Inclusions of amphibolite were present in the syenite and B. F. Leonard (written communication, 1956) has suggested it may have been contaminated by the Precambrian formations which the syenite intrudes.

In the La Sal Mountains of Utah, lead-alpha age determinations on zircon separated from three different samples of the diorite porphyry gave 380,410 , and 470 millions of years. The age of the diorite porphyry probably is Cenozoic on the basis of geologic field evidence. Abundant xenoliths of schist and amphibolite are in the outcrops of the diorite and according to C. B. Hunt and A. C. Waters, (Waters, 1955) the diorite magma was derived from partial fusion of Precambrian amphibolite. Lead-alpha ages of 50 and 24 million years, corresponding to Tertiary on the geologic time scale, were obtained on zircon from the monzonite and syenite porphyries which contain relatively few xenoliths. This age pattern may be explained on the basis of relict zircon in the diorite porphyry and predominantly magmatic or recrystallized zircon in the monzonite and syenite porphyries. However, until isotopic analyses of the lead in the zircon from the diorite porphyry are made the possibility of common lead in the zircon cannot be ruled out.

With the exception of the two examples cited, the good agreement between lead-alpha ages of zircon and the known geologic age of the rocks from different parts of the time scale indicate that in normal intrusive rocks the problem of relict zircon is not serious. Thus, with only a few exceptions, the assumption that the zircon is of the same age as the host rock seems valid.

\section{NATURE OF LEAD IN ACCESSORY MINERALS}

\section{EVIDENCE FROM CRYSTAL CHEMISTRY}

Larsen and others (1952) assumed that bivalent lead would not substitute for quadrivalent zirconium in the zircon lattice at the time of crystallization, and therefore they concluded that the lead in zircon was primarily all of radiogenic origin. This reasoning was based upon information pertaining to the mode of occurrence of lead in 
igneous rocks and on a comparison of the following ionic radii of Goldschmidt (1954) :

\begin{tabular}{|c|c|c|}
\hline Angstrom units & Angstrom units & $\begin{array}{r}\text { Angstrom units } \\
1.32\end{array}$ \\
\hline 1.05 & 1.18 & 1.33 \\
\hline 1.10 & 1.22 & $\mathrm{Sr}^{+2}$ \\
\hline $\mathrm{He}^{+4}$ & $\mathrm{Y}^{+3}$ & $\mathrm{Ca}^{+2}$ \\
\hline
\end{tabular}

According to Goldschmidt (1954) and Rankama and Sahama (1950), the lithophile lead in igneous rocks is present in silicate and phosphate minerals as $\mathrm{Pb}^{+2}$ ions. Because of the similarity of the ionic radii of $\mathrm{Pb}^{+2}, \mathrm{Sr}^{+2}, \mathrm{~K}^{+}$, and $\mathrm{Ca}^{+2}$, bivalent lead and strontium are captured mostly in potassium minerals such as feldspar and biotite and to a lesser extent in calcium minerals such as sphene, apatite, and augite. Goldschmidt (1954) reports 5 to $100 \mathrm{ppm}$ lead in potassium feldspar, 3 to $10 \mathrm{ppm}$ lead in augite, and as much as $50 \mathrm{ppm}$ lead in apatite. The data given in table 11 further illustrate the tendency of $\mathrm{Pb}^{+2}$ to concentrate in orthoclase and biotite of several igneous rocks. Larsen and Keevil (1947) have shown that lead concentrates in the most silicic magmatic rocks in the batholith of southern California because lead, potassium, and silica are progressively concentrated during magmatic differentiation. This is further borne out by the recent data of Wedepohl (1956) in a more detailed investigation of the geochemistry of lead. Tilton and others (1955) note in their detailed study of the lead, uranium, and thorium in a Precambrian granite from Ontario, that the nonradiogenic lead in the rock, indicated by the concentration of $\mathrm{Pb}^{204}$, resided principally in perthite and resisted strongly any tendency to concentrate in the zircon which contained none. They showed that uranium and thorium were highly concentrated in zircon, sphene, and apatite.

The data indicate, as would be predicted from principles of crystal chemistry, that $\mathrm{Th}^{+4}, \mathrm{U}^{+4}, \mathrm{Hf}^{+4}$, and $\mathrm{Y}^{+3}$ may substitute for $\mathrm{Zr}^{+4}$ in zircon on the basis of similarity of ionic radii. On the other hand, $\mathrm{Pb}^{+2}$ probably would not proxy for $\mathrm{Zr}^{+4}$ in zircon because of the large dissimilarity in ionic radii. The concentration of $\mathrm{Pb}^{+2}$ in potassium minerals where it substitutes for $\mathrm{K}^{+}$again reaffirms the principles of substitution based on similarity of ionic radii.

A comparison of sizes of the $\mathrm{Pb}^{+4}$ and $\mathrm{Zr}^{+4}$ ions shows a close similarity and the possible occurrence of $\mathrm{Pb}^{+4}$ ions in a magma must be taken into consideration. On the basis of ionization potentials Ahrens (1953) points out that $\mathrm{Pb}^{+2}$ is stable in most geologic environments as the ionization potential difference between $\mathrm{Pb}^{+2}$ and $\mathrm{Pb}^{+4}$ is large and that only under extreme oxidizing conditions would ionization produce the quadrivalent lead found in the mineral plattnerite $\left(\mathrm{PbO}_{2}\right)$. If 
such oxidizing conditions prevailed in a magma, it is highly probable on the basis of their oxidation potentials that nearly all the $\mathrm{Fe}^{+2}$ would be converted to $\mathrm{Fe}^{+3}$ before a significant part of the lead would become quadrivalent. Evidence for such oxidizing conditions is not found in normal igneous rocks.

Although the large $\mathrm{Pb}^{+2}$ ion probably would not proxy for $\mathrm{Zr}^{+4}$ in zircon, it might enter more readily the structure of monazite or xenotime substituting for the relatively large trivalent ions of the cerium group of rare-earth metals. Similarly, the ionic radii of $\mathrm{Th}^{+4}$ and $\mathrm{U}^{+4}$ are very close to those of the trivalent rare-earth ions and may more readily enter the lattices of monazite and xenotime than zircon. There is some evidence that $\mathrm{Th}^{+4}$ enters the lattice of monazite accompanied by $\mathrm{Si}^{+4}$ in a coupled substitution of $\mathrm{Th}^{+4} \mathrm{Si}^{+4}$ for $\mathrm{Ce}^{+3} \mathrm{P}^{+5}$, maintaining crystal neutrality (Jaffe, 1955). The ionic radii of the trivalent rareearth ions are given below :

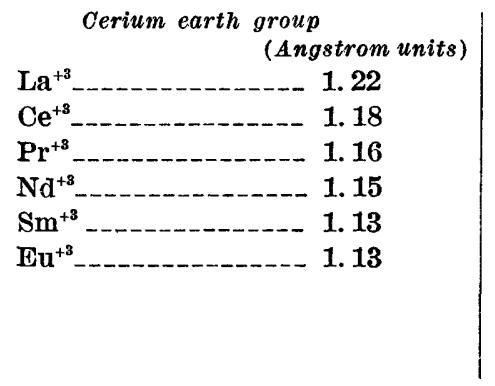

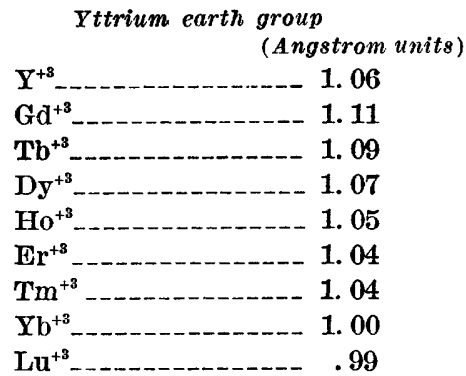

TABLE 11.-Lead found in orthoclase, biotite, and in some igneous rocks from southern California and southwestern Colorado

[Determined spectrographically by C. L. Waring, U.S. Geological Survey]

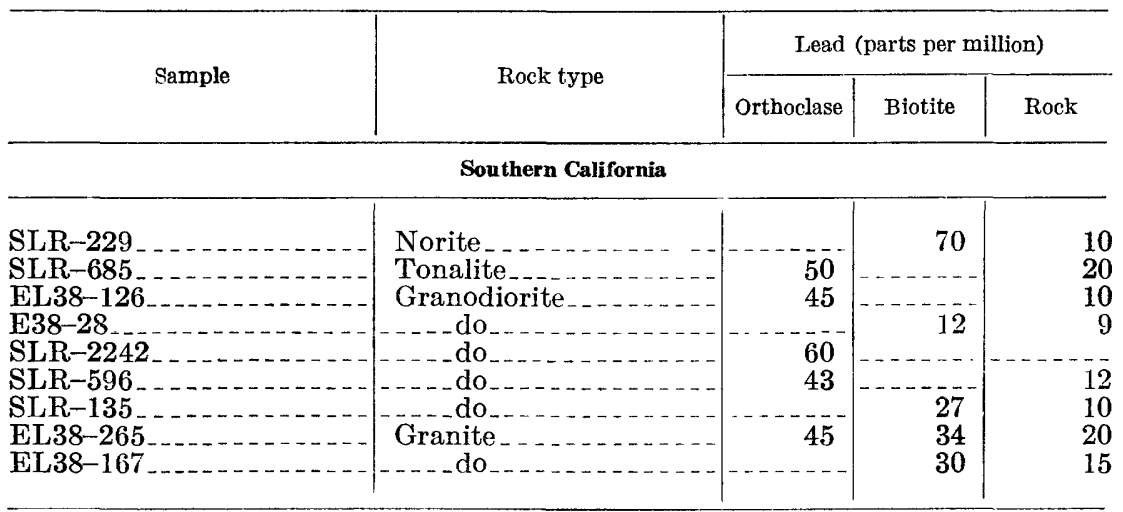

South western Colorado

Hinsdale formation 
The trivlaent ions of the cerium-earth group, characteristic of monazite, are larger than those of the yttrium-earth group characteristic of xenotime. Although this difference is not large, only relatively small percentages of the cerium-earth metals enter the structure of xenotime and similarly only minor amounts of the yttrium-earth metals enter the structure of monazite. Although the ionic radii of $\mathrm{Th}^{+4}$ and $\mathrm{U}^{+4}$ are similar, the larger ion, $\mathrm{Th}^{+4}$, follows the cerium-earth group in monazite and the smaller ion, $\mathrm{U}^{+4}$, follows the yttrium-earth group concentrating in greater amounts in xenotime. Thus, regarding monazite and xenotime, considerations of crystal chemistry suggest that greater amounts of original lead can be found in these two minerals than in zircon. However, the percentage of original lead of the total lead content is small owing to the formation of radiogenic lead from relatively large concentrations of uranium and thorium in monazite and xenotime as compared to zircon.

RELATION OF OPTICAL PROPERTIES TO LEAD CONTENT OF ZIRCON

Mineralogic and radioactivity studies of large clear unzoned crystals of zircon from Ceylon have shown that systematic relations exist between the changes in physical properties and the breakdown of the crystal structure due to alpha-particle bombardment. The nature of the processes involved have been treated in detail by Holland and Gottfried (1955) and the age of the zircon has been reported by Gottfried, Senftle and Waring (1956). According to the first report the indices of refraction of the zircon decreased as a function of the radiation dosage, that is, the alpha-particle emission rate times the age of the mineral. The same relation should exist between the optical properties and lead content if all the lead in the zircon is a function of the radioelement content and its age. However, if variable amounts of original lead were present in zircon no correlation would be found between lead content and any of the other physical properties, such as the indices of refraction and the density. With the optical method, the index of refraction, omega, can be measured rapidly, accurately, and on every grain, and only a relatively few grains are needed in an immersion for each determination. The data for the Ceylon zircon are given in table 12, and a plot of the index of refraction against lead content is given in figure 5. The curve obtained is of considerable interest and permits the following observations :

1. Zircon with less than $100 \mathrm{ppm}$ of lead has an index of refraction for that of normal zircon $(\mathrm{n}=1.92)$ and the curve is virtually flat.

2. As the lead increases beyond $100 \mathrm{ppm}$ the zircon shows a rapid decrease in the index of refraction, and at a concentration of 


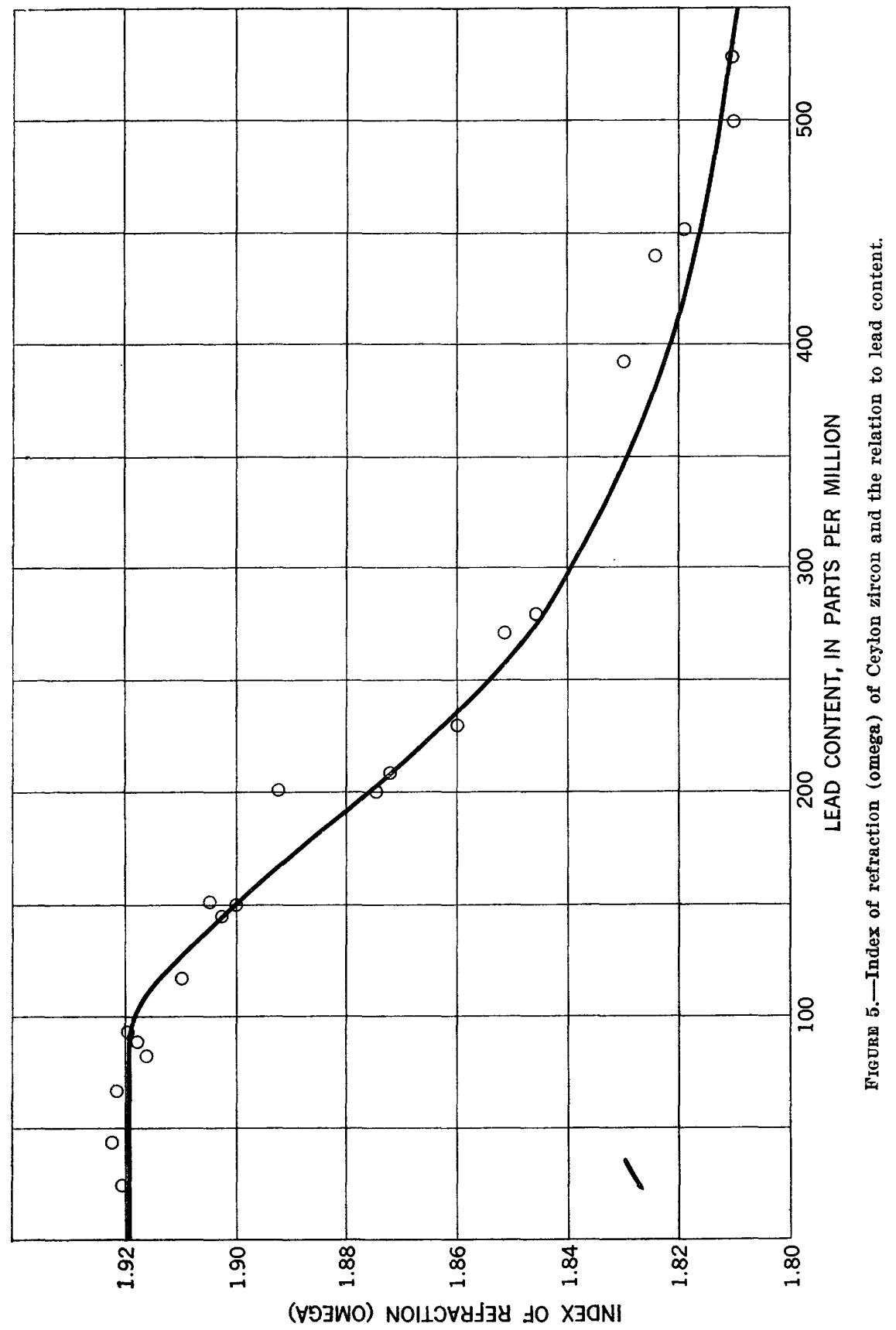


$500 \mathrm{ppm}$ of lead the zircon is practically isotropic with an index of refraction of 1.810 .

3. When more than $500 \mathrm{ppm}$ of lead are present the curve approaches the abscissa asymptotically.

TABle 12.-Data for Ceylon zircon

\begin{tabular}{|c|c|c|c|c|c|c|}
\hline \multirow{2}{*}{ Sample } & \multicolumn{2}{|c|}{ Index of refraction } & \multirow{2}{*}{$\begin{array}{l}\text { Specific } \\
\text { gravity }{ }^{1}\end{array}$} & \multirow{2}{*}{$\underset{(\mathrm{ppm})^{2}}{\text { Lead }}$} & \multirow{2}{*}{$\underset{\text { per } \mathrm{hr}}{\alpha \text { per } \mathrm{mg}}$} & \multirow{2}{*}{$\begin{array}{l}\text { Lead-alpha } \\
\text { age (mil- } \\
\text { lions of } \\
\text { years) }\end{array}$} \\
\hline & Omega & Epsilon & & & & \\
\hline 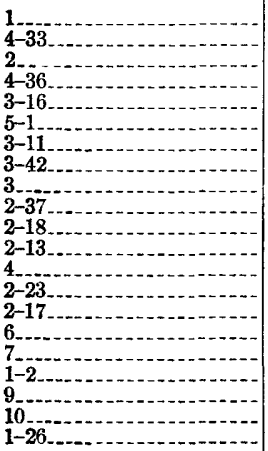 & $\begin{array}{l}1.921 \\
1.923 \\
1.922 \\
1.920 \\
1.916 \\
1.918 \\
1.910 \\
1.903 \\
1.905 \\
1.900 \\
1.893 \\
1.875 \\
1.872 \\
1.860 \\
1.852 \\
1.846 \\
1.830 \\
1.825 \\
1.819 \\
1.811 \\
1.810\end{array}$ & $\begin{array}{l}1.972 \\
1.978 \\
1.973 \\
1.965 \\
1.972 \\
1.958 \\
1.948 \\
1.932 \\
1.945 \\
1.923 \\
1.913 \\
1.886 \\
1.888 \\
1.870 \\
1.862 \\
1.855 \\
1.834 \\
1.828 \\
1.822 \\
1.813 \\
1.810\end{array}$ & $\begin{array}{l}\text { 4. } 680 \\
\text { 4. } 669 \\
4.653 \\
\text { 4. } 605 \\
\text { 4. } 593 \\
\text { 4. } 577 \\
\text { 4. } 550 \\
\text { 4. } 482 \\
\text { 4. } 440 \\
\text { 4. } 425 \\
\text { 4. } 421 \\
4.325 \\
\text { 4. } 279 \\
\text { 4. } 202 \\
\text { 4. } 165 \\
4.140 \\
\text { 4.048 } \\
\text { 4. } 029 \\
\text { 3. } 966 \\
\text { 3. } 965 \\
\text { 3. } 956\end{array}$ & $\begin{array}{r}22 \\
37 \\
65 \\
91 \\
80 \\
88 \\
115 \\
143 \\
150 \\
148 \\
200 \\
196 \\
205 \\
227 \\
270 \\
275 \\
392 \\
440 \\
450 \\
529 \\
498\end{array}$ & $\begin{array}{r}103 \\
150 \\
273 \\
430 \\
352 \\
380 \\
533 \\
649 \\
643 \\
652 \\
913 \\
850 \\
882 \\
985 \\
1,245 \\
1,185 \\
1,583 \\
2,040 \\
1,815 \\
2,197 \\
2,210\end{array}$ & $\begin{array}{l}\mathbf{5 3 2} \\
\mathbf{6 0 9} \\
\mathbf{5 9 0} \\
\mathbf{5 2 7} \\
\mathbf{5 6 5} \\
\mathbf{5 7 5} \\
\mathbf{5 3 6} \\
\mathbf{5 4 8} \\
\mathbf{5 7 8} \\
\mathbf{5 6 3} \\
\mathbf{5 4 5} \\
\mathbf{5 7 3} \\
\mathbf{5 7 6} \\
\mathbf{5 7 2} \\
\mathbf{5 3 8} \\
\mathbf{5 7 6} \\
\mathbf{6 1 3} \\
\mathbf{5 3 6} \\
\mathbf{6 1 3} \\
\mathbf{5 9 4} \\
\mathbf{5 6 0}\end{array}$ \\
\hline
\end{tabular}

$1 \mathrm{H}$. Holland, Princeton University, analyst.

2 C. L. Waring, U.S. Goological Survey, analyst.

In zoned zircon, the various zones differ in their optical properties and an average index of refraction is difficult to obtain. Usually the indices of refraction of the different zones can be directly measured along the edges of broken crystals. The area of each zone can be estimated and an approximation of the lead content of the zoned crystals can be obtained from the curve.

Although the curve is based entirely on unzoned zircon from Ceylon, the same relations were found for practically all zircons from the other localities. The high degree of correlation between the lead content and the index of refraction of many zircon samples, strongly suggests that nearly all the lead is of radiogenic origin.

Accordingly, an order of magnitude estimate of the lead content of zircon can be obtained by a knowledge of the index of refraction alone. This information is useful in the following respects:

1. It is possible when analyzing for lead in zircon by the spectrographic method (Waring and Worthing, 1953) to bracket zircon samples with suitable standards. In this manner lead analyses can be obtained in an initial attempt. Otherwise additional runs would be necessary which may not be possible when only a small amount of zircon is available.

2. When wide discrepancies have been found between the lead content determined from spectrographic analysis and the amount 
estimated, further work has revealed either an error in the analysis or the presence of previously undetected lead-bearing impurity grains other than zircon.

3. It is possible to estimate the amount of zircon required to insure extraction of a sufficient quantity of lead for isotopic analysis.

\section{ZIRCON OF LOW LEAD CONTENT}

The presence of original lead in zircon would have a maximum effect on the measured age of those zircons that contain little lead and low alpha activity To evaluate the age determined on such samples it is necessary that the geologic age of the parent rocks be accurately known from geologic evidence or from other independent methods. The igneous rocks of the San Juan Mountains of Colorado contain zircon low in lead and alpha activity, and the geologic ages of the rocks are Miocene and Pliocene. The lead content of these zircons range from 0.4 to $7 \mathrm{ppm}$ and the measured lead-alpha ages from 10 to 23 million years. Agreement between the geologic age and lead-alpha age has been obtained on zircon with low lead content (less than $10 \mathrm{ppm}$ of lead) from the well-dated igneous rocks of the Miocene age of Colorado, Oligocene age of New Mexico, Eocene age of Utah and Montana, Late Cretaceous age of Alberta, Canada, very late Cretaceous to very early Tertiary age of Montana, early Late Cretaceous age of Baja California, and the Middle to Late Devonian age of New Hampshire (table 13). It can be readily shown that the addition of as little as $2 \mathrm{ppm}$ of original lead of crystallization in zircon containing less than $10 \mathrm{ppm}$ lead would yield errors in the lead-alpha age from 500 percent in Miocene rocks to 25 percent in Devonian rocks. The fact that the lead-alpha ages of zircon from these rocks of known geologic age fall within limits of error in their proper sequence regardless of their lead content is convincing evidence that the problem of original lead contamination is negligible in most accessory zircon. If original lead is present in significant amounts it must be postulated that it has been deposited in quantities that were small and proportional to the amount of thorium and uranium in the zircon lattice at the time of crystallization.

\section{ISOTOPIC ANALYSIS OF LEAD}

The development of surface ionization techniques has made possible the isotopic analysis of small amounts of lead in zircon and other common rock-forming minerals. To date, most of the isotopic analyses of lead in zircon have been obtained by Tilton and others (1957) and by Henry Faul of the U.S. Geological Survey.

A tabulation of the data of Tilton and others (1957), Tilton (written communication, 1958), Faul in Davis and others (1957), and O. Kuovo (written communication, 1956) on the amount of original lead 
TABLE 13.-Lead-alpha ages of zircon containing less than 10 ppm lead

\begin{tabular}{|c|c|c|c|c|c|}
\hline $\begin{array}{l}\text { Rock type } \\
\text { Field No. } \\
\text { Locality } \\
\text { Collector }\end{array}$ & Mineral & $\begin{array}{l}\alpha \text { per } \\
\text { mg } \\
\text { per hr }\end{array}$ & $\begin{array}{l}\text { Lead } \\
(\mathrm{ppm})^{1}\end{array}$ & $\begin{array}{l}\text { Lead- } \\
\text { alpha age } \\
\text { (millions } \\
\text { of years) }\end{array}$ & Probable geologic age \\
\hline $\begin{array}{l}\text { Quartz latite porphyry...... } \\
\text { GL-8. } \\
\text { San Juan Mountains, } \\
\text { Summitville quad- } \\
\text { rangle, Colorado. } \\
\text { George Phair and David } \\
\text { Gottfried. }\end{array}$ & Zircon & 188 & $\begin{array}{l}0.7,0.8 \\
(0.75) \\
1.05 .1 .1 \\
(1.05)\end{array}$ & $\begin{array}{l}10 \\
11\end{array}$ & $\begin{array}{l}\text { Miocene (Larsen and Cross, } \\
\text { 1956). }\end{array}$ \\
\hline $\begin{array}{l}\text { Quartz latite, porphyry..... } \\
\text { GL-6. } \\
\text { San Juan Mountains, } \\
\text { Creede quadrangle, Colo- } \\
\text { rado. Phair and David } \\
\text { George Phair and } \\
\text { Gottfied. }\end{array}$ & -......... & 58 & $\begin{array}{r}0.4,0.6 \\
(0.5) \\
0.4\end{array}$ & 21 & Do. \\
\hline $\begin{array}{l}\text { Monzonite } \\
\text { RLS-1. } \\
\text { Cerrillos Hills, N. Mex. } \\
\text { R. L. Smith. }\end{array}$ & .............. & 770 & $\begin{array}{l}9,11 \\
(10)\end{array}$ & 32 & $\begin{array}{l}\text { Oligocene (post-Espinaso } \\
\text { volcanics, pre-Abiquiu(?) } \\
\text { formation) (Stearns, 1953). }\end{array}$ \\
\hline $\begin{array}{l}\text { Porphyritic potassic syenite... } \\
\text { P50-49. } \\
\text { Bearpaw Mountains, } \\
\text { Mont. } \\
\text { W. T. Pecora. }\end{array}$ & $\ldots$.......... & $\begin{array}{l}290 \\
275\end{array}$ & $\begin{array}{l}5.2,5.6 \\
(5.4) \\
5.0,5.1 \\
(5.05)\end{array}$ & $\begin{array}{l}46 \\
46\end{array}$ & $\begin{array}{l}\text { Middle Eocene (Green Riv- } \\
\text { er) (Brown and Pecora, } \\
\text { 1949). }\end{array}$ \\
\hline $\begin{array}{l}\text { Quartz monzonite, Silver City- } \\
\text { stock. } \\
\text { HTM-1. } \\
\text { Tintic district, Utah. } \\
\text { H. T. Morris. }\end{array}$ & $(\ldots+. . . . . .$. & $\begin{array}{l}187 \\
223\end{array}$ & $\begin{array}{l}3.7 \\
4.5\end{array}$ & $\begin{array}{l}49 \\
50\end{array}$ & $\begin{array}{l}\text { Middle Eocene (Green } \\
\text { River) (H. T. Morris and } \\
\text { T. S. Lovering, written } \\
\text { communication, 1956). }\end{array}$ \\
\hline $\begin{array}{l}\text { Kneehills tuff } \\
\text { 2415. } \\
\text { Alberta, Canada. } \\
\text { F. E. Folinsbee. }\end{array}$ & -........... & 268 & $\begin{array}{l}\text { 5. } 5,6.0 \\
(5.75)\end{array}$ & 53 & $\begin{array}{l}\text { Late Cretaceous (Maestrich- } \\
\text { tian) (Folinsbee and others, } \\
\text { 1957). }\end{array}$ \\
\hline $\begin{array}{l}\text { Quartz monzonite. } \\
\text { 52-C-10a. } \\
\text { Boulder batholith, Mont. } \\
\text { R. W. Chapman. }\end{array}$ & ................. & 160 & 4.6 & 71 & $\begin{array}{l}\text { Late Cretaceous to early } \\
\text { Tertiary (Laramide) } \\
\text { (Knopf, 1957). }\end{array}$ \\
\hline $\begin{array}{l}\text { Quartz monzonite } \\
\text { 52-C-60. } \\
\text { Boulder batholith, } \\
\text { Montana. } \\
\text { R. W. Chapman. }\end{array}$ & .............. & 203 & 6 & 73 & Do. \\
\hline $\begin{array}{l}\text { San Jose quartz diorite } \\
\text { BC-1-5. } \\
\text { San Jose pluton, Baja } \\
\text { California. } \\
\text { L. T. Silver. }\end{array}$ & $\ldots$.............. & 42 & $\begin{array}{l}1.8,2.0 \\
(1.9)\end{array}$ & 112 & $\begin{array}{l}\text { Early Late Cretaceous (post- } \\
\text { Albian, pre-Maestrichtian) } \\
\text { (Silver and others, 1956). }\end{array}$ \\
\hline $\begin{array}{l}\text { Quartz diorite. } \\
\text { SV-1. } \\
\text { San Vincente, Baja Call- } \\
\text { fornia. } \\
\text { David Gottfried, L. R. } \\
\text { Stieff, and T. W. Stern. }\end{array}$ & $\ldots$............ & 123 & $\begin{array}{r}5.1,5.0 \\
(5.05)\end{array}$ & 102 & Do. \\
\hline $\begin{array}{l}\text { Exeter diorite } \\
\text { NH-Edi-56J-18. } \\
\text { Exeter pluton, between } \\
\text { Exeter and Epping, } \\
\text { N.H. Jafie and J. B. } \\
\text { H. W. Jaffe } \\
\text { Lyons. }\end{array}$ & ......do...... & 75 & $\begin{array}{l}9,10 \\
(9.5)\end{array}$ & 307 & $\begin{array}{l}\text { Late Devonian(?) (post- } \\
\text { Eariy Devonian, pre-Mis- } \\
\text { sissippian(?) (Billings, } \\
\text { 1956). }\end{array}$ \\
\hline
\end{tabular}

1 The figure in parentheses is the average used in deriving the calculated ages. 
found in single zircon crystals and zircon concentrates is given in table 14. The data for the samples analyzed by Tilton indicate that the original lead content is less than 10 percent of the total lead present in 17 of the 20 samples. Of these, 14 samples showed only negligible amounts of original lead. The zircon concentrates from Capetown, South Africa, and Quartz Creek, Colo. contained 21 and 26 percent original lead, respectively. Two concentrates of zircon from the Bodom granite and Rapakivi granite of Finland contained no detectable original lead.

TABLE 14.-Original lead content of isotopically analyzed zircon

\begin{tabular}{|c|c|c|c|c|c|}
\hline \multirow{2}{*}{ Locality } & \multirow{2}{*}{ Rock type } & \multirow{2}{*}{$\begin{array}{l}\text { Total lead } \\
\text { (ppm) }\end{array}$} & \multicolumn{2}{|c|}{ Original lead } & \multirow[b]{2}{*}{ Reference } \\
\hline & & & $\begin{array}{c}\text { Parts per } \\
\text { million }\end{array}$ & Percent & \\
\hline Redstone, N.H.. & Granite...- & 32.5 & $\leqq 0.4$ & $<1.2$ & Tilton and others \\
\hline Ceylon & Pegmatite........ & 127 & $\leqq 1.7$ & $<1.3$ & Do. \\
\hline Tory Hill, Ontario & Granite............. & 461 & $\leqq 5.5$ & $<1.2$ & Do. \\
\hline $\begin{array}{c}\text { Cardiff uranium mine, On- } \\
\text { tario. }\end{array}$ & $\begin{array}{l}\text { Syenite } \\
\text { Pegmatite............ }\end{array}$ & $\begin{array}{l}123 \\
485\end{array}$ & $\leqq 1.5$ & $<1.2$ & $\begin{array}{l}\text { Do. } \\
\text { Do. }\end{array}$ \\
\hline $\begin{array}{l}\text { Llano, Tex } \\
\text { Natural Bridge, N.Y }\end{array}$ & Granite & $\begin{array}{l}53.8 \\
127\end{array}$ & $\begin{array}{l}\ 0.6 \\
\leqq 1.6\end{array}$ & $<1.1$ & $\begin{array}{l}\text { Do. } \\
\text { Do. }\end{array}$ \\
\hline Wichita Mountains, Okla... & Pegmatite, sample A.- & 63.5 & 2.6 & $\begin{array}{l}4.1 \\
8.8\end{array}$ & Do. \\
\hline $\begin{array}{l}\text { Pikes Peak, Colo } \\
\text { Bagdad, Ariz } \\
\text { Capetown, South Africa. } \\
\text { Quartz Creek, Colo } \\
\text { Marrs }\end{array}$ & $\begin{array}{l}\text { Granite } \ldots \text { do } \\
\text { do }\end{array}$ & $\begin{array}{l}33.3 \\
338 \\
66.5 \\
210\end{array}$ & $\begin{array}{r}3 \\
40 \\
14 \\
54\end{array}$ & $\begin{array}{l}9 \\
11.5 \\
21 \\
26\end{array}$ & $\begin{array}{l}\text { Do. } \\
\text { Do. } \\
\text { Do. } \\
\text { Do. }\end{array}$ \\
\hline Marys kock Tunnel, va.... & Granodiorite gneiss..... & 82.6 & $<1.0$ & $<1.2$ & $\begin{array}{l}\text { G. R. Tilton } \\
\text { (written com- } \\
\text { munication, } \\
\text { 1958). } \\
\text { Do. }\end{array}$ \\
\hline $\begin{array}{l}\text { Towson dome, Baltimore, } \\
\text { Md. }\end{array}$ & wille-- & 65 & $<1.0$ & $<1.5$ & Do. \\
\hline $\begin{array}{l}\text { Phoenix dome, Baltimore, } \\
\text { Md. }\end{array}$ & -...do...... & 104 & $<1.5$ & $<1.4$ & Do. \\
\hline $\begin{array}{l}\text { Canada Hill, N.Y } \\
\text { Philadelphia, Pa } \\
\text { Storm King, N. Y } \\
\text { Espoo, Finland }\end{array}$ & 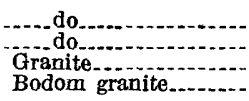 & $\begin{array}{r}64 \\
167 \\
337\end{array}$ & $\begin{array}{l}<1.0 \\
\sum 1.5 \\
<5\end{array}$ & $\begin{array}{l}<1.6 \\
<1.0 \\
<1.5\end{array}$ & $\begin{array}{l}\text { Do. } \\
\text { Do. } \\
\text { Do. } \\
\text { O. Kuovo (written }\end{array}$ \\
\hline $\begin{array}{l}\text { Lemi, Finland..... } \\
\text { Natzwiller, Vosges. }\end{array}$ & $\begin{array}{l}\text { Rapakivi granite... } \\
\text { Granite.............. }\end{array}$ & 73 & $\stackrel{(1)}{23}$ & 32 & $\begin{array}{l}\text { Do. } \\
\text { Faul, in Davis and }\end{array}$ \\
\hline $\begin{array}{l}\text { Col de la Grosse Pierre, } \\
\text { Vosges. } \\
\text { Wembach, Schwarzwald. }\end{array}$ & ..... do... & $\begin{array}{r}166 \\
46\end{array}$ & $\begin{array}{l}33 \\
5.1\end{array}$ & 20 & $\begin{array}{l}\text { Do. } \\
\text { Do. }\end{array}$ \\
\hline $\begin{array}{l}\text { Martinskapelle, Schwarz- } \\
\text { wald. }\end{array}$ & do & 163 & 96 & 59 & Do. \\
\hline $\begin{array}{l}\text { Martimskapelle, Schwarz- } \\
\text { wald, leached with hot } \\
\text { hydrochlorie acid. }\end{array}$ & $\ldots$............. & 86 & 29 & 34 & Do. \\
\hline $\begin{array}{l}\text { Halbmeil, Schwarzwald } \\
\text { Oslo, Norway }\end{array}$ & do & 78 & 31 & 40 & Do. \\
\hline Oslo, Norway & Nordmarkite...- & 17 & $<1$ & $<5$ & Do. \\
\hline
\end{tabular}

1 Not detactable.

The amount of original lead in the European zircon concentrates analyzed by Faul are in sharp contrast to those discussed above. Except for the one sample which contains less than 5 percent original lead, 5 samples contained amounts of original lead ranging from 11 to 40 percent. It is of interest to note that hot hydrochloric acid treatment of the zircon concentrate from Martinskapelle re- 
duced the total lead content from $163 \mathrm{ppm}$ of lead to $86 \mathrm{ppm}$ of lead. The amount of original lead was reduced from 59 percent to 34 percent. Thus a larger fraction of original lead is leached from the concentrate as compared to radiogenic lead. This would suggest that much of the soluble original lead is not present in the zircon lattice, but rather is present surficially.

Isotopic analyses of 13 monazite leads show that only 1 to 7 percent of the total lead is original (table 15). The lead found in most monazites is almost entirely radiogenic $\mathrm{Pb}^{208}$ produced from the decay of $\mathrm{Th}^{232}$. For example, monazite from Mountain Pass, Calif. (Jaffe, 1955) contained 98.85 percent of radiogenic lead consisting of 98.34 percent $\mathrm{Pb}^{208}$ and only 0.51 percent of $\mathrm{Pb}^{206}$, the latter produced from the decay of $U^{238}$. Only 1.15 percent of the total lead was found to be original lead based upon correction of the isotopic analysis of the monazite lead by that of Mountain Pass galena lead. The isotopic abundances of the monazite lead in atom percent were as follows:

\begin{tabular}{|c|c|c|c|c|c|}
\hline & 204 & 206 & 207 & 208 & Sum \\
\hline Total $\mathrm{Pb}$ & 0. 017 & 0. 782 & 0. 258 & 98. 943 & 100.000 \\
\hline Original $\mathrm{Pb}$ & .017 & .270 & .258 & .601 & 1. 146 \\
\hline Radiogenic $\mathrm{Pb}$ & $\ldots$ & .512 & - & 98. 342 & 98. 854 \\
\hline
\end{tabular}

NATURE OF LEAD IN ATLANITE, APATITE, AND_SPHENE

Lead-alpha ages were determined on several samples of allanite, sphene, and apatite and compared with the age determined on zircon from the same rocks. The ages determined on these minerals do not show the consistency obtained for zircon. Allanite, apatite, and sphene gave ages that were consistently older than those obtained on zircon from the same rock. The old ages determined suggest that allanite, sphene, and apatite either contain large amounts of original lead or they have all undergone a loss of uranium and thorium. In all probability the old ages of allanite result from a high content of original lead because of the following reasons:

1. $\mathrm{Pb}^{+2}$ (ionic radius $=1.32 \mathrm{~A}$ ) often replaces $\mathrm{Ca}^{+2}$ (ionic radius= $1.06 \mathrm{~A}$ ) in magmatic calcium minerals such as augite.

2. Allanite from Mountain Pass, Calif. (sample SQ-13, table 16) was associated with galena in the same rock, and field and petrographic observations indicate that they are cogenetic. The allanite was well crystallized with a high birefringence, strong pleochroism, and $n=1.818$, which indicates it to be a very fresh variety of this mineral. The close association with galena indicates that a large amount of lead was available at the time of crystallization. The very fresh nature of the allanite suggests the mineral has not lost uranium or thorium by alteration. 
TABLE 15.-Original lead content of isotopically analyzed monazite

\begin{tabular}{|c|c|c|c|}
\hline \multirow{2}{*}{ Locality and reference } & \multirow{2}{*}{$\begin{array}{c}\text { Total lead } \\
(\mathrm{ppm})\end{array}$} & \multicolumn{2}{|c|}{ Original lead } \\
\hline & & $\begin{array}{c}\text { Parts per } \\
\text { million }\end{array}$ & Percent \\
\hline $\begin{array}{l}\text { Mountain Isa mine, Queensland, Australia. } \\
\text { Holmes, 1948a. }\end{array}$ & 2,850 & 75 & 2. 6 \\
\hline $\begin{array}{l}\text { Las Vegas, near Santa Fe, N. Mex } \\
\text { Holmes, 1948a. }\end{array}$ & 3,720 & 63 & 1. 7 \\
\hline $\begin{array}{l}\text { Huron Claims, Manitoba, Canada } \\
\text { Holmes, } 1948 \mathrm{~b} \text {. }\end{array}$ & 15,240 & 150 & 1. 0 \\
\hline $\begin{array}{l}\text { Front Range, Colo } \\
\text { George Phair (oral communication). }\end{array}$ & 1,485 & 19 & 1. 3 \\
\hline $\begin{array}{l}\text { Mountain Pass, Calif } \\
\text { Jaffe, 1955. }\end{array}$ & 11,130 & 13 & 1. 1 \\
\hline $\begin{array}{l}\text { Goodhouse, Cape Province, South Africa... } \\
\text { Tilton and Nicolaysen, } 1957 \text {. }\end{array}$ & 3,770 & 38 & 1. 0 \\
\hline Bushveld complex, South Africa & 5,800 & 68 & 1. 2 \\
\hline Tilton and Nicolaysen, 1957. & 2,635 & 22 & 0.9 \\
\hline $\begin{array}{l}\text { Tilton and Nicolaysen, } 1957 \text {. } \\
\text { Van Rhynsdorp district, Cape Province, } \\
\text { South Africa }\end{array}$ & 3,040 & 202 & 6. 6 \\
\hline $\begin{array}{l}\text { Tilton and Nicolaysen, } 1957 \text {. } \\
\text { Yamba Lake, Northwest Territory, Canada -- } \\
\text { L. R. Stieff and T. W. Stern (oral communi- } \\
\text { cation). }\end{array}$ & 6,810 & None & \\
\hline Bikita district, South Rhodesia......... & 3,450 & None & \\
\hline $\begin{array}{l}\text { Holmes, 1954. } \\
\text { Salisbury, South Rhodesia........ }\end{array}$ & 9500 & 200 & 2.1 \\
\hline $\begin{array}{l}\text { Holmes, } 1954 . \\
\text { Holla }\end{array}$ & & & 2.1 \\
\hline $\begin{array}{l}\text { Irumi Hills, South Rhodesia.... } \\
\text { Holmes, } 1954 \text {. }\end{array}$ & 5,800 & 250 & 4. 3 \\
\hline
\end{tabular}

1 A new value of $1,740 \mathrm{ppm}$ was determined by isotope dilution by G. R. Tilton and L. R. Stieff (oral communication).

3. The allanites highest in activity (Conway granite and granite of Rubidoux Mountain, table 16) give ages closest to the probable geologic age and the zircon age. This would be expected because with increasing age, more radiogenic lead is produced and the original lead content becomes less significant.

A high original lead content can also be expected in sphene which has a defective lattice, and is capable of being a host for a great variety of ions (Sahama, 1946). Magmatic apatite also has a great capacity for rare-earth ions and is a common host mineral for lead.

\section{ACID LEACHING OF ZIRCON}

Some of the zircon analyzed for lead-alpha age determination shows a surface coating or stain which generally can be removed by leaching in concentrated nitric acid or 1 to 1 aqua regia. Other samples of zircon concentrates contain an abundance of pyrite or molybdenite which concentrates with zircon. Prior to the development of an effective small laboratory flotation cell, the sulfides had been removed 
TABLE 16.-Comparison of lead-alpha ages of allanite, apatite, and sphene with zircon

\begin{tabular}{|c|c|c|c|c|c|c|}
\hline $\begin{array}{l}\text { Rock type } \\
\text { Field No. } \\
\text { Locality } \\
\text { Collector }\end{array}$ & Mineral & c & $\begin{array}{l}a \text { per } \\
\text { mg } \\
\text { per } h r\end{array}$ & $\begin{array}{l}\text { Lead } \\
\text { (ppm) }\end{array}$ & $\begin{array}{l}\text { Lead- } \\
\text { alpha } \\
\text { age (mil- } \\
\text { lions of } \\
\text { years) }\end{array}$ & Probable geologic age \\
\hline $\begin{array}{l}\text { Woodson Mountain granodio- } \\
\text { rite. } \\
\text { S-2. } \\
\text { Southern California batho- } \\
\text { lith. } \\
\text { E. S. Larsen, Jr. }\end{array}$ & $\begin{array}{l}\text { Allanite } \\
\text { Zircon ---- }\end{array}$ & $\begin{array}{l}2,085 \\
2,485\end{array}$ & $\begin{array}{l}582 \\
433\end{array}$ & $\begin{array}{r}197 \\
21\end{array}$ & $\begin{array}{l}700 \\
121\end{array}$ & $\begin{array}{l}\text { Early Late Cretaceous } \\
\text { (Larsen, 1948). }\end{array}$ \\
\hline $\begin{array}{l}\text { Granite of Rubidoux Moun- } \\
\text { tain. } \\
\text { Z-15. } \\
\text { Southern California batho- } \\
\text { lith. } \\
\text { E. S. Larsen, Jr. }\end{array}$ & $\begin{array}{l}\text { Allanite.-- } \\
\text { Zircon..- }\end{array}$ & $\begin{array}{l}2,085 \\
2,485\end{array}$ & $\begin{array}{l}1,143 \\
2,700\end{array}$ & $\begin{array}{r}87 \\
106\end{array}$ & $\begin{array}{r}160 \\
98\end{array}$ & Do. \\
\hline $\begin{array}{l}\text { Quartz monzonite } \\
\text { G-21. } \\
\text { Southern California batho- } \\
\text { lith. } \\
\text { E. S. Larsen, Jr. }\end{array}$ & $\begin{array}{l}\text { Allanite--- } \\
\text { Zircon - - }\end{array}$ & $\begin{array}{l}2,085 \\
2,485\end{array}$ & $\begin{array}{l}698 \\
610\end{array}$ & $\begin{array}{r}210 \\
23\end{array}$ & $\begin{array}{r}620 \\
94\end{array}$ & $\begin{array}{l}\text { Mesozoic (Miller, } \\
\text { 1946). }\end{array}$ \\
\hline $\begin{array}{l}\text { Quartz monzonite } \\
\text { PB-4. } \\
\text { Sierra Nevada batholith, } \\
\text { near Bishop, Calif. } \\
\text { P. C. Bateman. }\end{array}$ & $\begin{array}{l}\text { Allanite } \\
\text { Zircon }\end{array}$ & $\begin{array}{l}2,085 \\
2,485\end{array}$ & $\begin{array}{l}523 \\
792\end{array}$ & $\begin{array}{r}180 \\
35\end{array}$ & $\begin{array}{l}720 \\
110\end{array}$ & $\begin{array}{l}\text { Late Jurassic (Hinds, } \\
\text { 1934). }\end{array}$ \\
\hline $\begin{array}{l}\text { Conway granite } \\
\text { White Mountain plutonic- } \\
\text { volcanic series, New } \\
\text { Hampshire. } \\
\text { A. Butler. }\end{array}$ & $\begin{array}{l}\text { Allanite... } \\
\text { Zircon } \\
- \text { do }\end{array}$ & $\begin{array}{l}2,085 \\
2,485 \\
2,485\end{array}$ & $\begin{array}{r}1,602 \\
298 \\
855\end{array}$ & $\begin{array}{l}203 \\
22.5 \\
63.5\end{array}$ & $\begin{array}{l}260 \\
188 \\
185\end{array}$ & $\begin{array}{l}\text { Mississippian(?) } \\
\text { (Billings, 1956). } \\
\text { Late Permian(?) } \\
\text { (Iyons and others, } \\
\text { 1957). }\end{array}$ \\
\hline $\begin{array}{l}\text { Barite-carbonate rock } \\
\text { SQ-13. } \\
\text { Associated with alkalic } \\
\text { syenite and shonkmite, } \\
\text { Mountain Pass, Calif. } \\
\text { H. W. Jaffe. }\end{array}$ & $\begin{array}{l}\text { Allanite..- } \\
\text { A patite... } \\
\text { Zircon }\end{array}$ & $\begin{array}{l}2,085 \\
2,485 \\
2,485 \\
2,485\end{array}$ & $\begin{array}{r}61 \\
120 \\
130 \\
270\end{array}$ & $\begin{array}{l}470 \\
150 \\
115 \\
110\end{array}$ & $\begin{array}{r}16,000 \\
3,100 \\
2,200 \\
932\end{array}$ & $\begin{array}{l}\text { Pre-Tertiary (Olson } \\
\text { and others, 1954). }\end{array}$ \\
\hline $\begin{array}{l}\text { Shonkinite. } \\
\text { NM-1. } \\
\text { Mountain Pass, Calif. } \\
\text { T. B. Nolan and W. T. } \\
\text { Pecora. }\end{array}$ & -_do_..... & 2,485 & 270 & 110 & 932 & Do. \\
\hline $\begin{array}{l}\text { Granodiorite. } \\
\text { HCD-62. } \\
\text { Gem stocks, Coeur d'Alene } \\
\text { district, Idaho. } \\
\text { A. B. Griggs. }\end{array}$ & $\begin{array}{l}\text { Zircon } \\
\text { and } \\
\text { thorite. } \\
\text { Sphene... }\end{array}$ & $\begin{array}{l}2,013 \\
2,485\end{array}$ & 1,739 & 25 & 460 & $\begin{array}{l}\text { Cretaceous or early } \\
\text { Tertiary (A. B. } \\
\text { Griggs, written com- } \\
\text { munication, 1956). }\end{array}$ \\
\hline $\begin{array}{l}\text { Granodiorite. } \\
\text { HCD-63. } \\
\text { Gem stocks, Coeur d'Alene } \\
\text { district, Idaho. } \\
\text { A. B. Griggs. }\end{array}$ & Zircon & $\begin{array}{l}2,485 \\
2,485\end{array}$ & $\begin{array}{r}80 \\
292\end{array}$ & $\begin{array}{l}15 \\
11\end{array}$ & $\begin{array}{r}430 \\
94\end{array}$ & Do. \\
\hline
\end{tabular}

by acid leaching. Apatite, normally removed in methylene iodide, may also concentrate with zircon either by being trapped by zircon in the liquid separation or by virtue of containing heavy ions such as $\mathrm{Sr}^{+2}$ and $\mathrm{Ce}^{+3}$ in substitution for $\mathrm{Ca}^{+2}$ in the lattice. In practice, apatite that does not float in methylene iodide is removed by acid leaching. Acid-leaching experiments were carried out on several samples of $-80+200$ mesh size crystals of both fresh and metamict zircon of different ages from several localities (table 17). Only small to 
TABLE 17.-Lead-alpha ages of zircon before and after leaching with acids

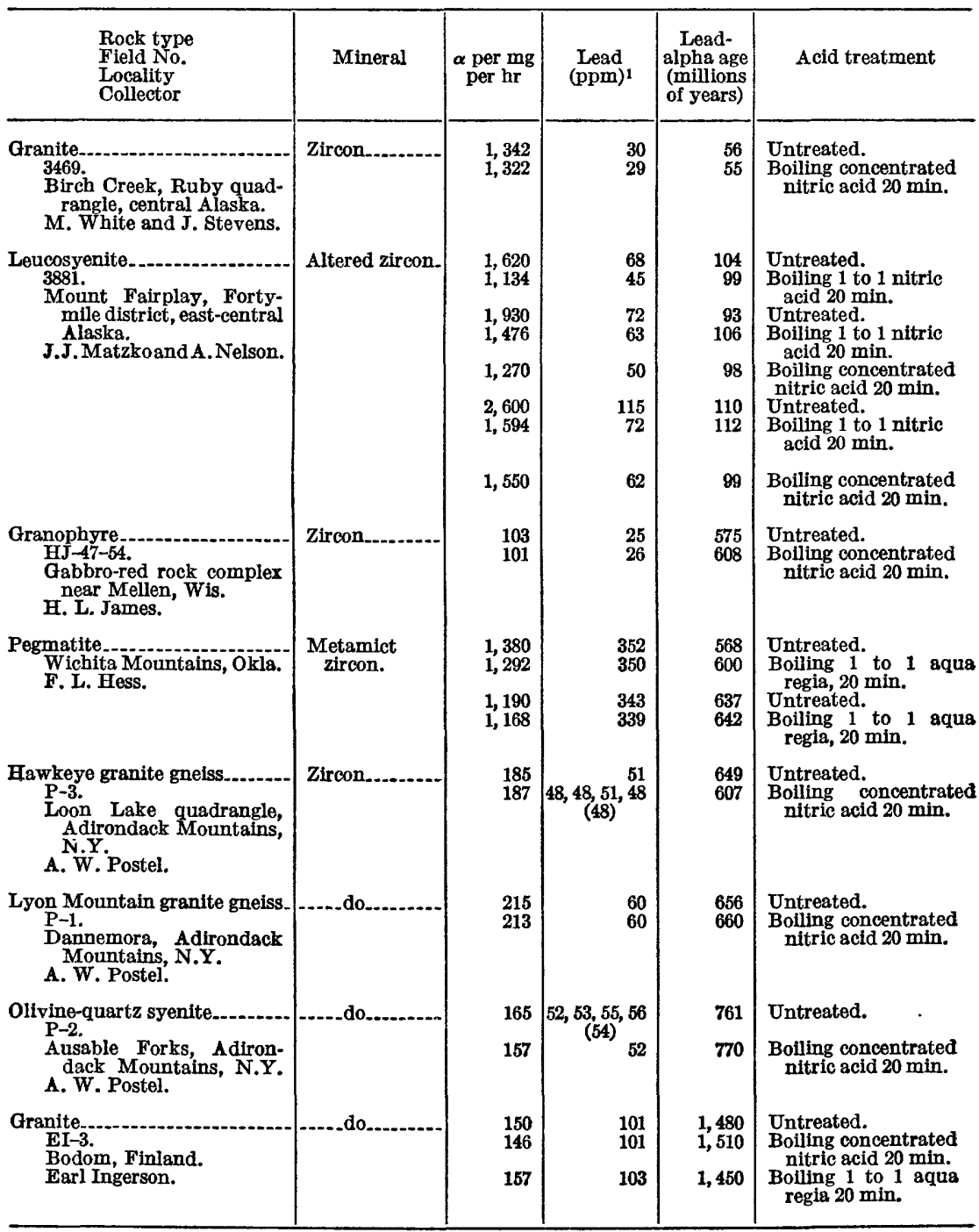

1 The figures in parentheses are the averages used in deriving the calculated ages.

negligible changes could be detected in either the alpha activity or lead content of the zircon before and after acid leaching. A change was not considered significant unless it exceeded the analytical reproducibility of \pm 5 percent for the alpha activity or \pm 10 percent for the lead determinations.

A detailed leaching study was made of zircon from the granite from Mount Fairplay, Alaska (John Matzko, H. W. Jaffe, and C.L. Waring, written communication). Zircon from this rock was separated into three fractions having distinctly different magnetic susceptibilities. 
Leaching of each fraction with nitric acid produced a 30 to 40 percent loss in alpha activity. The lead, however, showed a proportional decrease with the loss of alpha activity and the lead-alpha ages were basically unchanged after acid treatment, as shown in table 17. This indicated that neither uranium, thorium, nor lead had been selectively leached, but rather there had been solution of either metamict zones of zircon or thorite from the crystals. Inasmuch as the crystals were heavily stained before acid treatment, the identity of the soluble material was not established.

One sample of metamict zircon from the Wichita Mountains, Okla., showed a 7 percent loss in alpha activity after leaching for 20 minutes in 1 to 1 aqua regia. The lead remained virtually unchanged and the acid-leached sample therefore yielded an age about 7 percent older than the untreated zircon. Another specimen of metamict zircon from the same locality showed no significant change after acid leaching.

Metamict zircon from granite from Tory Hill showed a 10 percent loss in alpha activity after acid treatment. A lead value lower by 3 percent is within the limit of analytical error and may not be considered significant. The acid-leached zircon therefore showed an age about 7 percent higher than the unleached sample.

Other samples of both fresh and metamict zircon, ranging from 48 to $343 \mathrm{ppm}$ lead and in activity from 101 to 1,190 alpha per milligram per hour showed no loss of either alpha activity or lead content after acid treatment for 15 minutes in boiling concentrated nitric acid or aqua regia.

The results, therefore, indicate that acid leaching of zircon may produce a 5 to 10 percent loss in alpha activity in some samples of metamict zircon and no measurable loss in fresh zircon. Selective loss of lead could not be demonstrated in any of the samples. Acid treatment of fresh zircon will therefore not affect the lead-alpha age; acid treatment of metamict zircon may cause an increase in the age by 5 to 10 percent in some instances and no change in others.

It should be borne in mind that all varieties of metamict zircon do not fall into one category. Kostyleva (1946), has recognized two types of metamict zircon as follows:

1. The metamict state without the entry of water and with almost the theoretical composition of zircon.

2. The metamict state with the entry of water and with deviations from the composition of zircon. This group would include such varieties as cyrtolite.

All of the metamict zircon on which acid-leaching studies were made (table 17) fall into Kostyleva's first category. Cyrtolite and other metamict varieties of Kostyleva's second type might be subject to a much larger alpha activity loss and lead loss from acid leaching. 
Very little data on acid-wash experiments on zircon are reported in the literature. Tilton (1956) reported a lead loss of 15 percent on a zircon from a granite from Tory Hill, Ontario, after boiling the powdered mineral for 15 minutes in 1 to 1 aqua regia.

\section{INTERNAL CONSISTENCY OF THE METHOD}

\section{LEAD-AIPHA AGES OF MONAZITE, XENOTIME, AND THORITE .}

Although most of the lead-alpha ages have been determined on zircon, on many occasions it has been possible to obtain ages on two or three different minerals from the same rocks. Inasmuch as the isotopic data indicate that the amount of original lead in monazite is negligible this mineral should be suitable for the lead-alpha method. No data are available on the isotopic composition of lead in renotime.

Several igneous rocks ranging in composition from diorite to granite contained from about 1 to $10 \mathrm{ppm}$ thorite. This thorite is generally isotropic or has low birefringence with an average index of refraction of about 1.76. Because it is heavy (density $>3.2$ ) and nonmagnetic it is concentrated with the zircon in the final separation product. Thorite is readily soluble in acid and can be removed easily from the zircon separate. Natural mixtures of these two minerals have shown ages that are in close agreement with the ages obtained on zircon after leaching the thorite. A few isotopic analyses of thorite indicato the common lead content is small (Nier, 1939).

A comparison of ages obtained on two or more of these minerals separated from the same rock, ranging from Tertiary to Precambrian in age, is given in table 18. The close agreement of ages on these different suites of cogenetic minerals containing widely different amounts of lead and alpha activity and different proportions of uranium and thorium demonstrates the internal consistency of the method.

\section{ZIRCON OF DIFFERENT IEAD CONTENT AND ALPHA ACTIVITY}

Zircon concentrates separated from the same rock often contain fresh and metamict varieties of zircon that contain widely different amounts of lead and radioactivity. Although zircon is ordinarily nonmagnetic on the Frantz separator, some varieties of zircon can be concentrated in different magnetic fractions. When both varieties are present in a concentrate or a single crystal, two or more age measurements can be made on samples that contain different amounts of lead and alpha activity. This technique was used by Larsen, Waring, and Berman (1953) on zircon in pegmatite from Oklahoma that contained both fresh and metamict zones in the same crystal. Lead-alpha activity ratios on the fresh and metamict zircon that contained about 40 and $350 \mathrm{ppm}$ lead, respectively, showed ages that agreed to within \pm 10 percent. Lead-alpha age measurements also agreed to within \pm 10 
TABLE 18.-Comparison of lead-alpha ages of monazite, wenotime, thorite, and zircon

\begin{tabular}{|c|c|c|c|c|c|}
\hline $\begin{array}{l}\text { Rock type } \\
\text { Field No. } \\
\text { Locality } \\
\text { Collector }\end{array}$ & Mineral & $\begin{array}{l}\alpha \text {, per } \\
\text { mg. per } \\
\text { hr. }\end{array}$ & $\underset{(\mathrm{ppm})^{1}}{\text { Lead }}$ & $\begin{array}{l}\text { Lead- } \\
\text { alpha age } \\
\text { (millions } \\
\text { of years) }\end{array}$ & Probable geologic age \\
\hline Granite......... & Monazite... & 7,657 & 55,58 & 15 & Unknown (T. S. \\
\hline $\begin{array}{l}\text { Lov-1. } \\
\text { Tooele County, Utah. } \\
\text { T. S. Lovering. }\end{array}$ & Zircon & 1,920 & $\begin{array}{c}(56.5) \\
15,15,16,16 \\
(15.5)\end{array}$ & 20 & $\begin{array}{l}\text { Lovering, written } \\
\text { communication, } \\
\text { 1954). }\end{array}$ \\
\hline $\begin{array}{l}\text { Diorite } \\
\text { Z-24. } \\
\text { Clayton Peak stock, near } \\
\text { Brighton, Utah. } \\
\text { M. Crittenden. }\end{array}$ & $\begin{array}{l}\text { Thorite...... } \\
\text { Zircon...... }\end{array}$ & $\begin{array}{l}5,795 \\
3,330\end{array}$ & $\begin{array}{r}115 \\
65\end{array}$ & $\begin{array}{l}40 \\
48\end{array}$ & $\begin{array}{l}\text { Unknown (M. } \\
\text { Crittenden, written } \\
\text { communication, } \\
\text { 1956). }\end{array}$ \\
\hline $\begin{array}{l}\text { Gneissic granite } \\
\text { 53C-210. } \\
\text { Lost Horse Creek, near } \\
\text { Idaho-Montana State line. } \\
\text { R. W. Chapinan. }\end{array}$ & $\begin{array}{l}\text { Monazite...- } \\
\text { Zircon }\end{array}$ & $\begin{array}{r}3,213 \\
275\end{array}$ & $\begin{array}{r}79 \\
6.2\end{array}$ & $\begin{array}{l}51 \\
56\end{array}$ & $\begin{array}{l}\text { Cretaceous (Ross, } \\
\text { 1952). }\end{array}$ \\
\hline $\begin{array}{l}\text { Porphyritic granodiorite....... } \\
\text { CP R-122. } \\
\text { Lost Horse Creek, near } \\
\text { Idaho-Montana State line. } \\
\text { B. F. Leonard and C. P. } \\
\text { Ross. }\end{array}$ & $\begin{array}{l}\text { Monazite... } \\
\text { Zircon..... }\end{array}$ & $\begin{array}{r}3,385 \\
257\end{array}$ & $\begin{array}{l}90,90 \\
(90) \\
6.0,7.0 \\
(6.5)\end{array}$ & $\begin{array}{l}55 \\
63\end{array}$ & Do. \\
\hline $\begin{array}{l}\text { Gneissic granodiorite. } \\
\text { CPR-123. } \\
\text { Lost Horse Creek, near } \\
\text { Idaho-Montana State line. } \\
\text { B. F. Leonard and C. } R \text {. } \\
\text { Ross. }\end{array}$ & $\begin{array}{l}\text { Monazite..... } \\
\text { Zireon....... }\end{array}$ & $\begin{array}{r}2,925 \\
262\end{array}$ & $\begin{array}{l}80,80 \\
(80) \\
5.0,6.0 \\
(5.5)\end{array}$ & $\begin{array}{l}57 \\
53\end{array}$ & $\begin{array}{l}\text { Cretaceous (Ross, } \\
\text { 1952). }\end{array}$ \\
\hline $\begin{array}{l}\text { Alaskite } \\
\text { 52C-8. } \\
\text { Boulder batholith, Montana. } \\
\text { R. W. Chapman. }\end{array}$ & $\begin{array}{l}\text { Monazite } \\
\text { Zircon }\end{array}$ & $\begin{array}{l}6,733 \\
4,990\end{array}$ & $\begin{array}{l}231 \\
127\end{array}$ & $\begin{array}{l}72 \\
63\end{array}$ & $\begin{array}{l}\text { Late Cretaceous or } \\
\text { early Tertiary } \\
\text { (Knopf, 1957). }\end{array}$ \\
\hline $\begin{array}{l}\text { Granodiorite } \\
\text { PB-3. } \\
\text { Sierra Nevada batholith, } \\
\text { near Bishop, Calif. } \\
\text { P. C. Bateman. }\end{array}$ & $\begin{array}{l}\text { Thorite } \\
\text { Zircon.......... }\end{array}$ & $\begin{array}{r}4,670 \\
400\end{array}$ & $\begin{array}{r}205 \\
15\end{array}$ & $\begin{array}{l}88 \\
93\end{array}$ & $\begin{array}{l}\text { Late Jurassic (Hinds, } \\
\text { 1934). }\end{array}$ \\
\hline $\begin{array}{l}\text { Half Dome quartz monzonite.... } \\
53 \text { PB-10. } \\
\text { Yosemite National } \\
\text { Park, Calif. } \\
\text { P. C. Bateman. }\end{array}$ & $\begin{array}{l}\text { Thorite } \\
\text { Zircon.....-. }\end{array}$ & $\begin{array}{r}10,370 \\
330\end{array}$ & $\begin{array}{r}454 \\
15,16 \\
(15.5)^{-}\end{array}$ & $\begin{array}{r}88 \\
117\end{array}$ & Do. \\
\hline $\begin{array}{l}\text { Quartz diorite. } \\
\text { L-113. batholith, near } \\
\text { Idaho batley, Idaho. } \\
\text { Stanley } \\
\text { E. S. Larsen, Jr. }\end{array}$ & $\begin{array}{l}\text { Thorite...... } \\
\text { Zircon....... }\end{array}$ & $\begin{array}{r}1,375 \\
825\end{array}$ & $\begin{array}{l}70 \\
30\end{array}$ & $\begin{array}{r}102 \\
90\end{array}$ & $\begin{array}{l}\text { Cretaceous (Ross and } \\
\text { Forrester, 1947). }\end{array}$ \\
\hline $\begin{array}{l}\text { Porphyritic granodiorite......... } \\
\text { L53-573a. } \\
\text { Big Creek quadrangle, Idaho } \\
\text { batholith, Idaho. } \\
\text { B. F. Leonard. }\end{array}$ & $\begin{array}{l}\text { Monazite } . .- \\
\text { Zircon }\end{array}$ & $\begin{array}{r}2,726 \\
340\end{array}$ & $\begin{array}{l}144,148 \\
(146) \\
13,15 \\
(14)\end{array}$ & $\begin{array}{l}112 \\
102\end{array}$ & Do. \\
\hline $\begin{array}{l}\text { Granite } \\
\text { G-199. } \\
\text { Idaho batholith, } 15 \text { miles } \\
\text { northeast of Garden Val- } \\
\text { ley, Idaho. } \\
\text { David Gottiried. }\end{array}$ & $\begin{array}{l}\text { Monazite ... } \\
\text { Xenotime... } \\
\text { Zircon.....- }\end{array}$ & $\begin{array}{l}5,617 \\
6,025 \\
1,970\end{array}$ & $\begin{array}{l}250,256 \\
(253) \\
220 \\
90\end{array}$ & $\begin{array}{r}93 \\
93 \\
114\end{array}$ & Do. \\
\hline $\begin{array}{l}\text { Woodson Mountain granodiorite. } \\
\text { Z-16. } \\
\text { Lescanso Junction, southern } \\
\text { California batholith. } \\
\text { E. S. Larsen, Jr. }\end{array}$ & $\begin{array}{l}\text { Xenotime... } \\
\text { Zircon }\end{array}$ & $\begin{array}{l}6,400 \\
1,235\end{array}$ & $\begin{array}{r}260 \\
50\end{array}$ & $\begin{array}{l}104 \\
101\end{array}$ & $\begin{array}{l}\text { Early Late Cretaceous } \\
\text { (Larsen; 1948). }\end{array}$ \\
\hline $\begin{array}{l}\text { Woodson Mountain granodiorite- } \\
\text { S-6. } \\
\text { Northeast of Descanso Junc- } \\
\text { tion, southern California } \\
\text { batholith. } \\
\text { E. S. Larsen, Jr. }\end{array}$ & $\begin{array}{l}\text { Monazite } \\
\text { Zircon... }\end{array}$ & $\begin{array}{l}6,430 \\
1,180\end{array}$ & $\begin{array}{r}360 \\
46\end{array}$ & $\begin{array}{r}117 \\
97\end{array}$ & $\begin{array}{l}\text { Early Late Cretaceous } \\
\text { (Larsen, 1948). }\end{array}$ \\
\hline
\end{tabular}


TABLE 18.-Comparison of lead-alpha ages of monazite, xenotime, thorite, and zircon-Continued

\begin{tabular}{|c|c|c|c|c|c|}
\hline $\begin{array}{l}\text { Rock type } \\
\text { Field No. } \\
\text { Locality } \\
\text { Collector }\end{array}$ & Mineral & $\begin{array}{l}\alpha, \text { per } \\
\text { mg.per } \\
\text { hr. }\end{array}$ & $\underset{(\mathrm{ppm})^{1}}{\text { Lead }}$ & $\begin{array}{l}\text { Lead- } \\
\text { alpha age } \\
\text { (millions } \\
\text { of years) }\end{array}$ & Probable geologic age \\
\hline $\begin{array}{l}\text { Bethlehem gneiss. } \\
\text { NH-S-4-52-1. } \\
\text { Sunapee quadrangle, New } \\
\text { Hampshire plutonic series, } \\
\text { New Hampshire. } \\
\text { J. B. Lyons. }\end{array}$ & $\begin{array}{l}\text { Monazite } \\
\text { Xenotime--: } \\
\text { Zircon }\end{array}$ & $\begin{array}{r}2,922 \\
4,053 \\
242\end{array}$ & $\begin{array}{r}470 \\
530 \\
30\end{array}$ & $\begin{array}{l}342 \\
266 \\
297\end{array}$ & $\begin{array}{l}\text { Late Devonian(?) } \\
\text { (Billings, 1956). }\end{array}$ \\
\hline $\begin{array}{l}\text { Pegmatite intrusive into Toluca } \\
\text { quartz monzonite. } \\
\text { 490t-16. } \\
\text { Cleveland County, N.C. } \\
\text { W. C. Overstreet. }\end{array}$ & $\begin{array}{l}\text { Monazite } \\
\text { Zircon }\end{array}$ & $\begin{array}{r}5,685 \\
456 \\
452\end{array}$ & $\begin{array}{r}1,050 \\
81 \\
82\end{array}$ & $\begin{array}{l}380 \\
427 \\
\mathbf{4 3 5}\end{array}$ & $\begin{array}{l}\text { Paleozoic (Griffitts } \\
\text { and Overstreet, } \\
\text { 1952). }\end{array}$ \\
\hline $\begin{array}{l}\text { Pegmatite intrusive into Toluca } \\
\text { quartz monzonite. } \\
\text { 530t-14. } \\
\text { Cleveland County, N.C. } \\
\text { W. C. Overstreet. }\end{array}$ & $\begin{array}{l}\text { Monazite_... } \\
\text { Zircon }\end{array}$ & $\begin{array}{r}5,464 \\
652\end{array}$ & $\begin{array}{r}1,000 \\
124\end{array}$ & $\begin{array}{l}377 \\
456\end{array}$ & $\begin{array}{l}\text { Paleozoic (Griffitts and } \\
\text { Overstreet, 1952). }\end{array}$ \\
\hline $\begin{array}{l}\text { Granodiorite gneiss............ } \\
54 J-1 \text {. } \\
\text { U.S. Highway 211, 1.6 miles } \\
\text { west of Sperryville, Va. } \\
\text { H. W. Jaffe. }\end{array}$ & $\begin{array}{l}\text { Monazite_..- } \\
\text { Zircon }\end{array}$ & $\begin{array}{r}8,786 \\
686 \\
854\end{array}$ & $\begin{array}{r}2,000 \\
135 \\
160\end{array}$ & $\begin{array}{l}468 \\
470 \\
449\end{array}$ & $\begin{array}{l}\text { Precambrian (J. C. } \\
\text { Reed, Jr., written } \\
\text { communieation, } \\
\text { 1955). }\end{array}$ \\
\hline $\begin{array}{l}\text { Pegmatite. } \\
62081 . \\
\text { Tambane, Nyasaland, Af- } \\
\text { rica. Tilley. }\end{array}$ & $\begin{array}{l}\text { Monazite...- } \\
\text { Zircon-...-. }\end{array}$ & $\begin{array}{r}1,634 \\
185 \\
375\end{array}$ & $\begin{array}{r}430 \\
47 \\
85\end{array}$ & $\begin{array}{l}539 \\
600 \\
638\end{array}$ & $\begin{array}{l}\text { Late Precambrian (C. } \\
\text { E. Tilley, written } \\
\text { communication, } \\
\text { 1953). }\end{array}$ \\
\hline $\begin{array}{l}\text { Pegmatite } \\
\text { Co-R-Goo. } \\
\text { Greenville, Routt County, } \\
\text { Colo. } \\
\text { R. S. Cannon. }\end{array}$ & $\begin{array}{l}\text { Monazite...- } \\
\text { Xenotime_.. }\end{array}$ & $\begin{array}{l}1,749 \\
2,390\end{array}$ & $\begin{array}{c}1,250,1,270 \\
(1,260) \\
1,550,1,560 \\
(1,555)\end{array}$ & $\begin{array}{l}1,430 \\
1,420\end{array}$ & $\begin{array}{l}\text { Precambrian (R. } \\
\text { Cannon, written } \\
\text { communuication, } \\
\text { 1957). }\end{array}$ \\
\hline
\end{tabular}

The figures in parentheses are the averages used in deriving the calculated ages.

percent on a suite of 21 gem-quality crystals of zircon from Ceylon which ranged from 22 to $500 \mathrm{ppm}$ of lead (Gottfried, Senftle, and Waring, 1956). Some of the data of these investigations and other similar examples are given in table 19.

In addition to obtaining different varieties of zircon on the basis of magnetic susceptibility, sieving the concentrate into different size fractions has been used as another means for obtaining samples of zircon that are different in alpha activity and lead content. Zircon crystals range in size from 80 mesh to less than 400 mesh and usually are liberated from the rock during crushing as entire crystals. In general the smaller zircon crystals contain either the same or greater amounts of radioactivity than the larger zircon crystals from the same rock. Effects of alteration by solutions, metamorphism, or diffusion of lead would be much greater in minute zircon crystals that have a high lead content and that have undergone extensive radiation damage. Close agreement in age between different size fractions has nearly always been obtained on zircon from rocks ranging in age from Tertiary to Precambrian. The data are given in table 20. 


\section{TABLE 19.-Comparison of lead-alpha ages of zircon fractions of different radio- activity and lead content from the same rock}

\begin{tabular}{|c|c|c|c|c|c|}
\hline $\begin{array}{l}\text { Rock type } \\
\text { Field No. } \\
\text { Locality } \\
\text { Collector }\end{array}$ & Mineral & $\begin{array}{c}\alpha \text { per mg } \\
\text { per } \mathrm{hr}\end{array}$ & $\underset{(\mathrm{ppm})^{1}}{\text { Lesd }}$ & $\begin{array}{c}\text { Lead- } \\
\text { alpha age } \\
\text { (millions } \\
\text { of years) }\end{array}$ & Probable geologic age \\
\hline $\begin{array}{l}\text { Monzonite porphyry. } \\
\text { LS-7-55. } \\
\text { North La Sal Mountains, Utah. } \\
\text { D. R. Shawe. }\end{array}$ & Zircon..... & $\begin{array}{l}3,180 \\
3,720\end{array}$ & $\begin{array}{l}70,70 \\
(70) \\
75,79 \\
(77)\end{array}$ & $\begin{array}{l}55 \\
51\end{array}$ & $\begin{array}{l}\text { Tertiary (Waters, } \\
\text { 1955). }\end{array}$ \\
\hline $\begin{array}{l}\text { Leucosyenite. } \\
\text { 3881. } \\
\text { Mount Fairplay, Fortymile dis- } \\
\text { trict, east-central Alaska. } \\
\text { J. J. Matzko and A. Nelson. }\end{array}$ & -...do......... & $\begin{array}{l}1,134 \\
1,270 \\
1,550\end{array}$ & $\begin{array}{l}45 \\
50 \\
62\end{array}$ & $\begin{array}{l}99 \\
98 \\
99\end{array}$ & $\begin{array}{l}\text { Mesozoic(?) (Mertie, } \\
\text { 1937). }\end{array}$ \\
\hline $\begin{array}{l}\text { Monzodiorite, dike } \\
\text { White. Mountain plutonic-vol- } \\
\text { canic series, Lake Winnepesau- } \\
\text { kee quadrangle, New Hamp- } \\
\text { shire. } \\
\text { H. W. Jaffe and J. B. Lyons. }\end{array}$ & ....do.... & $\begin{array}{l}260 \\
650\end{array}$ & $\begin{array}{l}18,20 \\
(19) \\
46,48 \\
(47)\end{array}$ & $\begin{array}{l}182 \\
180\end{array}$ & $\begin{array}{l}\text { Mississippian(?) } \\
\text { (Billings, 1956). } \\
\text { Late Permian(?) } \\
\text { (Lyons and others, } \\
\text { 1957). }\end{array}$ \\
\hline $\begin{array}{l}\text { Scituate granite gneiss...... } \\
\text { Q-53-37. } \\
\text { North Scituate and Georgiaville } \\
\text { quadrangles, Rhode Island. } \\
\text { A. W. Quinn. }\end{array}$ & .....do... & $\begin{array}{l}251 \\
352\end{array}$ & $\begin{array}{l}35 \\
\mathbf{4 4}\end{array}$ & $\begin{array}{l}337 \\
303\end{array}$ & $\begin{array}{l}\text { Pre-Pennsylvanian, } \\
\text { (Devoniani or older). } \\
\text { (Quinn and others, } \\
\text { 1957). }\end{array}$ \\
\hline $\begin{array}{l}\text { Gem gravels, derived from pegma- } \\
\text { tite. } \\
\text { Ceylon. }\end{array}$ & .... do... & $\begin{array}{r}103 \\
273 \\
643 \\
882 \\
1,185 \\
1,245 \\
1,815 \\
2,210\end{array}$ & $\begin{array}{r}22 \\
65 \\
150 \\
205 \\
275 \\
270 \\
450 \\
498\end{array}$ & $\begin{array}{l}\mathbf{5 3 2} \\
\mathbf{5 9 0} \\
578 \\
576 \\
576 \\
538 \\
613 \\
\mathbf{6 6 0}\end{array}$ & $\begin{array}{l}\text { Precambrian (Wadia } \\
\text { and Fernando, 1944). }\end{array}$ \\
\hline $\begin{array}{l}\text { Syenite. } \\
\text { AND-3. } \\
\text { Wet Mountains, Custer County, } \\
\text { Colo. } \\
\text { Q. D. Singewald. }\end{array}$ & ....do_... & $\begin{array}{r}319 \\
452 \\
770 \\
1,060 \\
\mathbf{1}, 680 \\
\mathbf{3}, \mathbf{5 2 0}\end{array}$ & $\begin{array}{r}78 \\
115 \\
192 \\
290 \\
430 \\
980\end{array}$ & $\begin{array}{l}580 \\
601 \\
590 \\
644 \\
605 \\
655\end{array}$ & $\begin{array}{l}\text { Later than Precambrain } \\
\text { regional metamorph- } \\
\text { ism; upper age limit } \\
\text { is not known (Q. D. } \\
\text { Singewald, written } \\
\text { communication, } \\
\text { 1956). }\end{array}$ \\
\hline $\begin{array}{l}\text { Nepheline syenite } \\
62117 . \\
\text { Nyasaland, Africa. } \\
\text { C. E. Tilley. }\end{array}$ & ....do..... & $\begin{array}{l}344 \\
358 \\
380 \\
489\end{array}$ & $\begin{array}{r}75 \\
85 \\
86 \\
105\end{array}$ & $\begin{array}{l}519 \\
562 \\
537 \\
512\end{array}$ & $\begin{array}{l}\text { Late Precambrian } \\
\text { (C. E. Tilley, } \\
\text { written communica- } \\
\text { tion, 1954). }\end{array}$ \\
\hline $\begin{array}{l}\text { Granite. } \\
\text { EI-3. } \\
\text { Bodom, Finland. } \\
\text { Earl Ingerson. }\end{array}$ & $\ldots$ do & $\begin{array}{l}146 \\
184\end{array}$ & $\begin{array}{l}101 \\
120\end{array}$ & $\begin{array}{l}1,510 \\
1,440\end{array}$ & $\begin{array}{l}\text { Precambrian (A. } \\
\text { Kahma, written } \\
\text { commumication, 1955). }\end{array}$ \\
\hline $\begin{array}{l}\text { MeGrath gneiss. } \\
1203 \text {. } \\
\text { McGrath, Minn. } \\
\text { R. G. Schmidt. }\end{array}$ & .....do........ & $\begin{array}{l}318 \\
353\end{array}$ & $\begin{array}{l}228,232 \\
(230) \\
255,260 \\
(257)\end{array}$ & $\begin{array}{l}1,560 \\
1,570\end{array}$ & $\begin{array}{l}\text { Precambrian (Woyski, } \\
\text { 1949). }\end{array}$ \\
\hline $\begin{array}{l}\text { Pegmatite } \\
\text { Wichita Mountains, Okla. } \\
\text { F. L. Hess. }\end{array}$ & -...do-..... & $\begin{array}{l}168 \\
1,180 \\
1,190 \\
1,230 \\
1,380\end{array}$ & $\begin{array}{r}43 \\
340 \\
343 \\
360 \\
352\end{array}$ & $\begin{array}{l}579 \\
638 \\
637 \\
648 \\
567\end{array}$ & $\begin{array}{l}\text { Late Precambrian } \\
\text { ('Taylor, 1915). }\end{array}$ \\
\hline
\end{tabular}

1 The figures in parentheses are the averages used in deriving the calculated ages. 
TABLE 20.-Comparison of lead-alpha ages of zircon fractions of different crystal size from the same rock

\begin{tabular}{|c|c|c|c|c|c|c|}
\hline $\begin{array}{l}\text { Rock type } \\
\text { Field No. } \\
\text { Locality } \\
\text { Collector }\end{array}$ & Mineral & Mesh size & $\underset{\text { per } h \mathrm{hr}}{\alpha \text { per }}$ & $\underset{\text { (ppm)1 }}{\text { Lead }}$ & $\begin{array}{l}\text { Lead } \\
\text { alpha age } \\
\text { (millions } \\
\text { of years) }\end{array}$ & Probable geologic age \\
\hline $\begin{array}{l}\text { Quartz latite porphyry } \\
\text { plutonic. } \\
\text { GL-6. } \\
\text { San Juan Moun- } \\
\text { tains, Colo. } \\
\text { David Gottried } \\
\text { and George Phair. }\end{array}$ & Zircon..... & $\begin{array}{r}-80+200 \\
-200+400\end{array}$ & $\begin{array}{l}56 \\
58\end{array}$ & $\begin{array}{r}0.4 \\
0.4,0.6 \\
(0.5)\end{array}$ & $\begin{array}{l}17 \\
21\end{array}$ & $\begin{array}{l}\text { Miocene (Larsen and } \\
\text { Cross, 1956). }\end{array}$ \\
\hline $\begin{array}{l}\text { Granodiorite. } \\
\text { RLS-2. } \\
\text { Valles Mountains, } \\
\text { N.Mex. } \\
\text { R. L. Smith. }\end{array}$ & -...do......... & $\begin{array}{l}-80+400 \\
-400\end{array}$ & $\begin{array}{l}424 \\
547\end{array}$ & $\begin{array}{c}\text { 4. } 0,4.0 \\
(4.0) \\
\text { 3. } 0,4.0 \\
(3.5)\end{array}$ & $\begin{array}{l}23 \\
16\end{array}$ & $\begin{array}{l}\text { Tertiary (C. S. Ross } \\
\text { and R. L. Smith, } \\
\text { written communi- } \\
\text { cation, 1956). }\end{array}$ \\
\hline $\begin{array}{l}\text { Monzonite- } \\
\text { RLS-1. } \\
\text { Oerrillos Hills, N. } \\
\text { Mex. } \\
\text { R. L. Smith. }\end{array}$ & $\ldots$ do........ & $\begin{array}{l}-80+400 \\
-80+200 \\
-200+400 \\
-400\end{array}$ & $\begin{array}{l}760 \\
770 \\
780 \\
840\end{array}$ & $\begin{array}{r}13,14,15 \\
(14) \\
9,11 \\
(10) \\
10,12 \\
(11) \\
14,15,17 \\
(15.5)\end{array}$ & $\begin{array}{l}46 \\
32 \\
35 \\
46\end{array}$ & $\begin{array}{l}\text { Oligocene (post-Es- } \\
\text { pinaso volcanics, } \\
\text { pre-A biquiu(?) } \\
\text { formation) (Stearns, } \\
\text { 1953). }\end{array}$ \\
\hline $\begin{array}{l}\text { Quartz monzonite...... } \\
\text { HTM-1. } \\
\text { Silver City stock, } \\
\text { Tintic district, } \\
\text { Utah. } \\
\text { H. T. Morris. }\end{array}$ & .._do...... & $\begin{array}{l}-100+200 \\
-200+400\end{array}$ & $\begin{array}{l}187 \\
223\end{array}$ & $\begin{array}{l}3.7 \\
4.5\end{array}$ & $\begin{array}{l}49 \\
50\end{array}$ & $\begin{array}{l}\text { Middle Eocene } \\
\text { (Green River) } \\
\text { (H. T. Morris and } \\
\text { T.S. Loverimg, } \\
\text { written communi- } \\
\text { cation, 1956). }\end{array}$ \\
\hline $\begin{array}{l}\text { Porphyritic potassic } \\
\text { syenite. } \\
\text { P-50-49. } \\
\text { Bearpaw Moun- } \\
\text { tains, Mont. } \\
\text { W. T. Pecora. }\end{array}$ & .._do......... & $\begin{array}{r}-80+100 \\
-100+200\end{array}$ & $\begin{array}{l}290 \\
275\end{array}$ & $\begin{array}{l}5.2,5.6 \\
(5.4) \\
5.0,5.1 \\
(5.05)\end{array}$ & $\begin{array}{l}46 \\
46\end{array}$ & $\begin{array}{c}\text { Middle Eocene } \\
\text { (Green River) } \\
\text { (Brown and } \\
\text { Pecora, 1949). }\end{array}$ \\
\hline $\begin{array}{l}\text { Granodiorite. } \\
\text { JPO-1. } \\
\text { Batholith, Limo- } \\
\text { nes, Puerto Rico. } \\
\text { J. P. Owens. }\end{array}$ & ._-_do_..... & $\begin{array}{r}-80+200 \\
-200+400\end{array}$ & $\begin{array}{l}141 \\
212\end{array}$ & $\begin{array}{l}\text { 3. } 0,3.0 \\
(3.0) \\
4.0,5.0 \\
(4.5)\end{array}$ & $\begin{array}{l}53 \\
53\end{array}$ & Eocene (Kaye, 1957). \\
\hline $\begin{array}{l}\text { Isabella granodiorite. } \\
\text { EMM-1. } \\
\text { Kern River area, } \\
\text { California. } \\
\text { E. M. MacKevett. }\end{array}$ & ..._do_......... & $\begin{array}{l}-80+200 \\
-200+400 \\
-400\end{array}$ & $\begin{array}{l}283 \\
320 \\
351\end{array}$ & $\begin{array}{c}9,10 \\
(9.5) \\
11,12 \\
(11.5) \\
13,14 \\
(13.5)\end{array}$ & $\begin{array}{l}83 \\
89 \\
96\end{array}$ & $\begin{array}{c}\text { Late Jurassic(?) } \\
\text { (Hinds, 1934). }\end{array}$ \\
\hline $\begin{array}{l}\text { Syenite- } \\
\text { VT-sy-56 J-12. } \\
\text { White Mountain } \\
\text { plutonic-volcanic } \\
\text { series, Mount } \\
\text { Ascutney, Vt. } \\
\text { H. W. Jafre and } \\
\text { J. B. Lyons. }\end{array}$ & $\ldots$ do do......... & $\begin{array}{l}-80+200 \\
-200+400\end{array}$ & $\begin{array}{l}166 \\
214\end{array}$ & $\begin{array}{c}11,12 \\
(11.5) \\
20,17 \\
(18.5)\end{array}$ & $\begin{array}{l}172 \\
211\end{array}$ & $\begin{array}{l}\text { Mississippian(?) } \\
\text { (Billings, 1956). } \\
\text { Late Permian(?) } \\
\text { (Lyons and others, } \\
\text { 1957). }\end{array}$ \\
\hline $\begin{array}{l}\text { Mount Osceola granite.- } \\
\text { 99 BNH-67A. } \\
\text { White Mountain } \\
\text { plutonic-volcanic } \\
\text { series, Franconia } \\
\text { quadrangle, New } \\
\text { Hampshire. } \\
\text { A. Butler. }\end{array}$ & ...do..... & $\begin{array}{l}-80+200 \\
-200+400\end{array}$ & $\begin{array}{l}446 \\
508\end{array}$ & $\begin{array}{c}33,37 \\
(35) \\
38,39 \\
(38.5)\end{array}$ & $\begin{array}{l}195 \\
188\end{array}$ & $\begin{array}{l}\text { Mississippian(?) } \\
\text { (Billings, 1956). } \\
\text { Late Permian(?) } \\
\text { (Lyons and others, } \\
\text { 1957). }\end{array}$ \\
\hline $\begin{array}{l}\text { Cowesett granite.... } \\
\text { Q-48-3. } \\
\text { Cowesett, R.I. } \\
\text { A. W. Quinn. }\end{array}$ & ...do......... & $\begin{array}{l}-80+200 \\
-200+400 \\
-400\end{array}$ & $\begin{array}{l}134 \\
217 \\
322\end{array}$ & $\begin{array}{l}14,16 \\
(15) \\
24,25 \\
(24) \\
33,35 \\
(34)\end{array}$ & $\begin{array}{l}272 \\
272 \\
257\end{array}$ & $\begin{array}{l}\text { Mississippian(?) } \\
\text { (Quinn and others) } \\
\text { 1957. }\end{array}$ \\
\hline
\end{tabular}

See footnote at end of table. 
TABLE 20.-Comparison of lead-alpha ages of zircon fractions of different orystal size from the same rock-Continued

\begin{tabular}{|c|c|c|c|c|c|c|}
\hline $\begin{array}{l}\text { Rock type } \\
\text { Field No. } \\
\text { Locality } \\
\text { Collector }\end{array}$ & Mineral & Mesh size & 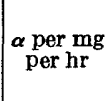 & $\underset{(\mathrm{ppm})^{1}}{\text { Lead }}$ & $\begin{array}{l}\text { Lead } \\
\text { alpha age } \\
\text { (millions } \\
\text { of years) }\end{array}$ & Probable geologic age \\
\hline $\begin{array}{l}\text { Winnepesaukee quartz } \\
\text { diorite. } \\
\text { NH-WQd-56-J-16. } \\
\text { Lake Winnepesau- } \\
\text { kee quadrangle, } \\
\text { New Hampshire. } \\
\text { H. W. Jaffe and } \\
\text { J. B. Lyons. }\end{array}$ & Zircon & $\begin{array}{r}-80+200 \\
-200+400\end{array}$ & $\begin{array}{l}353 \\
391\end{array}$ & $\begin{array}{l}38,40 \\
(39) \\
45,47 \\
(46)\end{array}$ & $\begin{array}{l}269 \\
285\end{array}$ & $\begin{array}{c}\text { Late Devonian(?) } \\
\text { (Billings, 1956). }\end{array}$ \\
\hline $\begin{array}{l}\text { Katahdin granite. } \\
\text { AB-2. } \\
\text { Ripogenus dam, } \\
\text { Maine. } \\
\text { A. J. Boucot. }\end{array}$ & $\ldots$ do & $\begin{array}{r}-80+200 \\
-200+400\end{array}$ & $\begin{array}{l}212 \\
230\end{array}$ & $\begin{array}{l}28 \\
30\end{array}$ & $\begin{array}{l}320 \\
316\end{array}$ & $\begin{array}{l}\text { Post-Early Devonian } \\
\text { (Boucot, 1954). }\end{array}$ \\
\hline $\begin{array}{l}\text { Gray granite. } \\
\text { A B-6. } \\
\text { Pocologan Harbor, } \\
\text { Charlotte County, } \\
\text { New Brunswick, } \\
\text { Canada. } \\
\text { A. J. Boucot. }\end{array}$ & ...do.......... & $\begin{array}{l}-80+200 \\
-200+400 \\
-400\end{array}$ & $\begin{array}{l}164 \\
229 \\
232\end{array}$ & $\begin{array}{l}24,26 \\
(25) \\
34,33 \\
(34) \\
34,36 \\
(35)\end{array}$ & $\begin{array}{l}368 \\
354 \\
364\end{array}$ & $\begin{array}{l}\text { Pre-Middle Silu- } \\
\text { rian(?) (A. J. } \\
\text { Boucot, written } \\
\text { communication, } \\
\text { 1956). }\end{array}$ \\
\hline $\begin{array}{l}\text { Granite } \\
\text { SG-1. } \\
\text { Giant's Range near } \\
\text { Mount Iron, } \\
\text { Minn. } \\
\text { G. M. Schwartz. }\end{array}$ & ....do do....... & $\begin{array}{r}-80+200 \\
-200+400\end{array}$ & $\begin{array}{l}393 \\
420\end{array}$ & $\begin{array}{c}233,236 \\
(235) \\
229,233 \\
(231)\end{array}$ & $\begin{array}{l}1,310 \\
1,220\end{array}$ & $\begin{array}{l}\text { Precambrian (Al- } \\
\text { goman?) (G. M. } \\
\text { Schwartz, written } \\
\text { communication, } \\
\text { 1956). }\end{array}$ \\
\hline $\begin{array}{l}\text { Granite. } \\
\text { M-3655. } \\
\text { Saganaga batho- } \\
\text { lith, Sea Gull } \\
\text { Lake, Cook } \\
\text { Co'mty, Minn. } \\
\text { G. M. Schwartz. }\end{array}$ & ... do...... & $\begin{array}{l}-80+200 \\
-200+400\end{array}$ & $\begin{array}{l}63 \\
62\end{array}$ & $\begin{array}{l}57,57,59 \\
(58) \\
53,54 \\
(54)\end{array}$ & $\begin{array}{l}1,900 \\
1,800\end{array}$ & $\begin{array}{l}\text { Precambrian (Lau- } \\
\text { rentian) (G. M. } \\
\text { Schwartz, written } \\
\text { communication, } \\
\text { 1956). }\end{array}$ \\
\hline
\end{tabular}

1 The figures in parentheses are the averages used in deriving the calculated ages.

\section{COMPARISON WITH OTHER METHODS}

Independent evidence concerning the reliability of the lead-alpha method can be obtained in two of the following ways:

1. Comparing the lead-alpha age with the geologic age of igneous rocks whose position in the geologic time scale is fairly well known on the basis of stratigraphic-paleontologic evidence. In this manner it can be determined whether the age measurements are correct with regard to their relative value.

2. Comparing the lead-alpha ages with concordant ages obtained by isotopic $\mathrm{Pb}^{206}: \mathrm{U}^{238}, \mathrm{~Pb}^{207}: \mathrm{U}^{235}, \mathrm{~Pb}^{207}: \mathrm{Pb}^{206}, \mathrm{Sr}^{87}: \mathrm{Rb}^{87}$, and $\mathrm{Ar}^{40}: \mathrm{K}^{40}$ methods. These comparisons would give information as to the absolute value of the ages inasmuch as different minerals containing different parent and daughter isotopes are used in two of the other methods. 


\section{IEAD-ALPHA AGES OF SOME IGNEOUS ROCKS YOUNGER THAN PRECAMBRIAN}

In order to compare lead-alpha ages with those obtained by geologic methods many age measurements have been made on minerals from suites of igneous rocks whose age can be assigned to different parts of the geologic time scale after the Precambrian. Within this segment of geologic time, relative geochronology has been established primarily by stratigraphic-paleontologic methods. Lead-alpha ages on some series of rocks ranging in age from late Tertiary to early Paleozoic are listed in table 21. In several localities the geologic time relations between fossiliferous sediments and the igneous rocks are accurately known within fairly narrow limits. For most of the other igneous rock series, the assigned geologic ages are probably correct. Generally, the average ages obtained for a related series of igneous rocks by the lead-alpha method fall in the same sequence as the geologic age of the rocks and are correct as to relative value.

Those localities containing rocks that are suitable for establishing physical time points in the geologic column are as follows:

1. San Juan Mountains, Colo. Extrusive and intrusive rocks of the Potosi volcanic series and Fisher quartz latite are of Miocene age on the basis of fossil plants and insects from the Creede formation (Larsen and Cross, 1956).

2. Cerillos Hills, N. Mex. Stocks intrude the Galisteo and Espinaso formations of late Eocene age and are overlain by Abiquiu (?) formation of early Miocene age (Stearns, 1953).

3. Tintic district, Utah. Plant fossils of Green River age (middle Eocene) are found in fresh-water limestone interlayered with agglomerates which are correlated with the intrusive rocks (T. S. Lovering and H. T. Morris, written communication, 1956).

4. Bearpaw Mountains, Mont. Volcanic rocks overlie the Wasatch formation (early Eocene) and are interlayered with tuffaceous sediments containing plant and vertebrate fossils of Green River age (middle Eocene) (Brown and Pecora, 1949).

5. Alberta, Canada, Kneehills tuff lies in the upper part of the Edmonton formation, which contains a dinosaurian fauna, of Maestrichtian age (Late Cretaceous), and is overlain by Paskapoo beds of Tertiary (probably Paleocene) age (Folinsbee and others, 1957).

6. Baja California. Granitic rocks intrude the San Telmo formation of Albian age (late Early Cretaceous) and are overlain by the Rosario formation of Maestrichtian age (Late Cretaceous) (Silver, and others, 1956, and Woodford and Harris, 1938). 
7. New Hampshire plutonic series, New Hampshire. Intrusive rocks are younger than the Littleton formation (Devonian) and older than the Moat volcanics of possible Mississippian age (Billings, 1956).

8. St. George, New Brunswick, Canada. Granite intrudes the Eastport formation (Late Silurian and possibly Early Devonian) and is overlain unconformably by the Perry formation which contains Late Devonian fossils and cobbles of the granite.

9. Oliverian plutonic series. Intrusive rocks are younger than Clough quartzite (Early or Middle Silurian) and may be younger than the Littleton formation (Middle Devonian) (Billings, 1956).

10. Highlandcroft plutonic series, New Hampshire. Intrusives are younger than the Ammonoosuc volcanics (Late Ordovician?) and older than the Fitch formation (Middle Silurian) (Billings, 1956).

11. Strasburg, Virginia. Tuff 7 feet above base of Martinburg shale of Middle and Late Ordovician age.

The average lead-alpha age on accessory minerals of rocks from these localities are plotted in figure 6 on the Holmes' $B$ time scale (Holmes, 1947). Considering the uncertainty as to the geologic age of some of the minerals used by Holmes and the uncertainties inherent in the lead-alpha method, the agreement is highly satisfactory.

The experimental data from which all the lead-alpha ages have been calculated are given by Jaffe and others (1959). The geologic significance of the age measurements for the rocks of New England are discussed in detail by Lyons and others (1957), Quinn and others (1957), and for the Mesozoic batholiths of western North America by Larsen and Schmidt (1958) and Larsen and others (1958).

\section{LEAD-ALPHA VERSUS ISOTOPIC IEAD AGES}

Application by Tilton and others (1957) of the isotope dilution method of analysis for the determination of small amounts of uranium, thorium, and lead has made possible the determination of ages on zircon from the ratios $\mathrm{Pb}^{208}: \mathrm{U}^{238}, \mathrm{~Pb}^{207}: \mathrm{U}^{235}, \mathrm{~Pb}^{208}: \mathrm{Th}^{232}$, and $\mathrm{Pb}^{207}: \mathrm{Pb}^{208}$. Comparisons of lead-alpha and isotopic ages obtained either on the same material or on samples from related rocks are given in table 22. Ages obtained from the isotopic ratios are frequently discordant and usually show the pattern $\mathrm{Pb}^{208}: \mathrm{Th}^{232}<\mathrm{Pb}^{206}: \mathrm{U}^{238}$ $<\mathrm{Pb}^{207}: \mathrm{U}^{235}<\mathrm{Pb}^{207}: \mathrm{Pb}^{206}$. When these ages agree to within some specified limit, about \pm 10 percent of each other, they are said to be concordant. An example of concordancy in table 22 is shown by the excellent agreement of the four isotopic ages obtained on zircon from Ceylon and a typical discordant pattern is shown by the isotopic data 


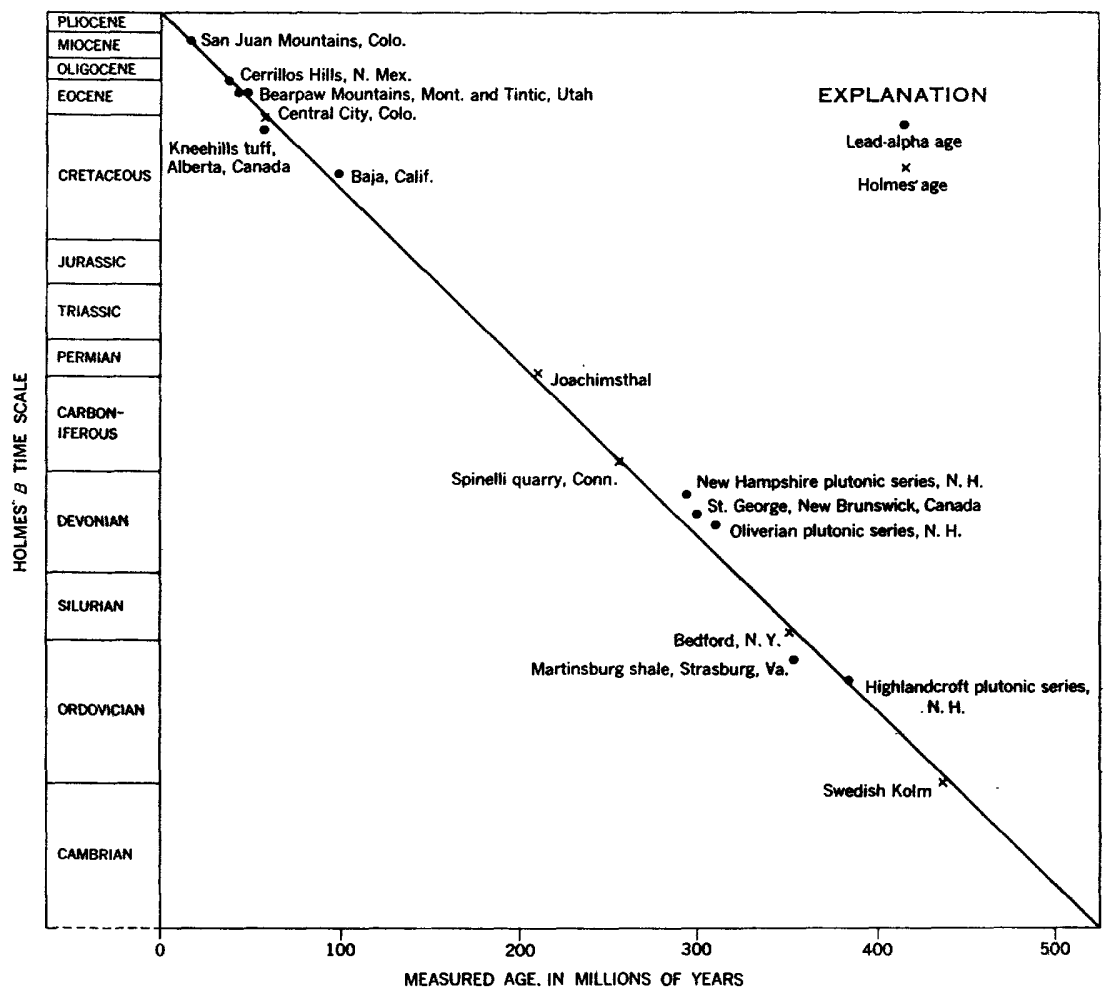

FIGURE 6.-Lead-alpha ages of accessory minerals from igneous rocks of known geologic age compared with Holmes' $B$ time scale.

on zircon from the Pikes Peak granite of Colorado. The $\mathrm{Pb}^{208}: \mathrm{Th}^{232}$ ages are often considerably low even when the other three ages are in close agreement as is shown for the zircon from the granite from Tory Hill, Canada. Discordant ages are most commonly attributed to the following causes:

1. Differential loss or gain of uranium, thorium, and lead.

2. Presence of common and old radiogenic lead.

3. Loss of radon.

4. Errors in experimental techniques.

Any of these causes will have effects of different orders of magnitude on a given lead ratio or discordant age pattern; they are discussed in detail by Kulp and others (1954), Kulp and Eckelmann (1957), Stieff and Stern (1956), and Faul (1954). The effect of recent alteration causing a loss of lead, uranium, thorium, or radon is much less for the $\mathrm{Pb}^{207}: \mathrm{Pb}^{206}$ ratio than for the $\mathrm{Pb}^{206}: \mathrm{U}^{238}$ and $\mathrm{Pb}^{208}: \mathrm{Th}^{232}$ ratios. However, the $\mathrm{Pb}^{207}: \mathrm{Pb}^{206}$ ratio is most sensitive to mass spectrometric errors and to the presence of original lead. When the $\mathrm{Pb}^{207}: \mathrm{Pb}^{206}$ ages are greater than the $\mathrm{Pb}^{206}: \mathrm{U}^{238}$ ages the pattern can 
TABLE 21.-Lead-alpha ages of some igneous rocks younger than Precambrian

\begin{tabular}{|c|c|c|c|c|c|}
\hline Locality & $\begin{array}{l}\text { Number } \\
\text { of rocks }\end{array}$ & $\begin{array}{c}\text { Number } \\
\text { of deter- } \\
\text { minations }\end{array}$ & $\begin{array}{l}\text { Range } \\
\text { (millions } \\
\text { of years) }\end{array}$ & $\begin{array}{c}\text { Mean } \\
\text { age and } \\
\text { standard } \\
\text { deviation } \\
\text { (millions } \\
\text { of years) }\end{array}$ & $\begin{array}{l}\text { Probable geologic } \\
\text { age }\end{array}$ \\
\hline $\begin{array}{l}\text { San Juan Mountains, Colo. (Hinsdale } \\
\text { formation). }\end{array}$ & 1 & 1 & & 15 & Pliocene(?). \\
\hline $\begin{array}{l}\text { San Juan Mountains, Colo } \\
\text { Santa Fe County, N. Mex } \\
\text { Marion County, Oreg } \\
\text { Iron Springs, Utah. }\end{array}$ & $\begin{array}{l}8 \\
1 \\
1 \\
3\end{array}$ & $\begin{array}{r}10 \\
1 \\
1 \\
3\end{array}$ & $10-24$ & $\begin{array}{l}18 \pm 5 \\
18 \\
23 \\
23 \pm 5\end{array}$ & $\begin{array}{l}\text { Miocene. } \\
\text { Do. } \\
\text { Do. } \\
\text { Oligocene or }\end{array}$ \\
\hline $\begin{array}{l}\text { Lane County, Oreg } \\
\text { Cerrillos Hills, N. Mex }\end{array}$ & 1 & $\begin{array}{l}1 \\
4\end{array}$ & $32-46$ & $\begin{array}{l}37 \\
40 \pm 7\end{array}$ & $\begin{array}{l}\text { Do. } \\
\text { Oligocene. }\end{array}$ \\
\hline Tintic, Utah & 2 & 4 & $39-50$ & $45 \pm 5$ & Middle Eocene. \\
\hline $\begin{array}{l}\text { Bearpaw Mountains, Mont } \\
\text { Humacao, Puerto Rico } \\
\text { Alberta, Canada }\end{array}$ & $\begin{array}{l}1 \\
2 \\
1\end{array}$ & $\begin{array}{l}2 \\
3 \\
1\end{array}$ & $\begin{array}{l}46-46 \\
53-58\end{array}$ & $\begin{array}{l}46 \pm 0 \\
55 \pm 2 \\
53\end{array}$ & $\begin{array}{l}\text { Do. } \\
\text { Eocene(?). } \\
\text { Late Cretaceous. }\end{array}$ \\
\hline Boulder batholith, Mont & 7 & 8 & $63-76$ & $71 \pm 4$ & $\begin{array}{l}\text { Late Cretaceous- } \\
\text { pre-Oligocene. }\end{array}$ \\
\hline Baja California, Mexico . . & 6 & 6 & $96-112$ & $101 \pm 5$ & Early Late \\
\hline $\begin{array}{l}\text { Southern California batholith, Cali- } \\
\text { fornia. }\end{array}$ & 25 & 27 & $92-136$ & $110 \pm 13$ & Do. \\
\hline Sierra Nevada batholith, California.... & 15 & 20 & $81-123$ & $102 \pm 11$ & $\begin{array}{l}\text { Late Jurassic or } \\
\text { Cretaceous. }\end{array}$ \\
\hline Idabo batholith, Idaho & 17 & 21 & $90-135$ & $108 \pm 12$ & Cretaceous. \\
\hline $\begin{array}{l}\text { Coast Range batboliths, Washington, } \\
\text { British Columbia, and Alaska. }\end{array}$ & 16 & 23 & $92-134$ & $105 \pm 13$ & $\begin{array}{l}\text { Late Jurassic or } \\
\text { Cretaceous. }\end{array}$ \\
\hline $\begin{array}{l}\text { Wbite Mountain plutonic volcanic } \\
\text { series, New Hampshire. }\end{array}$ & 5 & 12 & 171-212 & $186 \pm 14$ & Mississippian(?). \\
\hline $\begin{array}{l}\text { Westrrly granite and related rocks, } \\
\text { Rhode Island. }\end{array}$ & 6 & 6 & $208-274$ & $234 \pm 23$ & $\begin{array}{l}\text { Late or post- } \\
\text { Carboniferous. }\end{array}$ \\
\hline $\begin{array}{l}\text { Quincy granite and related rocks, } \\
\text { Rhode Island and Massacbusetts. }\end{array}$ & 2 & 5 & $257-275$ & $270 \pm 7$ & Mississippian(?). \\
\hline $\begin{array}{l}\text { Scituate granite gneiss and related } \\
\text { rocks, Rhode Island. }\end{array}$ & 4 & 5 & 289-337 & $306 \pm 18$ & Devonian(?) or \\
\hline $\begin{array}{l}\text { New Hampshire plutonic series, New } \\
\text { Hampshire. }\end{array}$ & 8 & 12 & $266-346$ & $296 \pm 29$ & Late Devonian(?). \\
\hline $\begin{array}{l}\text { Granite, St. George, New Brunswick, } \\
\text { Canada. }\end{array}$ & 1 & 1 & & 301 & Middle Devonian. \\
\hline Katahdin granite, Maine................ & 1 & 2 & $316-320$ & $318 \pm 2$ & Post Early \\
\hline $\begin{array}{l}\text { Oliverian plutonic series, New Hamp- } \\
\text { shire. }\end{array}$ & 5 & 5 & $287-337$ & $311 \pm 26$ & $\begin{array}{l}\text { Middle or Late } \\
\text { Devonian(?). }\end{array}$ \\
\hline Littleton, New Hampshire & 1 & 1 & & 298 & Early and Middle \\
\hline Tuff in Martinsburg shale, Virginia... & 1 & 1 & & 353 & Middle and Late \\
\hline $\begin{array}{l}\text { Highlandcroft plutonic series, New } \\
\text { Hampshire. }\end{array}$ & 4 & 4 & $368-425$ & $385 \pm 27$ & Late Ordovician. \\
\hline
\end{tabular}

be attributed to either the loss of lead or radon or the gain of uranium, provided original lead is not a major factor. Thus, a single discordant age pattern provides no information as to which of the causes has played a predominant role.

The amount of uranium in zircon is, in general, nearly equal to or else greater than the amount of thorium present. Inasmuch as a given amount of uranium produces about four times the alpha activity as the same amount of thorium, most of the radiogenic lead in zircon is $\mathrm{Pb}^{206}$. Thus, the lead-alpha ages can be considered essentially $\mathrm{Pb}^{206}: \mathrm{U}^{238}$ ages. Close agreement between lead-alpha and $\mathrm{Pb}^{208}: \mathrm{U}^{238}$ ages has been obtained on most zircon samples from Conway, N.H.; Ceylon; Wichita Mountains, Okla.; Pikes Peak, Colo.; Llano County, Tex.; Tory Hill, Canada; and Bodom, Finland. The wide discrepancy between the lead-alpha and the $\mathrm{Pb}^{206}: \mathrm{U}^{238}$ age on the zircon 


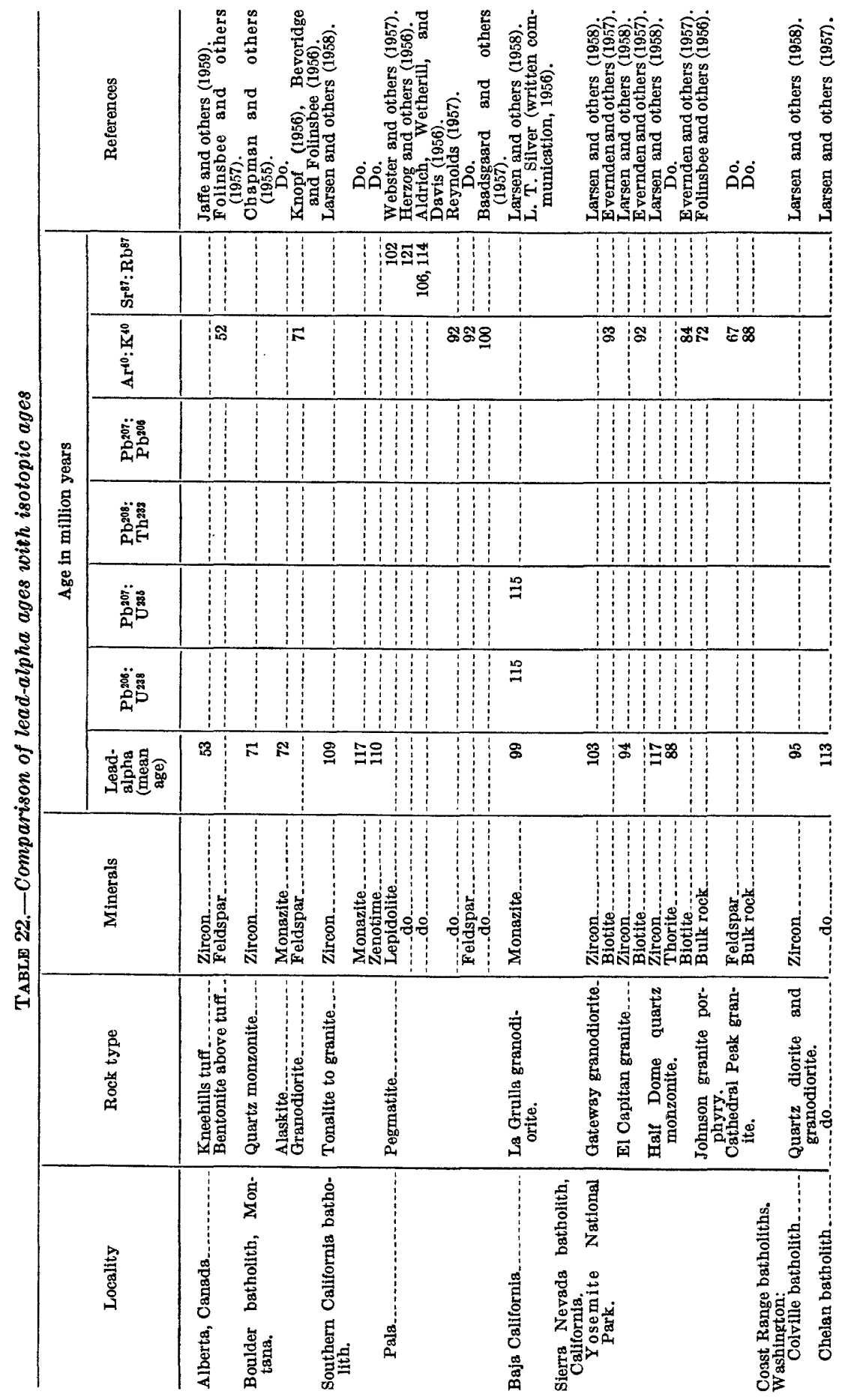




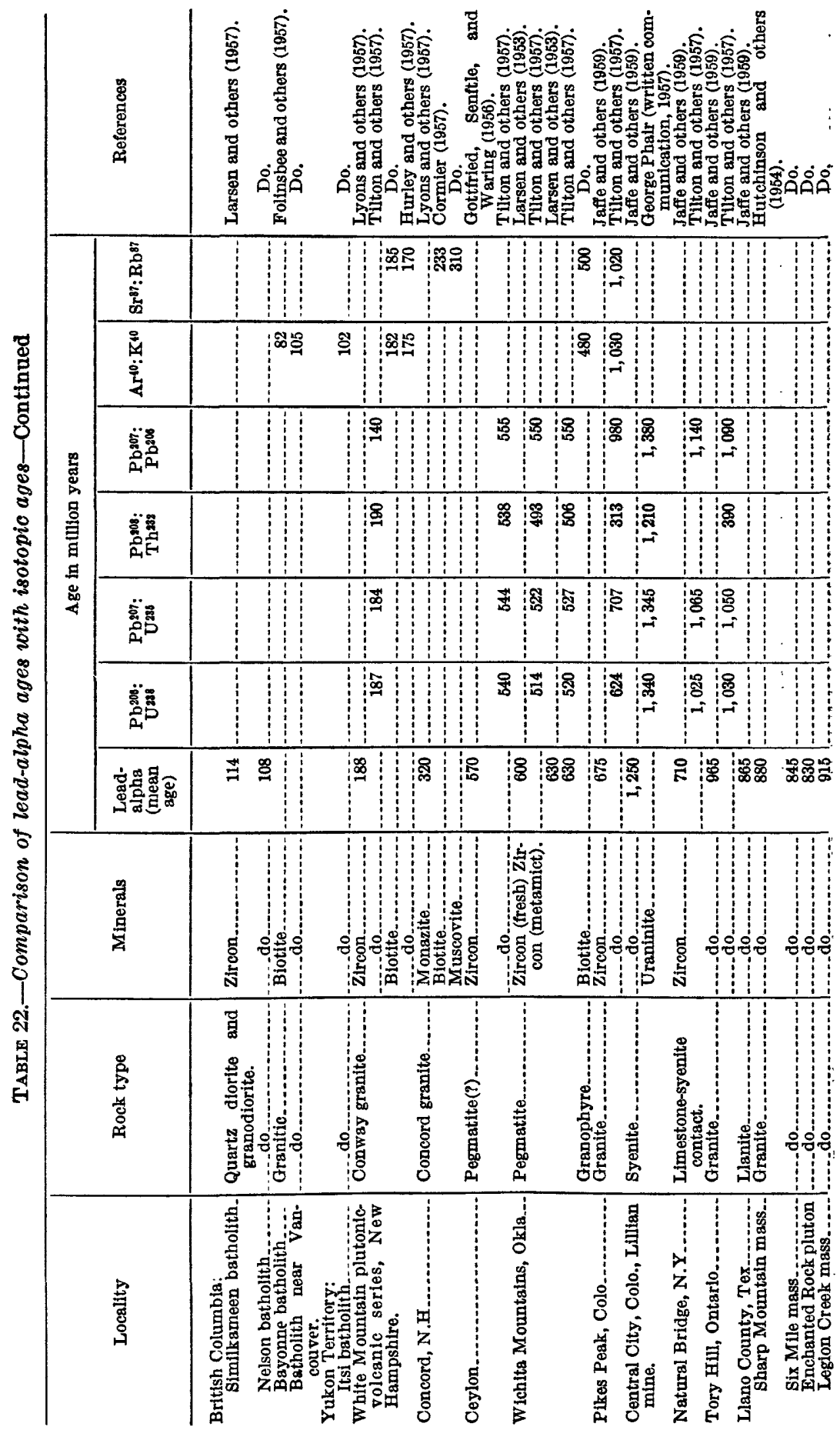




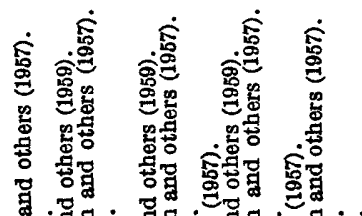

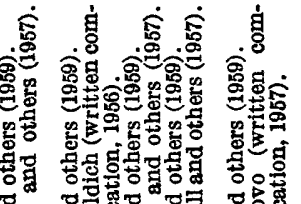

ค่

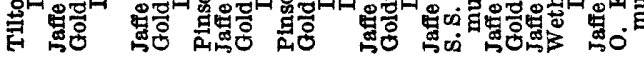

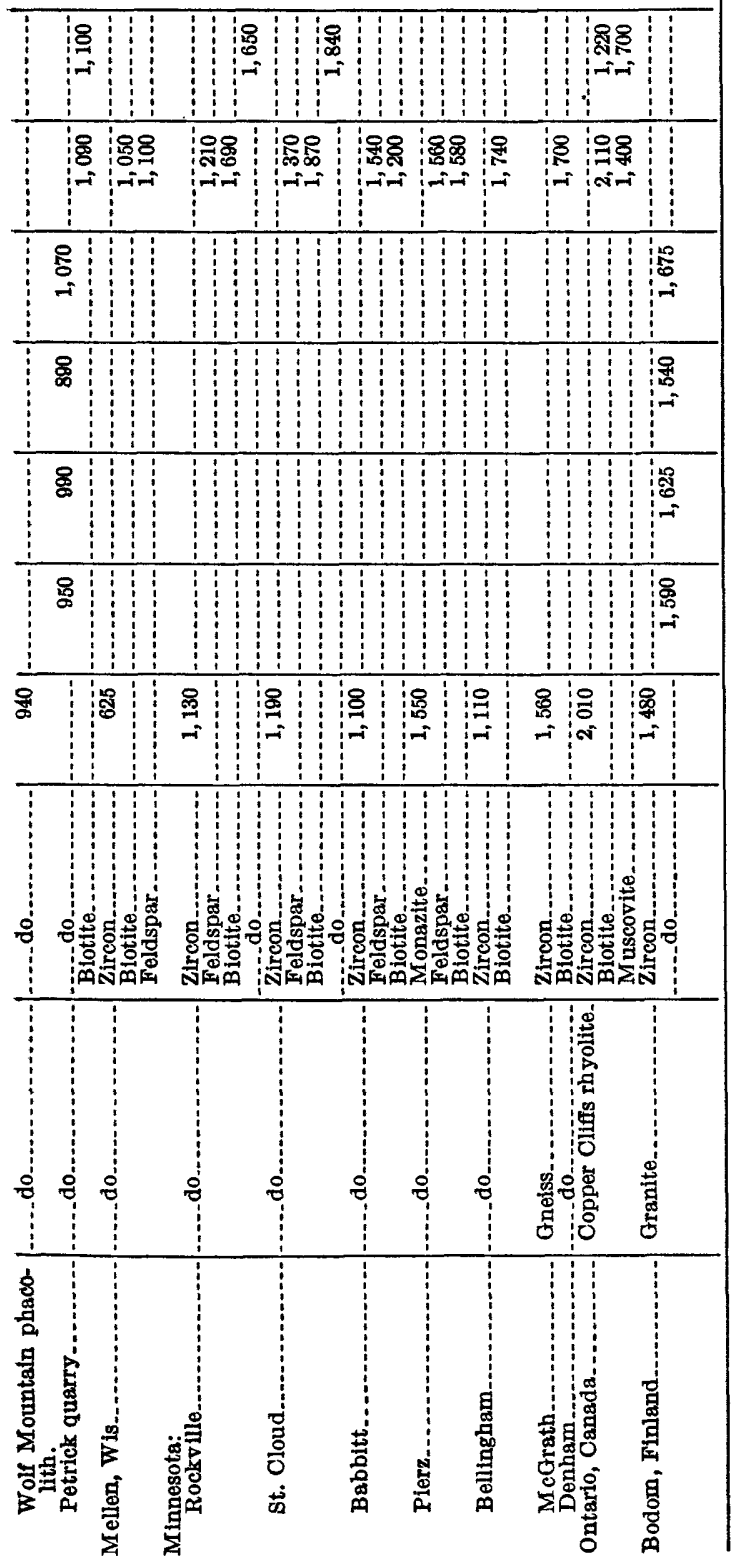


from Natural Bridge, N.Y., is due to a discrepancy in the results of the lead analyses of the sample. A content of $127 \mathrm{ppm}$ of lead was obtained by Tilton by isotope dilution as against $66 \mathrm{ppm}$ determined repeatedly by emission spectrographic analyses on splits of the same material. Further work is in progress to determine the cause of this discrepancy. The lead-alpha age on monazite from a granitic rock from Baja California is in satisfactory agreement with the preliminary isotopic lead-uranium ages reported to the writers by L. T. Silver (California Inst. Technology, written communications). In order to make a proper comparison between the two methods the $\mathrm{Pb}^{208}: \mathrm{Th}^{232}$ age is necessary. This determination has not yet been made.

A Precambrian syenite from the Lillian mine near Central City, Colo., contained both zircon and uraninite. There can be little doubt that these minerals are cogenetic inasmuch as crystals of uraninite are present as inclusions in many zircon crystals (plate 1 ). The leadalpha age obtained on hand-picked zircon crystals free of uraninite, agreed to within 10 percent of the concordant isotopic ages on uraninite obtained by George Phair (written communication).

Tilton and others (1957) have shown that isotopic ages on most zircon containing significant amounts of original lead are badly discordant and that concordant ages were obtained on nearly all samples for which original lead was not detected. However, for most zircon samples the lead-alpha ages, which are based on total lead content, are in close agreement with the $\mathrm{Pb}^{206}: \mathrm{U}^{238}$ ages for which corrections for original lead have been applied. These checks indicate the relatively minor effect of the presence of original lead on the lead-alpha ages, and that if the presence of original lead were the major cause for discordant ages in zircon, then the $\mathrm{Pb}^{207}: \mathrm{Pb}^{206}$ ratios would show ages much greater than the probable true age. The difficulties in interpreting discordant age patterns have yet to be resolved and the choice of any of the individual ages will continue to be largely speculative unless independent evidence is brought to bear on the problem.

\section{IEAD-ALPHA VERSUS Ar40: $\mathbf{K}^{40}$ AND Sr ${ }^{87}: \mathbf{R b}^{87}$ AGES}

The decay of the radioactive istopes of the alkali metals $K^{40}$ and $\mathrm{Rb}^{87}$ to $\mathrm{Ar}^{40}$ and $\mathrm{Sr}^{87}$, respectively, provides methods for measuring the age of potassium and rubidium bearing minerals. The decay schemes are as follows: $K^{40}$ decays both by beta emission to $\mathrm{Ca}^{40}$ and by electron capture to $\mathrm{Ar}^{40} ; \mathrm{Rb}^{87}$ decays by beta emission to $\mathrm{Sr}^{87}$. Recent measurements of the decay constants used for the $\mathbf{A r}^{40}: \mathbf{K}^{40}$ ages have been published by Wetherill and others (1956), and for the $\mathrm{Sr}^{87}: \mathrm{Rb}^{87}$ ages by Aldrich and others (1956). They were obtained primarily by comparing the $A r^{40}: K^{40}$ and $\mathrm{Sr}^{87}: \mathrm{Rb}^{87}$ ratios in micas against concordant lead-uranium ages on uraninite from the same 

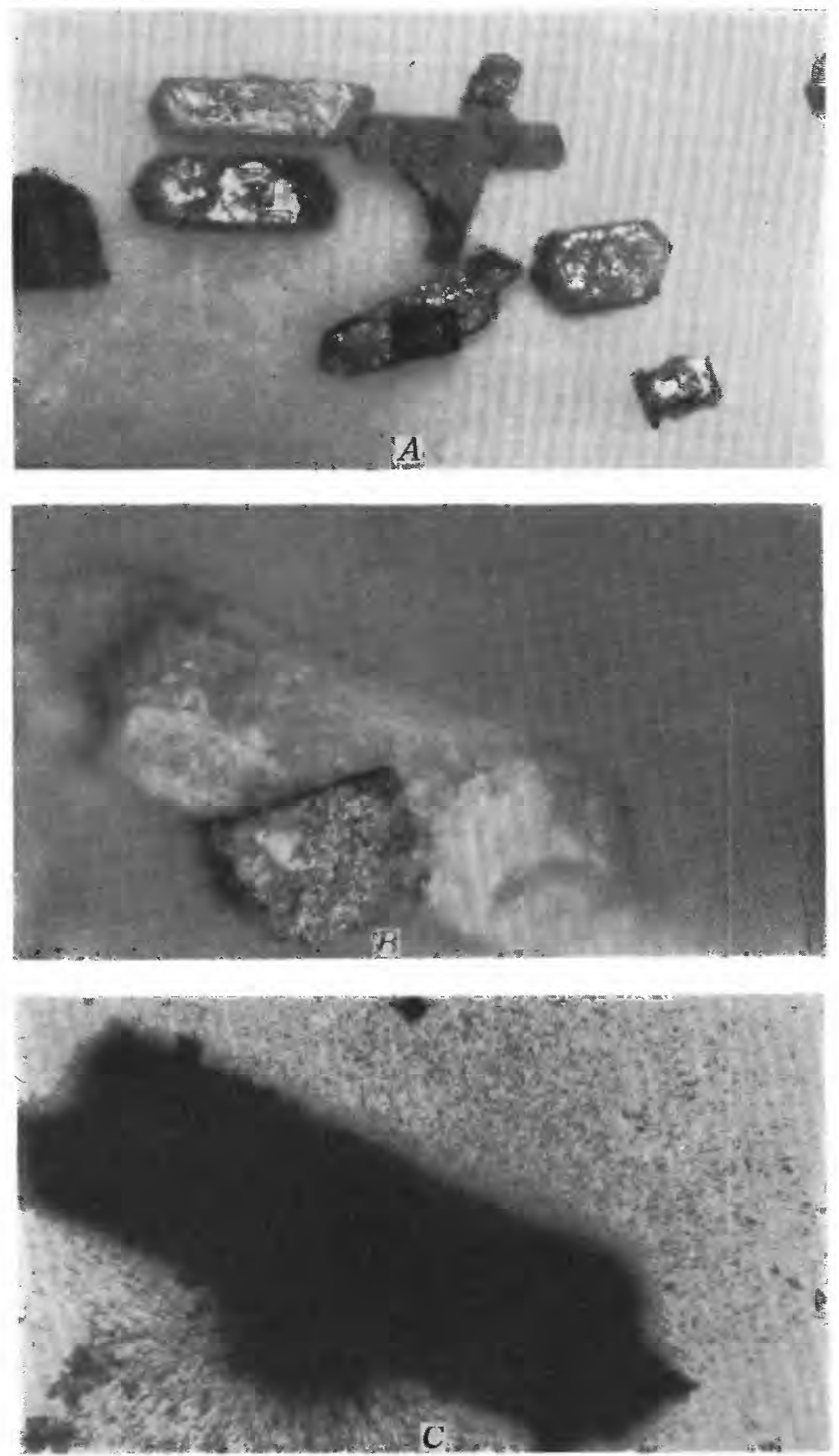

ZIRCON CRYSTALS FROM SYENITE, LILLIAN MINE, CENTRAL CITY, COLORADO

$A$, Zircon crystals at low magnification $(\times 50)$ showing uraninite (black crystal at center) intergrown with zircon. $B$, Intergrown zircon-uraninite crystal at high magnification $(X 150)$. $C$, Autoradiograph of same crystal showing alpha tracks emanating from uraninite. 

geologic setting. Using this method, the decay constant for electron capture for $K^{40}$ and the branching ratio were found to be $0.557 \pm 0.026 \times 10^{-10} \mathrm{yr}^{-1}$ and $0.117 \pm 0.015$, respectively, and the halflife of $\mathrm{Rb}^{87}$ to be $5.0 \pm 0.2 \times 10^{10}$ years. By virtue of the close agreement of these values with those obtained by laboratory counting experiments it seems that the decay constants are not seriously in error. Inasmuch as each alkali metal parent isotope, $R^{87}$ and $\mathbf{K}^{\mathbf{4 0}}$, decays to chemically different daughter products, one an alkaline earth metal, and the other a noble gas, concordant $A r^{40}: K^{40}$ and $\mathrm{Sr}^{87}: \mathrm{Rb}^{87}$ mica ages should be close to the absolute ages of these minerals and provide an independent means of evaluating the leadalpha and isotopic ages obtained on zircon and other accessory minerals from the same or related rocks.

Comparison of lead-alpha ages with published $\mathrm{Ar}^{40}: \mathbf{K}^{40}$ and $\mathrm{Sr}^{87}$ : $\mathrm{Rb}^{87}$ ages are given in table 22 . The same constants have now been adopted by other investigators so that the $\mathrm{Ar}^{40}: \mathrm{K}^{40}$ and $\mathrm{Sr}^{87}: \mathrm{Rb}^{87}$ ages from different laboratories are comparable in this respect. Wetherill and others (1955), Folinsbee and others (1956), and Carr and Kulp (1957) have found discrepancies between the $A r^{40}: K^{40}$ ages on mica and feldspar and have shown that, in general, micas retain more argon than the feldspars.

Close agreement between the lead-alpha zircon age (53 million years) and the feldspar age (52 million years) has been obtained for the Kneehills tuff and between the lead-alpha ages (72 million years) and feldspar age (71 million years) for the Boulder batholith of Montana. However, Knopf (1956) favors a calculated age of 87 million years (based on a branching ratio of 0.089 ) on the grounds of argon leakage for the feldspar from the Boulder batholith. Age measurements on micas from these rocks are clearly needed to determine whether or not there has been a loss of argon from these feldspars.

A large number of lead-alpha age determinations have been obtained on accessory minerals from rocks of the batholith of southern California (Larsen and others, 1958). Isotopic ages have not been determined on minerals from the major rock types, but have been made on feldspar and lepidolite from the pegmatites at Pala, Calif. The pegmatites are genetically related to the batholith (Larsen, 1948) and the average lead-alpha ages obtained on zircon (109 million years), monazite (117 million years), and xenotime (110 million years) from the igneous rocks are in satisfactory agreement with $A r^{40}: K^{40}$ feldspar and lepidolite ages (92 and 100 million years) and $\mathrm{Rb}^{87}$ : $\mathrm{Sr}^{87}$ ages ranging from 102 to 121 million years. Lead-alpha ages obtained on granitic rocks of the Sierra Nevada batholith and Coast Range batholiths are principally the same as those obtained on 
rocks of southern California. Comparisons of lead-alpha with $\mathrm{Ar}^{40}: \mathrm{K}^{40}$ biotite ages can be made for three rocks from Yosemite $\mathrm{Na}$ tional Park. Zircon from the 3 rocks gave lead-alpha ages of 103, 94, and 117 million years as compared to mica ages of 93,92 , and 84 million years. Thorite from one of these rocks gave a lead-alpha age of 88 million years. The $A r^{40}: \mathrm{K}^{40}$ ages determined on two samples of bulk granitic rock and a feldspar phenocryst from the same area gave ages of 67,72 , and 88 million years; these low values may result from argon leakage. The lead-alpha ages on zircon from scattered intrusive masses of the Coast Range batholith check closely with three $A r^{40}: K^{40}$ ages on biotite from other intrusive bodies of this batholith.

Age measuremnts by each of the methods discussed have been made on granitic rocks from Conway, N.H.; Pikes Peak, Colo., and Llano County, Tex. The lead-alpha age (188 million years) and isotopic lead-uranium ages on the zircon $(187,184$ million years) from the Conway granite are in remarkably close agreement with the $\mathrm{Ar}^{40}: \mathbf{K}^{\mathbf{4 0}}$ (175 and 182 million years) and $\mathrm{Sr}^{87}: \mathrm{Rb}^{87}$ (170 and 185 million years) ages obtained on biotite in two different laboratories (Tilton and others 1957, Hurley and Fairbairn 1957).

In contrast to the agreement for most of the lead-alpha ages with ages determined by other methods on minerals younger than Precambrian, most of the lead-alpha ages on Precambrian rocks are not in good agreement with $\mathrm{Ar}^{40}: \mathrm{K}^{40}$ and $\mathrm{Sr}^{87}: \mathrm{Rb}^{87}$ ages. The age data on the Pikes Peak granite show the general pattern which is repeated in other Precambrian localities. The lead-alpha age (675 million years) is closest to the lead-uranium isotopic ages (624 and 707 million years), whereas the $\mathrm{Pb}^{207}: \mathrm{Pb}^{206}$ age (980 million years) checks more closely with $\mathrm{Ar}^{40}: \mathrm{K}^{40}$ (1,030 million years) and $\mathrm{Sr}^{87}: \mathrm{Rb}^{87}$ (1,020 million years) ages for the biotite. In nearly every case where the lead-alpha ages failed to agree with the biotite ages the lead-alpha ages were low. The differences found were as follows: nearly 10 percent low for the granite from Babbitt and McGrath gneiss, about 20 percent for the granitic rocks from Texas, and from 30 to 40 percent on samples from Pikes Peak, Mellen, Rockville, St. Cloud, and Bellingham. Although $\mathrm{Sr}^{87}: \mathrm{Rb}^{87}$ and $\mathrm{Ar}^{40}: \mathrm{K}^{40}$ ages on mica are usually in very close agreement, wide age discrepancies have been found on both muscovite and biotite from the Copper Cliff rhyolite of Phemister (1957), and the Concord granite. In both of these cases the lead-alpha ages agreed most closely with the highest ages obtained on the micas.

\section{SUMMARY AND CONCLUSIONS}

The data given in this report permit an evaluation of the limitations of the lead-alpha age method and its applicability to geologic problems. Sources of error include: experimental errors of the alpha 
counts and lead determinations; presence of original lead; variations from the assumed thorium-uranium ratios; possible susceptibility of minute zircon crystals to loss or gain of thorium, uranium, or lead by diffusion, leaching, or metamorphism; and application of the simplified age equations to rocks older than Cambrian. With regard to analytical techniques, the largest source of error is in the lead analyses, especially in zircon that contains only a few parts per million of lead. For zircon and other minerals that contain more than $10 \mathrm{ppm}$ of lead, the content of lead can be measured with a precision of \pm 6 to 10 percent. Agreement between the alpha emission measured by thicksource alpha counting and that calculated from the uranium and thorium content of zircon and monazite indicates that the alpha activity measurements have an accuracy of about \pm 5 percent.

Where the method has been applied to a relatively large suite of cogenetic rocks younger than Precambrian, the scatter pattern of the age data is what would be expected from the experimental errors. In general, the standard deviation from the mean age is about 10 percent or less for minerals from rocks older than Cretaceous and younger than Precambrian. For younger rocks, which contain zircon with a very low lead content, the percent error is much greater but is generally less than 10 million years.

Inasmuch as zircon, monazite, thorite, and xenotime from the same or related rocks give ages which generally agree within the limits of error of the method, it has been shown that errors in the assumptions with regard to original lead and the loss or gain of parent and daughter products do not contribute significantly to the errors in the ages for most of the rocks, younger than Precambrian, tested.

Age determinations have been made on many geologically well dated igneous rocks in order to test the validity of the method by using geologic evidence. With few exceptions, the age data agree with the geologic sequence of events and hence the method can be used for distinguishing the ages of igneous rocks provided their age difference is not within the limits of error of the method. The lead-alpha ages on these samples are in close agreement with the lead-uranium ages on minerals that are probably of equivalent geologic age and form the basis of the Holmes time scale (Holmes, 1947).

Comparison of ages by the lead-alpha method has been made on zircon and monazite on which isotopic ages have been determined; zircon closely associated with isotopically dated uraninite; and on zircon and monazite from the same or related rocks for which argonpotassium and strontium-rubidium ages are available. In view of the paucity of the data the following conclusions regarding the cross checks are tentative:

1. The lead-alpha ages determined on zircon are primarily equivalent to the $\mathrm{Pb}^{208}$ : $\mathrm{U}^{238}$ ages. 
2. When concordant lead-uranium and $\mathrm{Pb}^{207}: \mathrm{Pb}^{206}$ ages are obtained, the lead-alpha ages are generally in close agreement with the isotopic ages regardless of their geologic age.

3. When a discordant age pattern is obtained, the $\mathrm{Pb}^{206}: \mathrm{U}^{238}$ and hence the lead-alpha ages are lower than the $\mathrm{Pb}^{207}: \mathrm{Pb}^{206}$ age; the last, in general, is in closest agreement with the strontiumrubidium and argon-potassium ages obtained on micas.

4. In general, the lead-alpha ages agree with the isotopic, lead-uranium, argon-potassium and strontium-rubidium ages determined on minerals younger than Precambrian.

5. Often the lead-alpha ages are much lower than those obtained by the other methods on minerals from Precambrian rocks.

As yet, we have no satisfactory explanation for the wide age discrepancies obtained from the Precambrian rocks, but it seems likely that in some areas the minerals have lost lead by partial or complete recrystallization resulting from later metamorphic processes. Although considerable doubt exists in the interpretation of the results on Precambrian rocks, the lead-alpha method may yield useful information with regard to the postcrystallization history of a region even if its usefulness for dating the primary crystallization of minerals is restricted.

Fundamental studies are needed on a large number of carefully selected samples in order to correlate the age results with a complex geologic environment. Regardless of the method applied to the dating of minerals or rocks, the interpretation of the results from a geologic standpoint can be no better than our understanding of the history of a rock and its relationship to its geologic environment.

\section{LITERATURE CITED}

Ahrens, L. H., 1953, The use of ionization potentials, pt. 2, Anion affinity and geochemistry : Geochim. et Cosmochim. Acta, v. 3, p. 1-29.

Aldrich, L. T., Wetherill, G. W., and Davis, G. L., 1956, Determinations of radiogenic $\mathrm{Sr}^{87}$ and $\mathrm{Rb}^{87}$ of an interlaboratory series of lepidolites: Geochim. et Cosmochim. Acta, v. 10, p. 238-240.

Aldrich, L. T., Wetherill, G. W., Tilton, G. R., and Davis, G. L., 1956, Half-life of $\mathrm{Rb}^{87}$ : Phys. Rev., v. 103, p. 1045-1047.

Baadsgaard, H., Goldich, S. S., Nier, A. O., and Hoffman, J. H., 1957, The reproducibility of $\mathrm{A}^{40} / \mathrm{K}^{40}$ age determinations: Am. Geophys. Union Trans., v. 38, p. 539-542.

Beharrell, J., 1949, Absorption of alpha rays in thick sources: Am. Geophys. Union Trans., v. 30, p. 333-336.

Beveridge, A. J., and Folinsbee, R. E., 1956, Dating Cordilleran orogenies : Royal Soc. Canada Trans., v. 50, p. 19-43.

Billings, M. P., 1956, The geology of New Hampshire, pt. 2, Bedrock geology : New Hampshire State Plan. and Devel. Comm., Concord, 203 p.

Boucot, A. J., 1954, Age of the Katahdin granite [Maine] : Am. Jour. Sci., v. 252, p. 144-148. 
Brown, R. W., and Pecora, W. T., 1949, Paleocene and Eocene strata in the Bearpaw Mountains, Montana: Science, v. 109, p. 487-489.

Carr, D. R., and Kulp, J. L., 1957, Potassium-argon method of geochronometry : Geol. Soc. America Bull., v. 68, p. 763-784.

Chapman, R. W., Gottfried, David, and Waring, C. L., 1955, Age determinations on some rocks from the Boulder batholith and other batholiths of western Montana : Geol. Soc. America Bull., v. 66, p. 607-609.

Cormier, R. F., 1957, Comparison of $\mathrm{Rb} / \mathrm{Sr}$ ages measured for biotite and muscovite from the same rock sample: Mass. Inst. Technology, 4th Ann. Prog. Rept., NYO-3937, p. 72-74.

Davis, G. L., and others, 1957, The age of rocks and minerals: Carnegie Inst. of Washington, Ann. rept. of the Director of the Geophys. Lab., 1956-1957, p. 169.

Evernden, J. F., Curtis, G. H., and Lipson, J., 1957, Potassium-argon dating of igneous rocks: Am. Assoc. Petroleum Geologists Bull., v. 41, no. 9, p. 2120-2127.

Faul, Henry, 1954, Nuclear Geology: New York, John Wiley and Sons, Inc., $414 \mathrm{p}$.

Folinsbee, R. F., Lipson, J., and Reynolds, J. H., 1956, Potassium-argon dating: Geochim. et Cosmochim. Acta, v. 10, p. 60-68.

Folinsbee, R. E., Ritchie, W. D., and Stansberry, G. F., 1957, The Crowsnest volcanics and Cretaceous geochronology : Alberta Soc. Petroleum Geologists Guidebook, 7th Ann. Field Conf., Waterton, 1957, p. 20-26.

Goldich, S. S., Baadsgaard, H., and Nier, A. O., 1957, Investigations in $A^{10} / K^{10}$ dating: Am. Geophys. Union Trans., v. 38, p. 547-551.

Goldschmidt, V. M., 1954, Geochemistry: Oxford, Clarendon Press.

Gottfried, David, Senftle, F. E., and Waring, C. L., 1956, Age determination of zircon crystals from Ceylon: Am. Mineralogist, v. 41, p. 157-161.

Gottfried, David, Waring, C. L., Worthing, H. W., 1956, Hafnium content, hafnium to zirconium ratio, and radioactivity of zircon from igneous rocks [abs.] : Geol. Soc. America Bull., v. 67, p. 1700.

Griffitts, W. R., and Overstreet, W. C., 1952, Granitic rocks of the western Carolina Piedmont: Am. Jour. Sci., v. 250, p. 777-789.

Hée, Arlette, and Flesch, Louis, 1957, Age absolu apparent des zircon d'Espaly [Haute-Loire]: Acad. sci. [Paris] Comptes rendus, v. 244, no. 13, p. 1796-1798.

Herzog, L. F., and others, 1956, Rb-Sr analysis and age determination by mass spectrometry and related studies [abs.] :-Internat. Geol. Cong., 20th, Mexico Gity. Resumenes de los trabajos presentados, p. 217-218.

Hinds, N. E. A., 1934, The Jurassic age of the last granitoid intrusives in the Klamath Mountains and Sierra Nevada, California: Am. Jour. Sci., 5th ser., v. 27, p. 182-192.

Holland, H. D., and Gottfried, David, 1955, The effect of nuclear radiation on the structure of zircon: Acta Cryst., v. 8, p. 291-300.

Holmes, Arthur, 1947, The construction of a geological time scale: Geol. Soc. Glasgow Trans., v. 21, pt. 1, p. 117-152.

1948a, Monazite as a geological timekeeper: Royal Soc. Edinburgh Proc., v. 63, pt. 2, p. 115-124.

- 1948b, The oldest known minerals and rocks: Geol. Soc. Edinburgh Trans., v. 14, pt. 2, p. 176-194.

1954, The oldest dated minerals of the Rhodesian Shield: Nature, $\nabla$. 173, p. 612-614. 
Hurley, P. M., 1956, Direct radiometric measurement by gamma-ray scintillation spectrometer; pt. 1: Uranium and thorium series in equilibrium; pt. 2: Uranium, thorium, and potassium in common rocks: Geol. Soc. America Bull., v. 67, p. 395-404, 405-411.

Hurley, P. M., and Fairbairn, H. W., 1953, Radiation damage in zircon-a possible age method: Geol. Soc. America Bull., v. 64, p. 659-673.

1957, Abundance and distribution of uranium and thorium in zircon, sphene, apatite, epidote, and monazite in granitic rocks: Am. Geophys. Union Trans., v. 38, p. 939-944.

Hurley, P. M., Pinson, W. H., Fairbairn, H. W., and Cormier, R. F., 1957, Comparison of $\mathrm{A}^{40} / \mathrm{K}^{40}$ and $\mathrm{Sr}^{37} / \mathrm{Rb}^{87}$ ages on biotite [abs.] : Am. Geophys. Union Trans., $v .38$, p. 396.

Hutchinson, R. M., Jaffe, H. W., and Gottfried, David, 1954, Magmatic trends. and absolute age determinations of Precambrian intrusives of central Texas [abs.] : Geol. Soc. America Bull., v. 65, p. 1266.

Jaffe, H. W., 1955, Precambrian monazite and zircon from the Mountain Pass rare earth district, San Bernardino County, California : Geol. Soc. America. Bull., v. 66, p. 1247-1256.

Jaffe, H. W., Gottfried, David, Waring, C. L., and Worthing, H. W., 1959, Lead-alpha age determinations of accessory minerals of igneous rocks (19531957) : U.S. Geol. Survey Bull. 1097-B.

Kaye, C. A., 1957, Notes on the structural geology of Puerto Rico: Geol. Soc. America Bull., v. 68, p. 103-118.

Keevil, N. B., 1939, The calculation of geologic age: Am. Jour. Sci., v. 237, p. 195-214.

Keevil, N. B., and Grasham, W. E., 1943, Theory of alpha ray counting from solid sources: Canadian Jour. Research, v. 21, p. 21-36.

Knopf, Adolph, 1956, Argon-potassium determination of the age of the Boulder bathylith, Montana: Am. Jour. Sci., v. 254, p. 744-745.

1957, The Boulder bathylith of Montana: Am. Jour. Sci., v. 255, p. 81-103.

Kostyleva, E. E., 1946, On metamictic disintegration of the zircon group of minerals, in Problems of mineralogy, geochemistry, and petrography (translated by Taisia Stadnichenko) ; U.S. Geol. Survey TEI-369, 16 p., issued by U.S. Atomic Energy Comm. Tech. Inf. Service Ext., Oak Ridge, Tenn.

Kulp, J. L., Bate, G. L., and Broecker, W. S., 1954, Present status of the lead method of age determination: Am. Jour. Sci., v. 252, p. 345-365.

Kulp, J. L., and Eckelman, W. R., 1957, Discordant $\mathrm{U} / \mathrm{Pb}$ ages and mineral type: Am. Mineralogist, v. 42, p. 154-164.

Larsen, E. S., Jr., 1945, Time required for the crystallization of the great batholith of southern and Lower California: Am Jour. Sci., v. 243-A, Daly Volume, p. 369-416.

_ 1948, Batholith and associated rocks of Corona, Elsinore, and San Luis Rey quadrangles, southern California: Geol. Soc. America Mem. 29, 182 p.

Larsen, E. S., Jr., and Cross, Whitman, 1956, Geology and petrology of the San Juan region, southwestern Colorado: U.S. Geol. Survey Prof. Paper 258, $303 \mathrm{p} ., 4 \mathrm{pls}$.

Larsen, W. S., Jr., Gottfried, David, Jaffe, H. W., and Waring, C. L., 1958, Leadalpha age determinations of the Mesozoic batholiths of western North America : U.S. Geol. Survey Bull. 1070-B, p. 35-62, pls. 5-6.

Larsen, E. S., Jr., and Keevil, N. B, 1947, Radioactivity of the rocks of the batholith of southern California: Geol. Soc. America Bull., v. 58, p. 483-494. 
Larsen, E. S., Jr., Keevil, N. B., and Harrison, H. C., 1952, Method for determining the age of igneous rocks using the accessory minerals: Geol. Soc. America Bull., v. 63, p. 1045-1052.

Larsen, E. S., Jr., and Schmidt, R. G., 1958, A reconnaissance of the Idaho batholith and comparison with the southern California batholith: U.S. Geol. Survey Bull. 1070-A, p. 1-33, pl. 1.

Larsen, E. S., Jr., Waring, C. L., and Berman, Joseph, 1953, Zoned zircon from Oklahoma : Am. Mineralogist, v. 38, p. 1118-1125.

Larsen, L. H, and Poldervaart, Arie, 1957, Measurement and distribution of zircon in some granite rocks of magmatic origin: Mineralog. Mag., v. 31, no. 238 , p. 544-564.

Lyons, J. B., Jaffe, H. W., Gottfried, David, and Waring, C. L., 1957, Lead-alpha ages of some New Hampshire granites: Am. Jour. Sci., v. 255, p. 527-546.

Mertie, J. B., Jr., 1953, Monazite deposits of the southeastern Atlantic States: U.S. Geol. Survey Circ. 237, 31 p.

1937, The Yukon-Tanana Region, Alaska: U.S. Geol. Survey Bull. 872, 276 p. 15 pls.

Miller, W. J., 1946, Crystalline rocks of southern California: Geol. Soc. America Bull., v. 57, p. 457-540.

Moorhouse, W. W., 1956, The paragenesis of accessory minerals : Econ. Geology, v. 51, p. 248-262.

Nier, A. O., 1939, The isotopic constitution of radiogenic leads and measurements of geologic time, pt. 2 : Phys. Rev., v. 55, p. 153-163.

Nogami, H. H., and Hurley, P. M., 1948, The absorption factor in counting alpha rays from thick mineral sources: Am. Geophys. Union Trans., v. 29, p. 335340.

Olson, J. C., Shawe, D. R., Pray, L. C., and Sharp, W. N., 1954, Rare-earth mineral deposits of the Mountain Pass district, San Bernardino County, Calif.: U.S. Geol. Survey Prof. Paper 261, 75 p., 13 pls.

Palache, C., Berman, H., and Frondel, C., 1951, Dana's system of mineralogy, 7th ed., v. 2 : New York, John Wiley and Sons, Inc.

Phemister, T. C., 1957, The Copper Cliff rhyolite in McKim Township, District of Sudbury: Ontario Dept. Mines, 65th Ann. Rept., v. 65, pt. 3, (1956), p. 91-116.

Pinson, W. H., Jr., 1957, Comparison of $\mathrm{K} / \mathrm{A}$ and $\mathrm{Rb} / \mathrm{Sr}$ ages of three Precambrian rocks: Mass. Inst. Technology, 4th Ann. Prog. Rept. NYO-3937, p. $39-43$.

Poldervaart, Arie, 1956, Zircon in rocks, pt. 2, Igneous rocks : Am. Jour. Sci., v. 254, p. 521-554.

Powell, R. A., and Kinser, O. A., 1958, Dithizone method for determination of lead in monazite: Anal. Chemistry, v. 30, no. 6, p. 1139-1141.

Quinn, A. W., Jaffe, H. W., Smith, W. L., and Waring, C. L., 1957, Lead-alpha ages of Rhode Island granitic rocks compared to their geologic ages: Am. Jour. Sci., v. 255, p. 547-560.

Rankama, Kalerro, and Sahama, Th. G., 1950, Geochemistry: Chicago, Univ. Chicago Press, 912 p.

Reynolds, J. H., 1957, Oomparative study of argon content and argon diffusion in mica and feldspar: Geochim. et Cosmochim. Acta, v. 12, p. 117-184.

Roques, Maurice, 1956, Détermination de l'âge absolu du granite carbonifère du Mayet de montagne [Allier]: Acad. Sci [Paris], Comptes rendus, v. 242, p. 528-530.

Ross, O. P., 1952, The eastern front of the Bitterroot Range, Montana : U.S. Geol. Survey Bull. 974-E, p. 135-175, pl. 4. 
Ross, C. P. and Forrester, J. D., 1947, Geologic map of the State of Idaho: U.S. Geol. Survey and Idaho Bur. Mines and Geology.

Sahama, Th. G., 1946, On the chemistry of the mineral titanite: Finland, Comm. Geol. Bull. 138, p. 88-120.

Saillard, Nicole, Scheibling, M. Gaston, and Hée, Arlette, 1957, Sur la détermination de la teneur en plomb des zircons par une méthod spectrographique: Acad. Sci [Paris], Comptes rendus, v. 244, no. 5, p. 609-611.

Sandell, E. B., 1950, Colorimetric determination of traces of metals, in Chemical analysis, v. 3, $2 \mathrm{~d}$ ed. : New York, Interscience Publishers, Inc.

Senfitle, F. E., 1951, Apparatus for separation of mineral grains: Am. Minenalogist, , v. 36, p. 910-912.

Silver, L. T., Stehli, F. G., and Allen, C. R., 1956, Lower Cretaceous prebatholithic rocks of northern Baja Oalifornia, Mexico. [abs.] : Internat. Geol. Cong., 20th, Mexico City, Resumenes de los trabajos presentados, p. 30.

Stearns, C. E., 1953, Tertiary geology of the Galisteo-Tonque area, New Mexico: Geol. Soc. America Bull., v. 64, p. 459-507.

Stieff, L. R., and Stern, T. W., 1956, Interpretation of the discordant age sequence of uranium ores, in Contributions to the geology of uranium and thorium by the U.S. Geol. Survey and Atomic Energy Comm. for the United Nations Internat. Conf. on peaceful uses of atomic energy, Geneva, Switzerland, 1955 : U.S. Geol. Survey Prof. Paper 300, p. 549-555.

Taylor, O. H., 1915, Granites of Oklahoma: Oklahoma Geol. Survey Bull. 20, $108 \mathrm{p}$.

Tilton, G. R., 1956, The interpretation of lead-age discrepancies by acid-washing experiments : Am. Geophys. Union Trans., v. 37, p. 244-230.

Tilton, G. R., Davis, G. L., Wetherill, G. W., and Aldrich, L. T., 1957, Isatopic ages of zircon from granites and pegmatites: Am. Geophys. Union Trans., v. 38, p. 360-371.

Tilton, G. R., and Nicolaysen, L. O., 1957, The use of monazites for age determination : Geochim. et Cosmochim. Acta, v. 11, p. 28-40.

Tilton, G. R. and others, 1955, Isotopic composition and distribution of lead, uranium, and thorium in a Precambrian granite: Geol. Soc. America Bull., v. 66, p. 1131-1148.

Wadia, D. N., and Fernando, L. J. D., 1944, Ilmenite, monazite, and zircon (sessional paper 6 of 1926, revised) Gems and semi-precious stones of Ceylon: Ceylon, Dept. Mineralogy, Recs., Prof. Paper 2, p. 13-44.

Waring, C. L., and Worthing, Helen W., 1953, A spectrographic method for the determination of trace amounts of lead in zircon and other minerals: Am. Mineralogist, v. 38, p. 827-833.

Waters, A. C., 1955, Volcanic rocks and the tectonic cycle, in Poldervaart, Arie, ed., Crust of the earth: Geol. Soc. America Spec. Paper 62, p. 703-722.

Webber, G. R., Hurley, P. M., and Fairbairn, H. W., 1956, Relative ages of eastern Massachusetts granites by total lead ratios in zircon: Am. Jour. Sci., v. 254, p. 574-583.

Webster, R. K., Morgan, J. W., and Smales, A. A., 1957, Some recent Harwell analytical work on geochemistry: Am. Geophys. Union Trans., v. 38, p. 543-546.

Wedepohl, Karl Hans, 1956, Untersuchungen zur Geochemie des Bleis : Geochim. et Cosmochim. Acta, v. 10, p. 69-148.

Wetherill, G. W., Aldrich, L. T., and Davis, G. L., $1955, A^{40} / K^{40}$ ratios of feldspars and micas from the same rock: Geochim. et Cosmochim. Acta, v. 8, p 171-172. 
Wetherill, G. W., Davis, G. L., and Aldrich, L. T., 1957, Age measurements on rocks north of Lake Huron [abs.] : Am. Geophys. Union Trans., v. 38, p. 412.

Wetherill, G. W., and others, 1956, Decay constants of $\mathbf{K}^{40}$ as determined by the radiogenic argon content of potassium minerals: Phys. Rev., v. 103, p. 987-989.

Woodford, A. O., and Harriss, T. F., 1938, Geological reconnaissance across Sierra San Pedro Martir, Baja, California: Geol. Soc. America Bull., v. 49, p. 1297-1336.

Woyski, M. S., 1949, Intrusives of central Minnesota: Geol. Soc. America Bull., v. 60, p. 999-1016.

Youden, W. J., 1951, Statistical methods for chemists: New York, John Wiley and Sons, Inc., $128 \mathrm{p}$. 



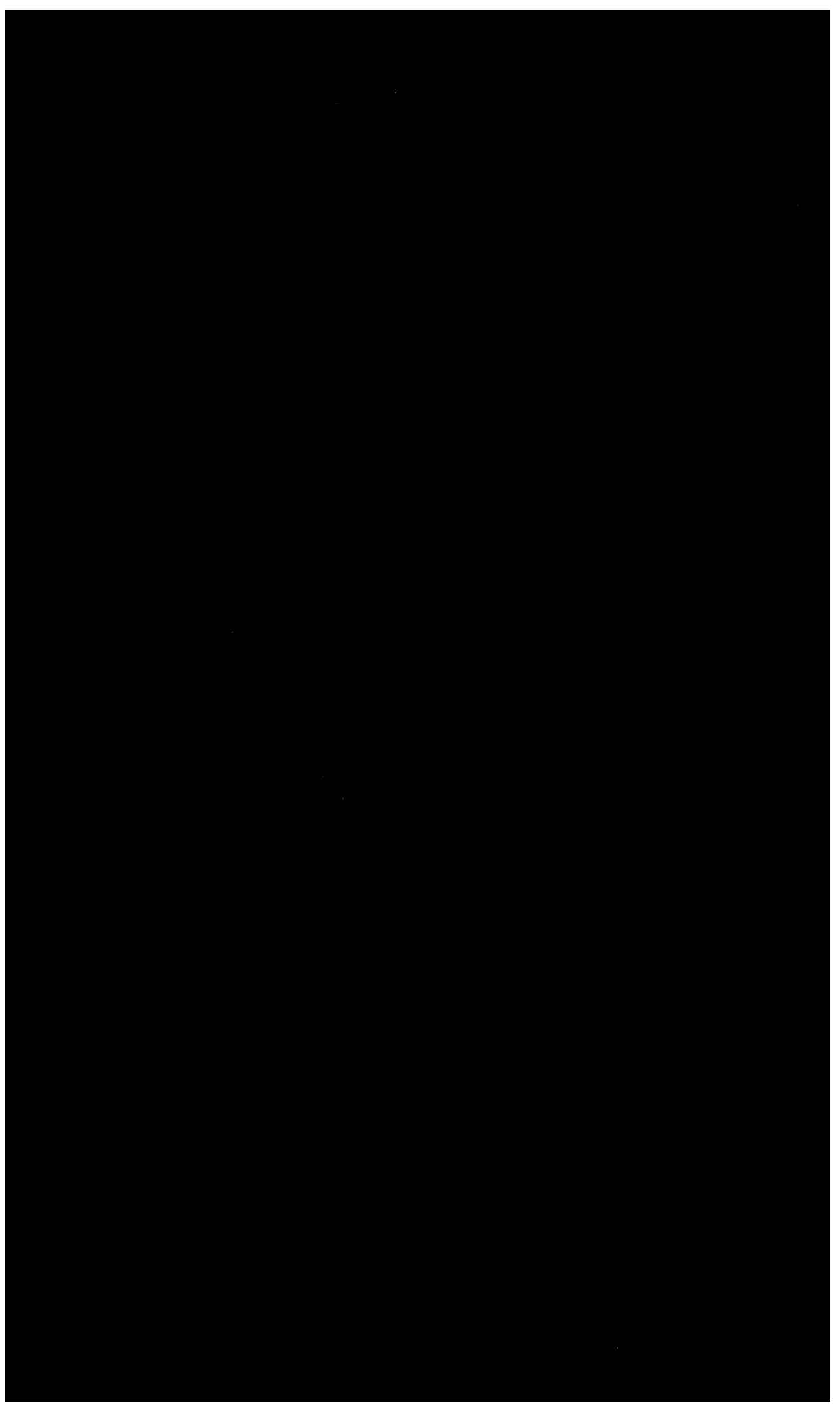




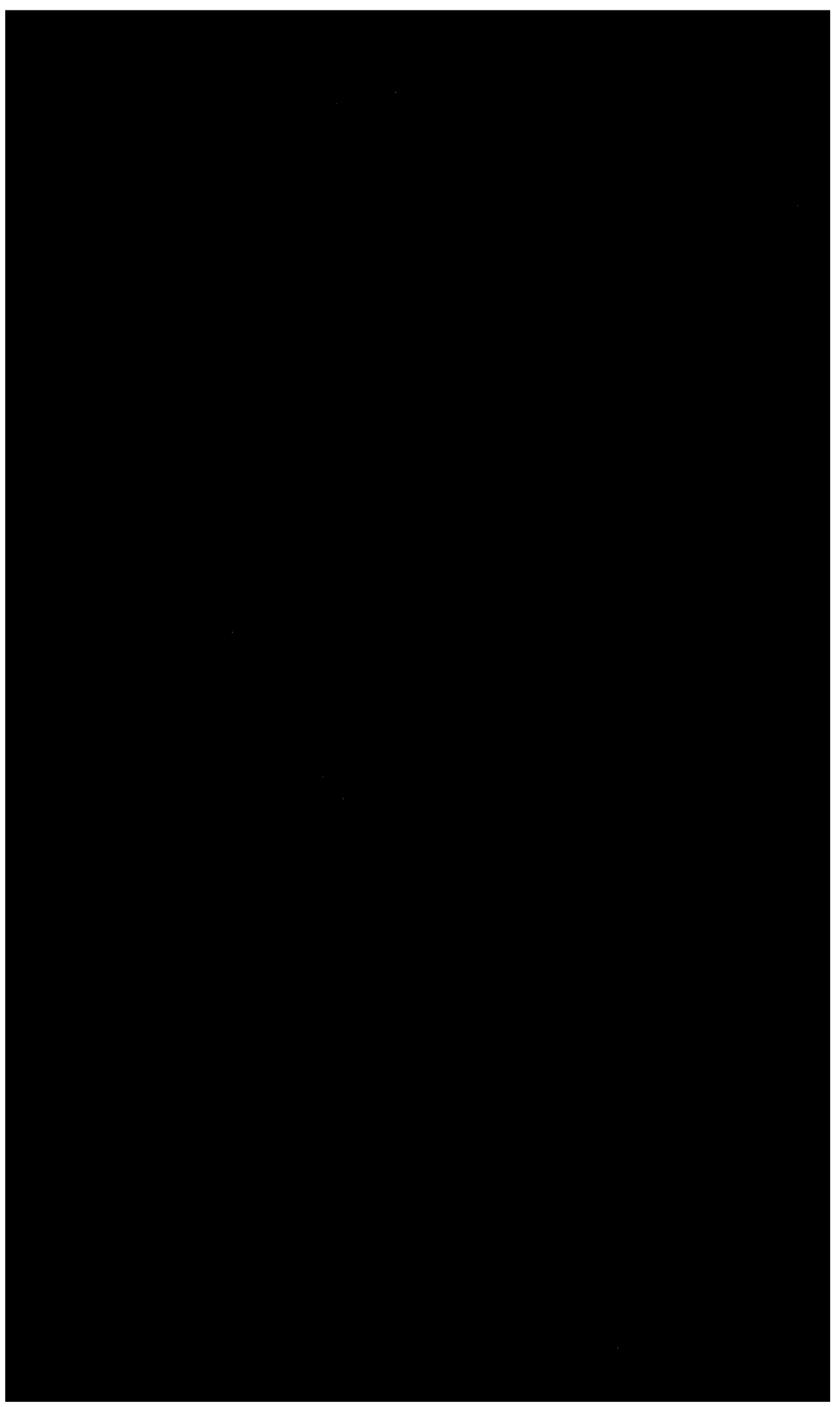

